$\frac{244}{9.24 .80} 1 \times 0$

pr. 176 ar.

ORNL/TM-6252

\title{
Summary of the Development of Open-Cycle Gas Turbine-Steam Cycles
}

\author{
M. E. Lackey \\ A. S. Thompson
}

Fossil

Enengy

Phogram

OPERATED BY

UNION CARBIDE CORPORATION FOR THE UNITED STATES DEPARTMENT OF ENERGY 


\section{DISCLAIMER}

This report was prepared as an account of work sponsored by an agency of the United States Government. Neither the United States Government nor any agency Thereof, nor any of their employees, makes any warranty, express or implied, or assumes any legal liability or responsibility for the accuracy, completeness, or usefulness of any information, apparatus, product, or process disclosed, or represents that its use would not infringe privately owned rights. Reference herein to any specific commercial product, process, or service by trade name, trademark, manufacturer, or otherwise does not necessarily constitute or imply its endorsement, recommendation, or favoring by the United States Government or any agency thereof. The views and opinions of authors expressed herein do not necessarily state or reflect those of the United States Government or any agency thereof. 


\section{DISCLAIMER}

Portions of this document may be illegible in electronic image products. Images are produced from the best available original document. 


\section{Printed in the Uniter States of Amcrica. Available from}

National Technical Information Service

\section{U.S. Department of Commerce}

5285 Pnrt Royal Road, Epringfield, Viryinla 22161

NTIS price codes-Printed Copy: A04; Microfiche A01

This report was prepared as an account of work sponsored by an agency of the United States Government. Neither the United States Government nor any agency thereof, nor any of their employees, makes any warranty, express or implied, or assumes any legal liability or responsibility for the accuracy, completeness, or usefulness of any information, apparatus, product, or process disclosed, or represents that its use would not infringe privately owned rights. Reference herein to any specific commercial product, process, or service by trade name, trademark, manufacturer, nr otherwiso, dосз not liecessarily constitute or imply its endorsement, recommendation, or favoring by the United States Government or any agency thereof. The views and opinions of authors expressed herein do not necessarily state $n r$ reflect those of the United Slales Government or any agenny thoroof. 

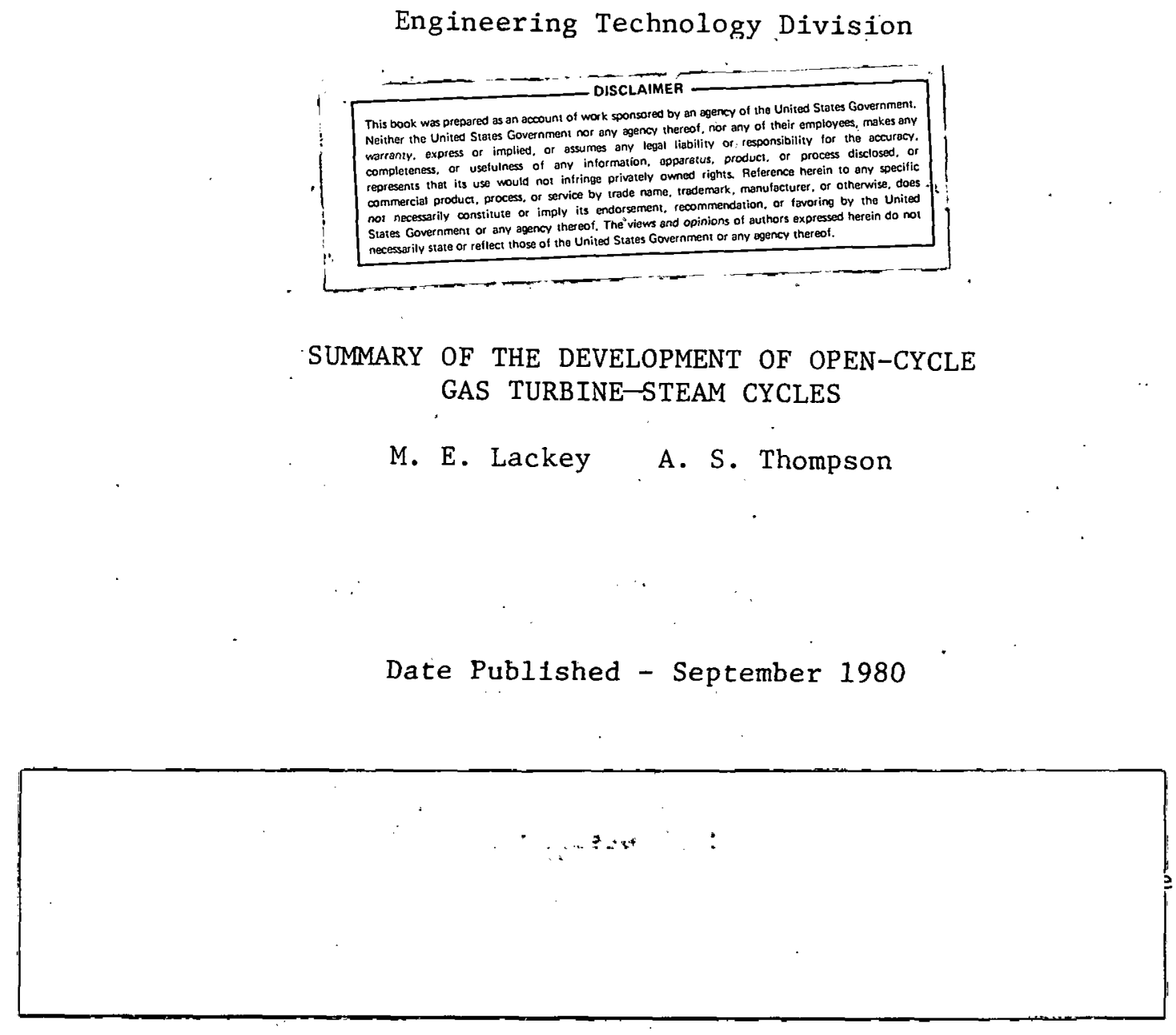

Prepared by the

OAK RIDGE NATIONAL LABORATORY

Oak Ridge, Tennessee 37830

operated by

UNION CARBIDE CORPORATION

for the

DEPARTMENT OF ENF.RGY 
This is one of a set of companion reports evaluating and comparing advanced energy conversion systems on the basis of their research and development experience. The reports are listed below.

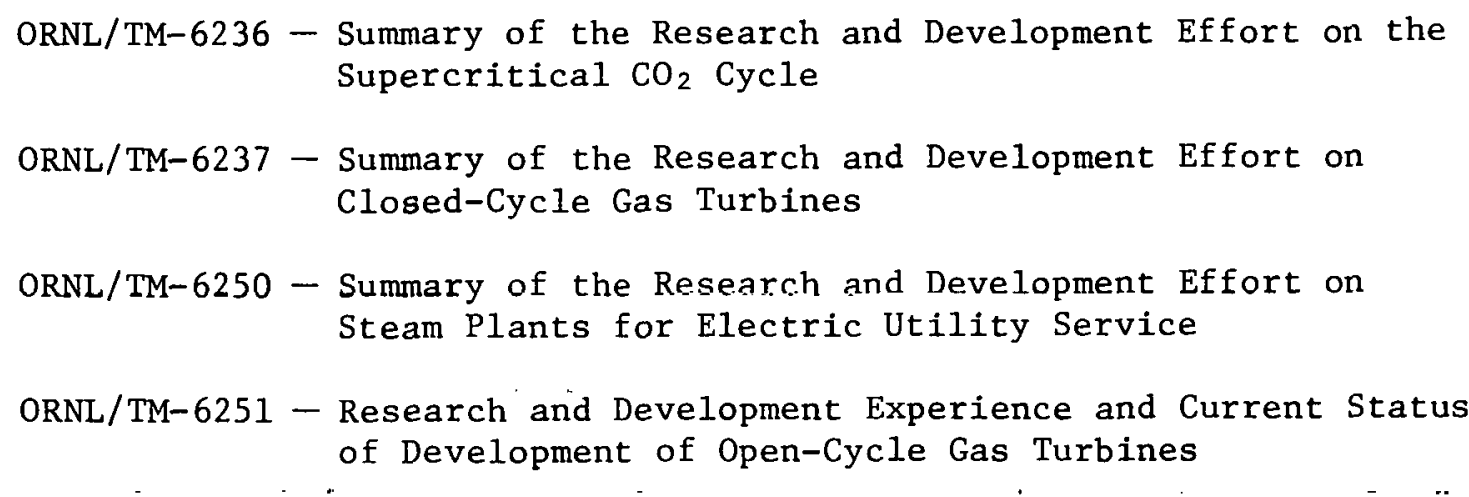

ORNL/TM-6252 - Summary of the Development of Open-Cycle Gas TurbineSteam Cycles

ORNL/TM-6253 - Summary of the Research and Development Effort on Open-Cycle Coal-Fired Gas Turbines

ORNL/TM-6254 - Summary of Research and Development Effort on Air and Water Cooling of Gas Turbine Blades

ORNL/TM-6255 - Summary of the Research and Development Effort on Ceramic Gas Turbines

ORNL/TM-6256 - Summary of the Research and Development Effort on Alkal1 Metal Vapor Cycles

ORNL/TM-6257 - Summary of the Research and Development Effort on Open-Cycle MHD Systems

ORNL/TM-6258 - Summary of the Research and Development Effort on

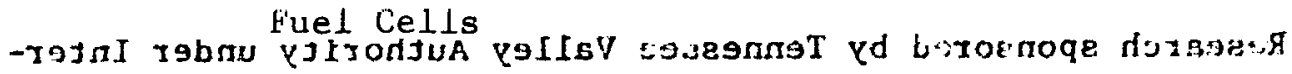

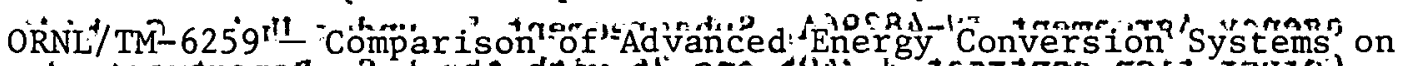

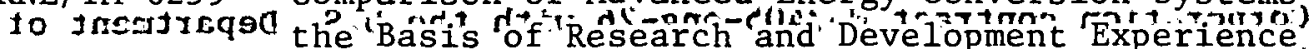
- y.yisnt

ORNL/TM-6383 - Comparison of Advanced Energy Conversion Systems on the Basis of Research and Development Experience. Executive Summary Report 
CONTENTS

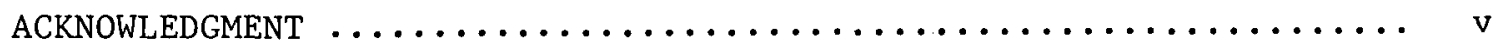

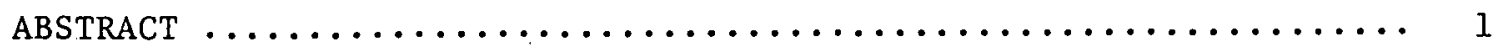

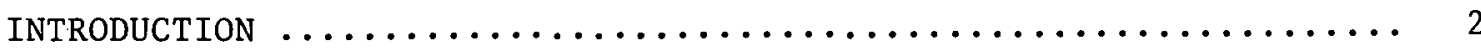

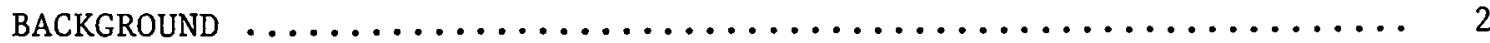

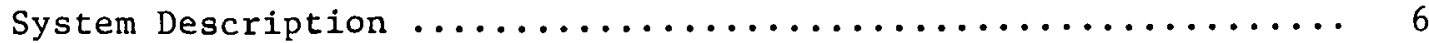

Gas turbine with a waste heat recovery boiler ........... 6

Integrated coal gasification and combined-cycle

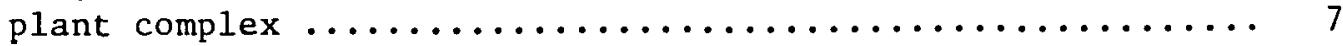

Basic performance characteristics .................... 9

Combined cycle with the turbine air heated by tubes

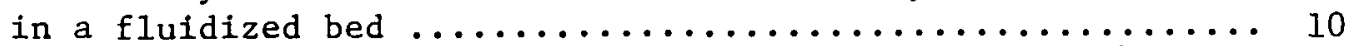

Summary of Program Costs and Running Time .............. 10

RECOMMENDED DEVELOPMENT PROGRAM $\ldots \ldots \ldots \ldots \ldots \ldots \ldots \ldots \ldots \ldots \ldots \ldots$

PRINCIPAL PROBLEMS AND PARAMETERS $\ldots \ldots \ldots \ldots \ldots \ldots \ldots \ldots \ldots \ldots \ldots \ldots$

Matching the Steam Cycle to the Gas Turbine Cycle .......... 12

Practicable Gas Turbine Inlet Temperatures .............. 16

Efficient Utilization of Energy in Coal $\ldots \ldots \ldots \ldots \ldots \ldots \ldots \ldots$

Effects of coal conversion process efficiency

and heat recovery temperature ...................... 17

Characteristics of typical coal gasification process ...... 20

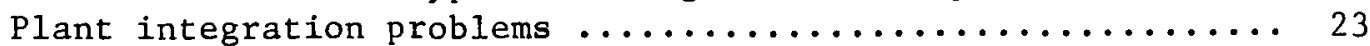

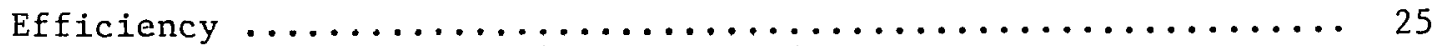

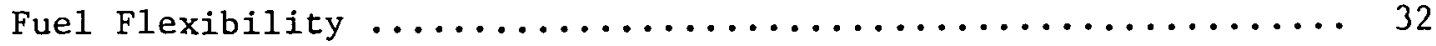

Reliability and Availability $\ldots \ldots \ldots \ldots \ldots \ldots \ldots \ldots \ldots \ldots \ldots \ldots \ldots \ldots \ldots \ldots$

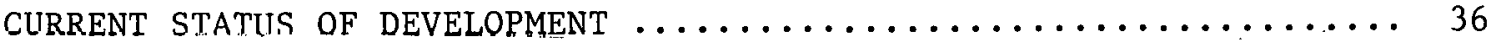

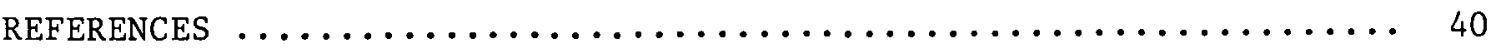

APPENDIX A. COMBINED-CYCLE POWER PLANT INSTALLATIONS $\ldots \ldots \ldots \ldots \ldots 45$

APPENDIX B. POTENTIAL FOR FUTURE DEVELOPMENT $\ldots \ldots \ldots \ldots \ldots \ldots \ldots \ldots$ 
THIS PAGE

\section{WAS INTENTIONALLY \\ LEFT BLANK}




\section{ACKNOWLEDGMENT}

A special debt of appreciation is owed S. Alpert, R. Duncan, and R. Jaffee of EPRI, R. W. Foster-Pegg of Westinghouse, and H. Hartman, M. Myers, J. P. Nichols, and G. Samuels of ORNL for the invaluable information, papers, and reports that they kindly supplied. In addition, special thanks are due R. W. Foster-Pegg, M. L. Myers, and G. Samuels for their detailed criticisms and comments following their reviews of the draft report. 


\title{
SUMMARY OF THE DEVELOPMENT OF OPEN-CYCLE GAS TURBINE-STEAM CYCLES
}

\author{
M. E. Lackey A. S. Thompson
}

ABSTRACT

Combined-cycle plants employing gas turbine cycles superimposed on conventional steam plants are well developed. Nearly 200 units are operating in the U.S. on clean fuels (natural gas or distillate fuel oils) and giving overall thermal efficiencies as high as $42 \%$. Future plants will have to use coal or coalderived fuels, and this presents problems because gas turbines are very sensitive to particulates and contaminants in the fuel such as sulfur, potassium, lead, etc. If clean liquid or highBtu gaseous fuels are made from coal, it appears that the conversion efficiency will be no more than $67 \%$. Thus, the overall efficiency of utilization of coal would be less than if it were burned in a conventional steam plant unless the permissible gas turbine inlet temperature can be increased to $21500^{\circ} \mathrm{C}\left(2732^{\circ} \mathrm{F}\right)$. Coupling a combined-cycle power plant directly to a low-Btu coal gasifier increases the fuel conversion efficiency and permits salvaging waste heat from the gasifier for feedwater heating in the steam cycle. By using a gas turbine inlet temperature of $1315^{\circ} \mathrm{C}\left(2400^{\circ} \mathrm{F}\right)$, well above the current maximum of $\sim 1040^{\circ} \mathrm{C}\left(1904^{\circ} \mathrm{F}\right)$, an overall efficiency of $\sim 40 \%$ has been estimated for the integrated plant. However, as discussed in companion reports, it is doubtful that operation with gas turbine inlet temperatures above $1100^{\circ} \mathrm{C}\left(2012^{\circ} \mathrm{F}\right)$ will prove practicable in base-load plants. Recent difficulties with $\mathrm{Fe}_{2} \mathrm{O}_{3}$ deposits on air-cooled turbine blades operating at temperatures above $1100^{\circ} \mathrm{C}\left(2012^{\circ} \mathrm{F}^{\prime}\right)$ with on $1 \mathrm{y} 0.06 \mathrm{ppill}$ of particulates in the air stream make it questionable whether it will be practicable to operate a gas turbine coupled to a coal gasifier with turbine inlet temperatures above $\sim 1100^{\circ} \mathrm{C}\left(2012^{\circ} \mathrm{F}\right)$. The inherent brittleness of ceramics makes ceramic turbines subject to failure from thermal stresses while the high heat flux to water-cooled blades coupled with the intricacy of the water cooling passages required make that approach a doubtful prospect for $1315^{\circ} \mathrm{C}\left(2400^{\circ} \mathrm{F}\right)$ gas turbines. 


\section{INTRODUCTION}

This is one of a series of topical reports summarizing the research and development ( $R \& D$ ) effort on various phases of advanced power conversion systems. ${ }^{1-11}$ This report is especially concerned with the application of the gas turbine in combined-cycle electric utility plants.

The first portion of this report presents a background history of combined-cycle utility plants up to 1977, and the next section discusses recommended development programs and priorities. This is followed by a presentation of the principal problem areas, performance parameters, and figures of merit characteristic of the system to provide perspective. on the various problems. The principal parameters and figures of merit include such quantities as the operating life, turbine inlet temperature, cycle efficiency, etc. Subsequent sections summarize the current status and experience in combined-cycle installations.

This work was carried out at the request of the Office of Program Planning and Analysis, Fossil Energy Program, DOE, with funds provided for a general appraisal of advanced fossil energy systems.

\section{BACKGROUND}

A combined cycle is defined as a combination of several cycles which could each operate independently. The several cycles operate with different working fluids or else they would be classified as compound cycles. Commercial applications of combined cycles have included diesel-steam, mercury-steam, and gas turbine-steam. Other combined cycles, such as steam-organic fluid, helium-ammonia, alkali metal-steam, MHD-steam, etc., have been proposed for commercial operation.

The peak temperature in the mercury-steam cycle of the $1930^{\prime} \mathrm{s}$ was limited to $482^{\circ} \mathrm{C}\left(900^{\circ} \mathrm{F}\right)$ by materials problems and hence lost its efficiency advantage when it became possible to build $540^{\circ} \mathrm{C}\left(1000^{\circ} \mathrm{F}\right)$ steam plants. The relatively small generating capacity per unit and the low temperature of the steam produced by the diesel-steam cycle limits its 
use to special applications. The combined gas turbine-steam cycle has been adapted to serve the large utility producer as well as industrial plants that require both electricity and process steam production. As in simple open-cycle gas turbines, the thermal efficiency depends heavily on the gas turbine component efficiency. Many early studies yielded high estimated thermal efficiencies for gas turbine cycles, yet in cases in which a plant was actually built the measured thermal efficiency often fell far below the original estimate. In fact, in the first gas turbine ever built (designed by Stolze in 1872), the compressor power input exceeded the turbine power output. ${ }^{12}$ It was not until three decades later that a net useful power output was obtained from a continuous combustion gas turbine built and tested by Charles Lemale and Rene Armengaud. ${ }^{3}$ However, the thermal efficiency was only $3 \%$.

The first commercial application of the gas turbine (which incidentally used an axial compressor) occurred in 1932 with the advent of the Velox pressurized boiler developed by Brown, Boveri and Company of Switzerland. ${ }^{4}$ The Velox boiler is pressurized by a compressor driven by a gas turbine with the hot flue gas from the boiler. This was the first commercial use of the combined gas turbine-steam cycle. Over 100 units have been built for commercial service and 34 for U.S. Navy destroyers, all of which were for oil or gas firing. ${ }^{15}$ Owing to the low component efficiencies (compressor $73 \%$, turbine $83 \%$ ) and the relatively low turbine inlet temperature of 450 to $510^{\circ} \mathrm{C}$ in these early units, the turbine output was only sufficient to power the combustion air compressor. A somewhat similar application of the gas turbine compressor drive system was used in the Houdry catalytic-cracking process in 1936 by the Sun Oil Company at its Marcus Hook, Pennsylvania, plant. ${ }^{16}$ This installation not only used the turbine to supply the compressor drive power, but also used the heat in the turbine exhaust to raise process steam; there was sufficient excess power from the turbine over the compressor power requirement to drive an electric generator.

For electric utility service the first power station employing only gas turbines was developed in 1939 by the Escher Wyss Engineering Works in Zurich, Switzerland. ${ }^{17}$ This plant was a closed-cycle system employing 
regeneration and intercooling that produced $2000 \mathrm{~kW}(\mathrm{e})$ at a thermal efficiency of $31.6 \%$. In 1949, the Oklahoma Gas and Electric Company installed at their Belle Isle Station a 3500-kW(e) locomotive drive gas turbine in combination with an existing medium-pressure steam system. ${ }^{18,19}$ The overall plant cycle efficiency was increased from approximately $22 \%$ to $26 \%$ by the addition of the gas turbine.

The price advantage of coal and residual fuel oils used in conventional fossil fuel steam generators over the distillate fuel oil or natural gas required for high-temperature gas turbines did not favor the installation of gas turbine-steam combined-cycle power plants by utilities during the 1950's and 1960's. During the late 1960's and early 1970's, the demand for repowering existing plants, coupled with increased construction costs, led to a substantial demand for combined-cycle installations. The rate of installation of new units to give the current electrical utility power generation capacity of approximately 20,000 MW(e) is shown in Fig. 1.19-28 A tabulation of 103 combined cycle power plants with a total of 179 units that were in operation or on order as of June 1976 is given in Appendix A (Ref. 29).

Inspection of Fig. 1 shows the effects of the present shortage and high cost of high-grade fuels on the installation of gas turbine-steam combined cycles. There were orders for on 1 y two installations in $19 \% 6$ as compared to an average of 13 per year for the previous five years. The present fuel outlook indicates that, in the foreseeable future, coal will be the primary U.S. fossil fuel source for new central stations. 'lhe direct coal-fired gas turbine, as indicated in another report in this series, ${ }^{4}$ is not likely to prove practicable because of turbine blade erosion and deposits caused by flyash, but clean gaseous or liquid fuels' derived from coal offer promising possibilities for fueling gas turbine-steam cycles. Liquid and high-Btu gaseous fuels have the major advantage that they can be stored and transported, but if this course is taken the heat losses in the conversion process cannot be utilized for feedwater heating in the steam-electric plant to improve the overall efficiency of the conversion of the chemical energy in the coal into electrical energy. A higher overall energy conversion efficiency can be obtained by integrating a low-Btu coal gasification plant directly with a combined-cycle electric power plant. 


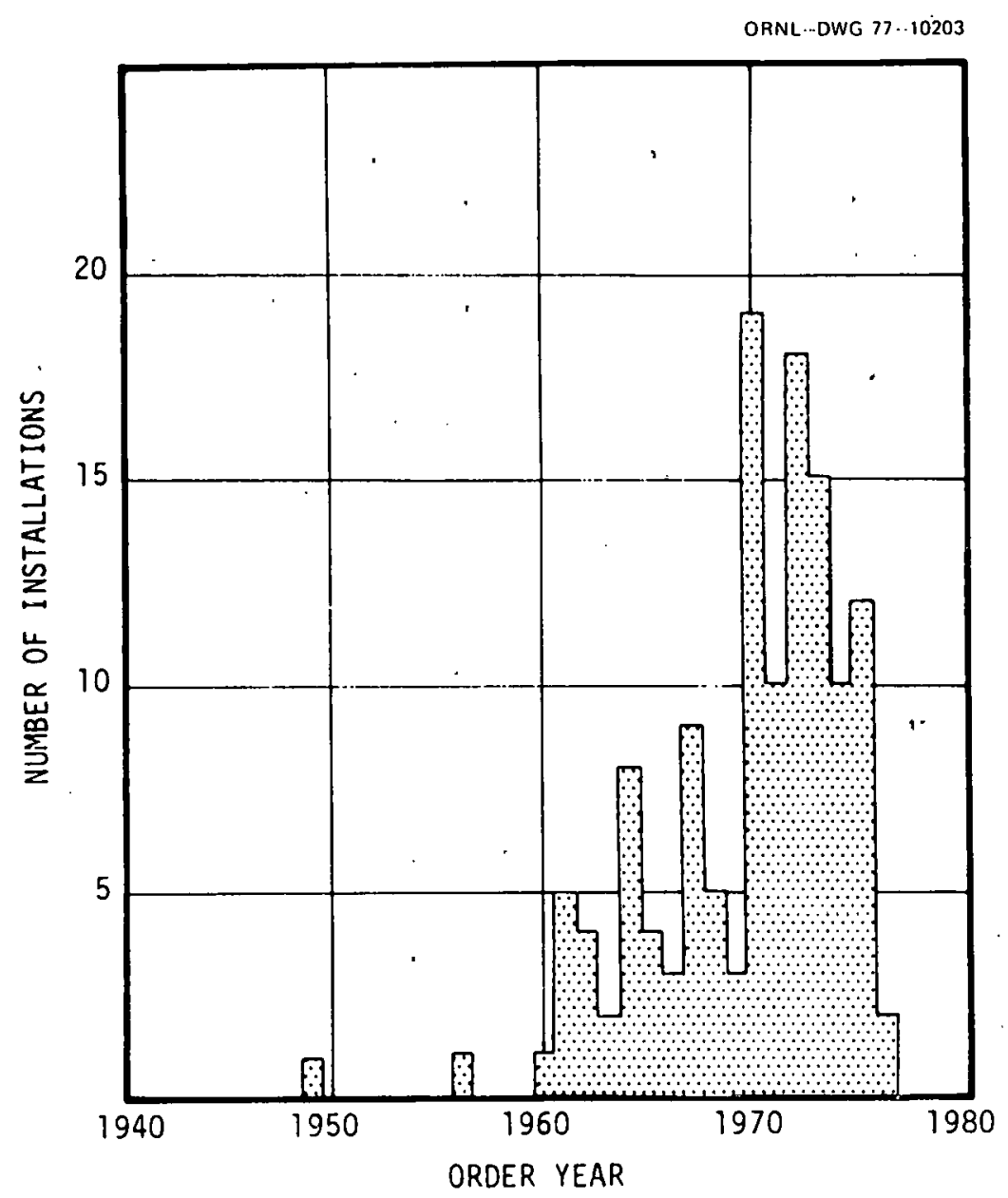

Fig. 1. Gas turbine-steam combined-cycle power plant installations for electric utility power generation (1949-1976).

Thus the most heavily funded approach currently entails coupling a coal-fueled gas turbine-steam cycle plant to a low-Btu coal gasification process. The latter should yield a fuel gas. with a sulfur content below approximately $0.2 \%$, so that no stack gas cleanup'will be required and a particulate content below approximately $1 \mathrm{ppm}$ so that turbine blade erosion and deposits will probably not be a problem with turbine inlet temperatures up to $\sim 1100^{\circ} \mathrm{C}\left(2012^{\circ} \mathrm{F}\right) .^{4}$ The problems of attaining this objective in the coal gasification process are treated in Refs. 30 to 32; a brief summary of the formidable problems involved is presented later in this report. 
System Description

The vast majority of the combined gas turbine-steam cycle plants built to date have been basically gas turbine installations with a waste heat recovery boiler in the turbine exhaust to drive a steam bottoming cycle. The peak steam temperature in such a system is limited to something less than the present upper value of $540^{\circ} \mathrm{C}$ unless the gas turbine inlet temperature is in the 1050 to $1100^{\circ} \mathrm{C}$ range. Base-load gas turhines operating in this temperature range represent thr upper reachee of the present state of the art of gas turbine development. For gas turbiues operating at lower inlet temperatures, modern steam t.emperatures can be attained by afterburning to raise the temperature of the turbine exhaust. A thermodynamic analysis of this approach, presented in Appendix B, shows that when an afterburner is employed and the gas turbine-steam system is designed to give the maximum work output per pound of air handled (which acts to reduce the capital cost of the installation), the system also yields the maximum thermal efficiency.

Gas turbine with a waste heat recovery boiler

A flowsheet for a simple oil- or gas-fired gas turbine with a heat recovery steam boiler and steam turbine bottoming cycle is shown in Fig. 2. This system has the advantage of simplicity, but the thermal efficiency is limited because the peak temperature in the steam cycle is relatively low - perhaps $430^{\circ} \mathrm{C}\left(806^{\circ} \mathrm{F}\right)$. Inasmuch as the gas turbine burner operatec with $\sim 300 \%$ excess air, an afterburner can be added between the turbine and the steam generator to increase the steam temperature. This increases the cycle efficiency to approximately $35 \%$ and also increases the output obtainable from the plant as a whole with a given size gas turbine. ${ }^{33}$ Thus this approach is commonly employed. The system performance could also be improved further by increasing the gas turbine inlet temperature, which gives a higher exhaust temperature and more favorable conditions in the steam cycle. Assuming advanced gas turbine designs with turbine inlet temperatures around $1370^{\circ} \mathrm{C}\left(2500^{\circ} \mathrm{F}\right)$, in the ECAS study it was estimated that a plant thermal efficiency of $\sim 47 \%$ might be attained. ${ }^{34-36}$ 


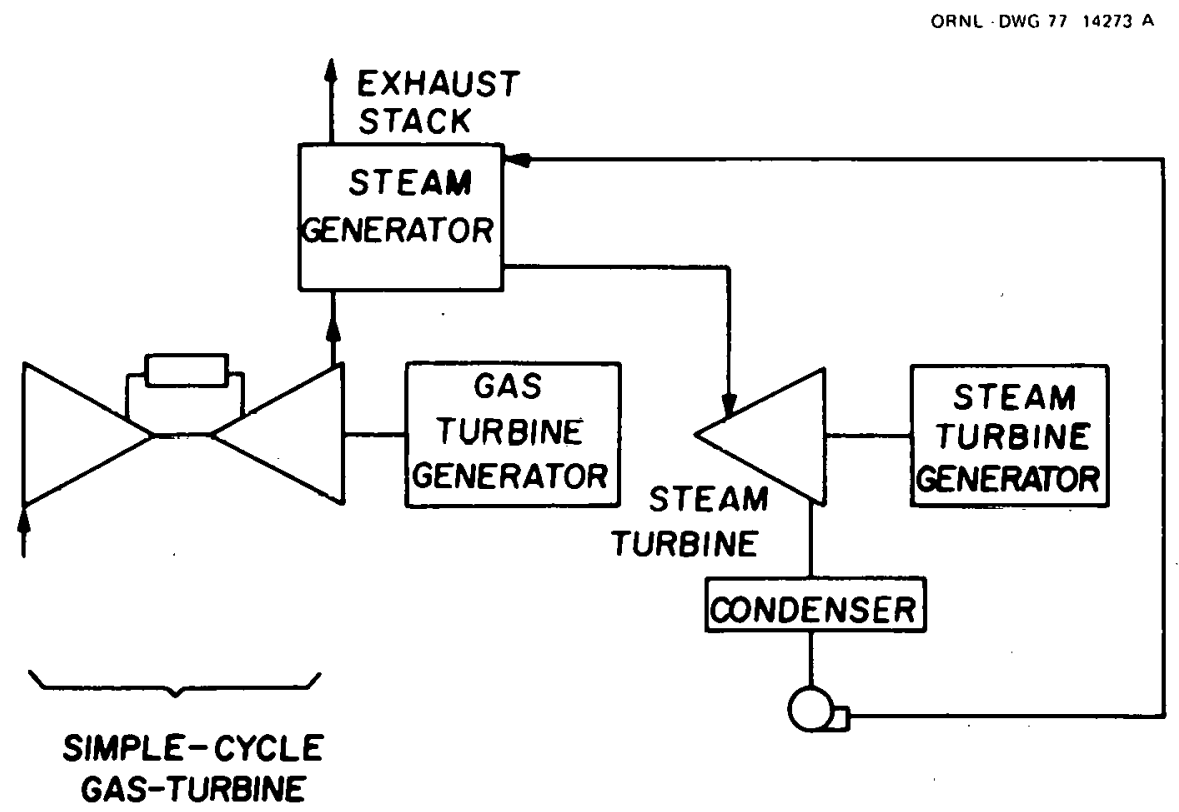
cycle.

Fig. 2. Flowsheet for a simple-cycle gas turbine-steam combined

Integrated coal gasification and combined-cycle plant complex

Figure 3 is a flowsheet for a plant in Lünen, Germany, the only combined-cycle system coupled to a coal gasification plant that has been built anywhere in the world to date. ${ }^{37}$ Note that the clean fuel gas is burned at a pressure of $10 \mathrm{~atm}$ to give a flame temperature of $1400^{\circ} \mathrm{C}$, and much of the heat of combustion is removed by the steam generator tubes so that the hot gas is fer to the gas turbine at $820^{\circ} \mathrm{C}$. The operation of this steam generator in the high-temperature and-pressure region allows the gas side temperature difference and the gas side heat transfer coefficient to be increased by factors of approximately 3 and 6 , respectively, over conventional steam generators for combined cycles such as that of Fig. 2 . This results in a major reduction in the surface area and the capital cost of the steam generator. The hot exhaust gas leaving the gas turbine at $400^{\circ} \mathrm{C}$ is used for feedwater heating. The Lurgi gasifiers are supplied with about $12 \%$ of the air compressor flow, which is boosted from 10 to 20 atm with a small compressor that is powered by an expansion turbine that recovers much of the pressure energy in the gas stream flowing from the gasifiers to the steam generator combustion chamber. 


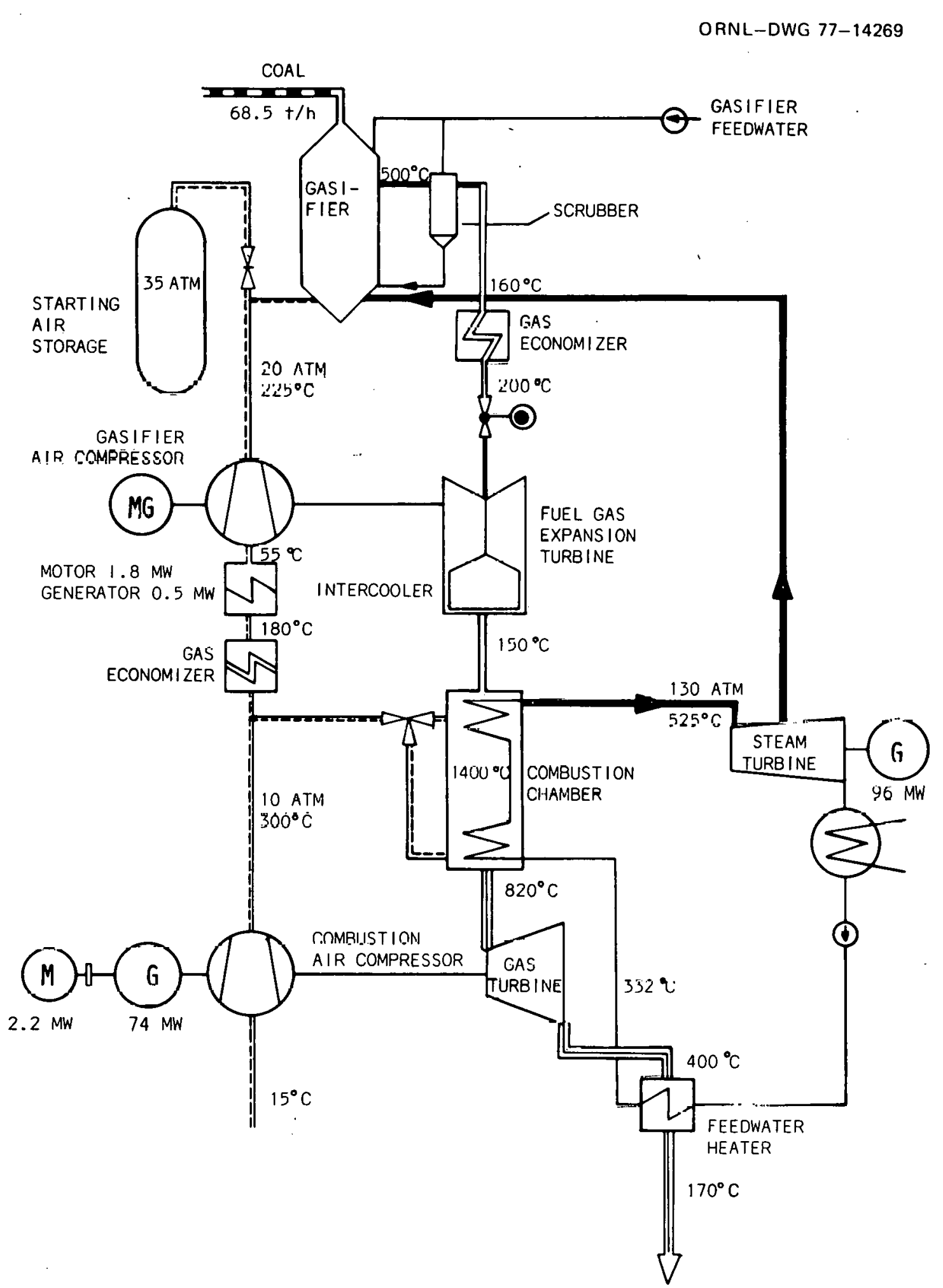

Fig. 3. Flowsheet for the integrated gasification combined-cycle Lünen plant. 
The plant as designed was expected to have an overall efficiency of $36.9 \%$, with approximately $40 \%$ of the electric power being generated by the gas turbine. ${ }^{37}$ Both the output of the gas turbine and the overall thermal efficiency could be increased if it were possible to employ a higher turbine inlet temperature; hence recent design studies in the U.S. (e.g., $\operatorname{ECAS}^{34,35}$ ) have assumed turbine inlet temperatures as high as $1370^{\circ} \mathrm{C}\left(2500^{\circ} \mathrm{F}\right)$, which is far higher than the $820^{\circ} \mathrm{C}$ turbine inlet temperature of the Lünen plant. This step was taken because, unless the gas turbine inlet temperature can be increased to over $1100^{\circ} \mathrm{C}\left(2000^{\circ} \mathrm{F}\right)$, the plant is not competitive with a conventional coal-f1red supercritical pressure steam plant with wet limestone stack gas scrubbers. Thus, a crucial question is the feasibility of achieving these markedly higher gas turbine inlet temperatures in a base-load plant with a fuel that probably will not be as clean as the natural gas or distillate fuel oils currently used in gas turbines.

\section{Basic performance characteristics}

Perhaps the most important advantage of conventional open-cycle gas turbines is that they can be started up quickly (in minutes) and respond rapidly to abrupt changes in the electrical load. If a steam bottoming cycle is added to one of these open-cycle gas turbines, one can still get good response to load changes but the startup time is greater. When a coal gasification plant is tightly coupled to a combined gas turbinesteam plant, the situation becomes completely different. The volumetric flow rate of the low-Btu gas is so great that it is impractical to store it; hence it must be used as rapidly as it is generated. The coal gasifiers have a high heat capacity and take a long time to heat up; the effectiveness of the coal gasification process is sensitive to pressure, temperature, and flow rate conditions, so that the gasifiers operate well over only a narrow range of conditions. Thus, plants of this type require 12 to $20 \mathrm{hr}$ to get on line from a cold start, are relatively inflexible, and hence can be employed only in base-load service. 
Combined cycle with the turbine air heated by tubes in a fluidized bed

The complexity and high capital cost of a coal gasifier and gas turbine erosion and deposits caused by ash in the coal led R. W. Foster-Pegg to propose a combined cycle in which the air from the compressor would be heated in a tube bank in a fluidized bed so that the gas turbine would operate on clean air. ${ }^{38}$ About $33 \%$ of the hot air leaving the turbine would then go to the fluidized bed as combustion air and the balance could be used to generate steam. This system looks especially attractive for industrial cogeneration applications.

\section{Summary of Program Costs and Running Time}

As in the development of the steam system, it is difficult to estimate the cost of the development of combined-cycle systems because the basic $R \& D$ costs have fallen on either conventional steam or conventional gas turbine systems. Thus, the incremental costs of the combined system have been written off against each commercial installation and are buried in capital and operating costs. However, the R\&D costs for the U.S. program on coal gasification have totaled about $\$ 10^{9}$ since 1965 . The total operating time on commercial combined cycle systems in the U.S. is over $6,000,000 \mathrm{hr}$.

\section{RECOMMENDED DEVELOPMENT PROGRAM}

To achieve a thermal efficiency as high as that of coal-fired steam plants, combined-cycle plants must be tightly integrated with coal gasification plants to utilize the relatively large amounts of heat that would otherwise be lost in the coal gasification process. Thic tight integration implies far more complex and difficult operation and control problems than have been encountered heretofore in central power stations. These problems and their implications relative to the manning and staffing requirements for the operation and maintenance of integrated plants will require a development program both for the manpower supply and the redirection of the management of utilities to include the disciplines required for the operation of a chemical plant. 
The operating history of existing coal gasification plants, sulfur removal systems, and combined-cycle plants should be examined to establish the incidence of both forced and scheduled outages of these units and the associated amounts of downtime. The results should then be applied to yield an estlmate of the reliability and availability of the integrated plant. If the estimates prove to be disappointingly low, the possibilities for improving the reliability and availability should be examined because they could influence the direction of the program.

If the capital, fuel, and operating cost of a combined-cycle-coal gasification plant complex is to be appreciably lower than that for a conventional coal-fired steam plant, it will be necessary to increase the gas turbine inlet temperature substantially over the highest values that have proved practicable to date for central station base-load service. The advantages that higher gas turbine inlet temperatures would confer should not be taken for granted because there is reason to doubt that any of the three approaches under active development (air-cooled, watercooled, or ceramic turbine blades) will prove successful.5,6 In particular, to keep costs reasonable, the fuel will probably have a higher sulfur and particulate content than natural gas or distillate fuels. Thus a heavy financial commitment to this type of system should be contingent on a demonstration that a gas turbine inlet temperature in the 1200 to $1370^{\circ} \mathrm{C}$ range is feasible with fuel from a coal gasification plant. Such a test has been proposed using a Curtiss-Wright turbine with air-cooled blades fueled by the slagging gasifier in the Westfield plant in scotland. It appears that such a test could be run expeditiously and should prove eminently worthwhile because it should demonstrate whether the complex and relatively delicate construction required to make it possible to operate air-cooled turbine blades with a $\sim 1370^{\circ} \mathrm{C}\left(2500^{\circ} \mathrm{F}\right)$ gas temperature will be practicable with low-Btu gas from a coal gasification plant.

PRINCIPAL PROBLEMS AND PARAMETERS

The gas turbine-steam combined cycle utilizing present technology and operating experience can demonstrate efficiencies of 40 to $42 \%$ compared to $38 \%$ for the most modern coal-fired steam plant. ${ }^{39}, 40$ In order 
to attain these efficiencies, the gas turbine must operate with an inlet temperature of 1000 to $1100^{\circ} \mathrm{C}$ and a particulate content in the combustion gas of less than $1 \mathrm{ppm}^{4}{ }^{4}, 40,41$ This in turn requires that the turbine be supplied with clean fuels such as natural gas or distillate oil. Increasing the turbine inlet temperature will result in an increase in the combined-cycle efficiency because it increases both the gas turbine efficiency and the temperature of the gas turbine exhaust from which heat is supplied to the steam system (see Fig. 4).

\section{Matching the Steam Cycle to the Gas Turbine Cycle}

When raising steam by cooling a hot gas, one is confronted by a fundamental heat transfer problem. That is, the bulk of the heat is absorbed in the water boiler at the saturation temperature, which must be almost as low as the exit temperature of the gas in order to provide a positive temperature differential throughout the length of the hoiler. The situation is illustrated in Fig. 5 for typical steam conditions. Note the "pinch point" at the left of the diagram, which determines the upper limit of the steam pressure that can be used with a given turbine exhaust temperature if no afterburner is employed. Note also that superheating gives little increase in steam cycle efficiency relative to an increase in saturation temperature (Fig. 6). This is because as the superheating is increased, the temperature-entropy diagram departs progressively more from that for the ideal rectangular Carnot cycle diagram (see Appendix B). The principal value of superheating is that it eases, problems with turbine erosion and moisture churning losses.

One way of getting heat into the steam cycle at a higher temperature is to use a dual pressure cycle with the higher pressure portion absorbing half the heat from the hot gas and the lower pressure portion absorbing the other half. This entails passing the higher temperature steam through an intermediate pressure turbine from which it leaves at the same pressure as that of the steam from the lower pressure boiler so that the two steam streams can feed the low-pressure turbine. The increased cost of the more complex steam system is small relative to the increase in output obtained. Figure 7 indicates the temperature distribution in a dual 


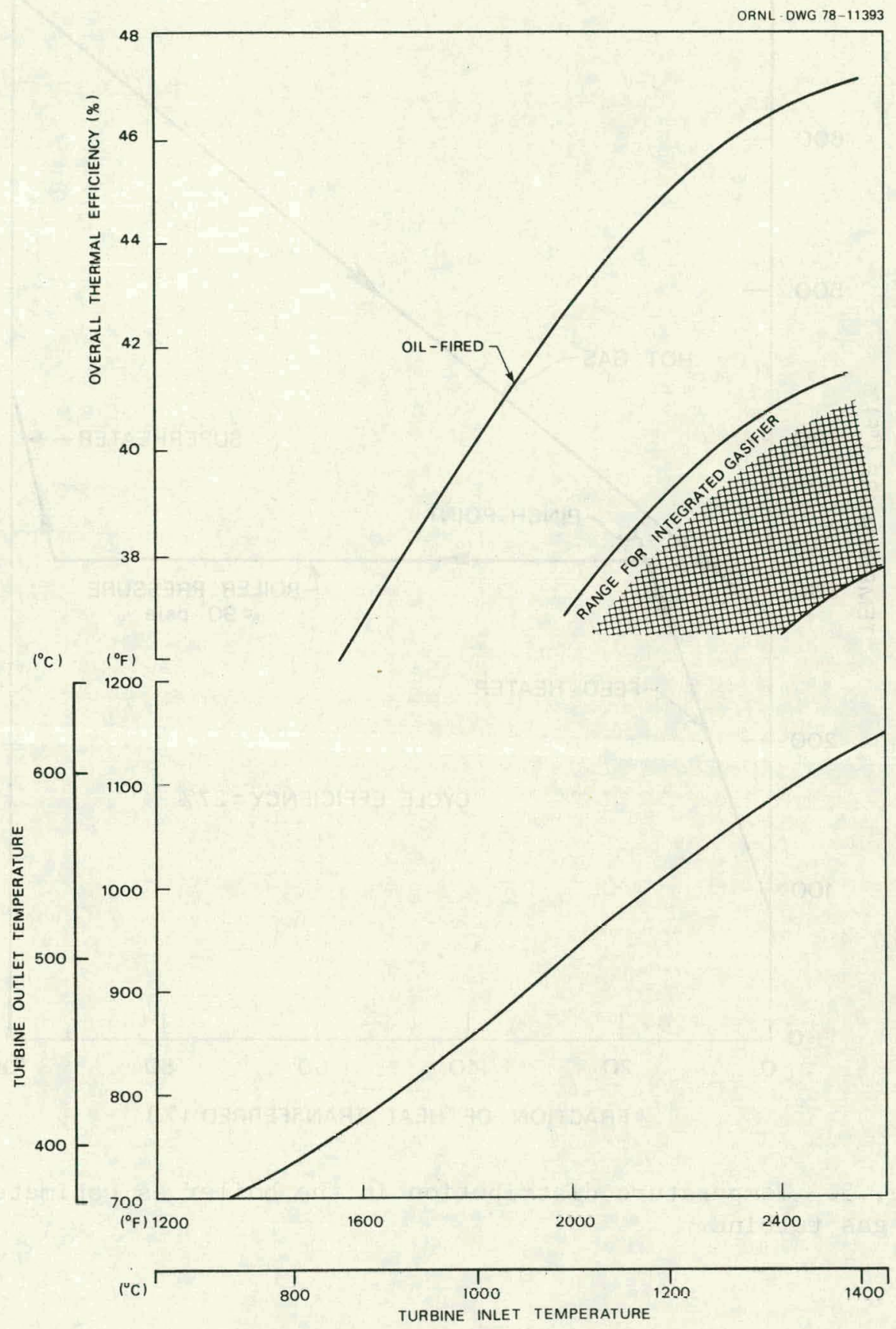

Fig. 4. Effects of gas turbine inlet temperature on the turbine outlet temperature and the overall thermal efficiency of a combined cycle with oil firing and component efficiencies of $90 \%$. 


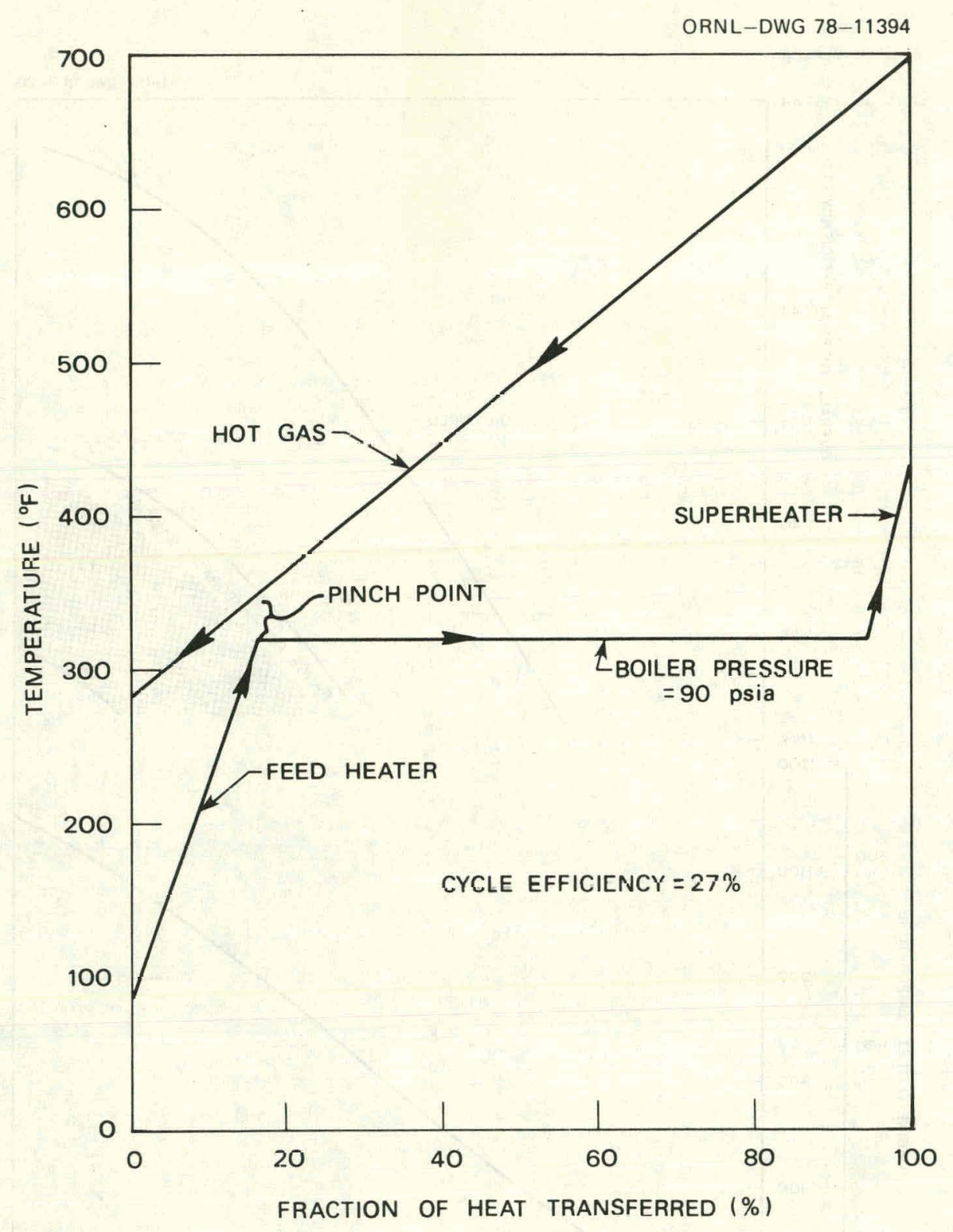

Fig. 5. Temperature distribution in the boiler as estimated for a typical gas turbine.

pressure boiler for the same hot gas conditions as used in Fig. 5. The estimated efficiencies for the steam cycles and for the combined dua1 pressure cycle are indicated in Figs. 5 and 7. If the turbine inlet and outlet temperatures were increased, the pressures and temperatures in the steam cycles could be increased to give an increase in the overall steam cycle efficiency. 


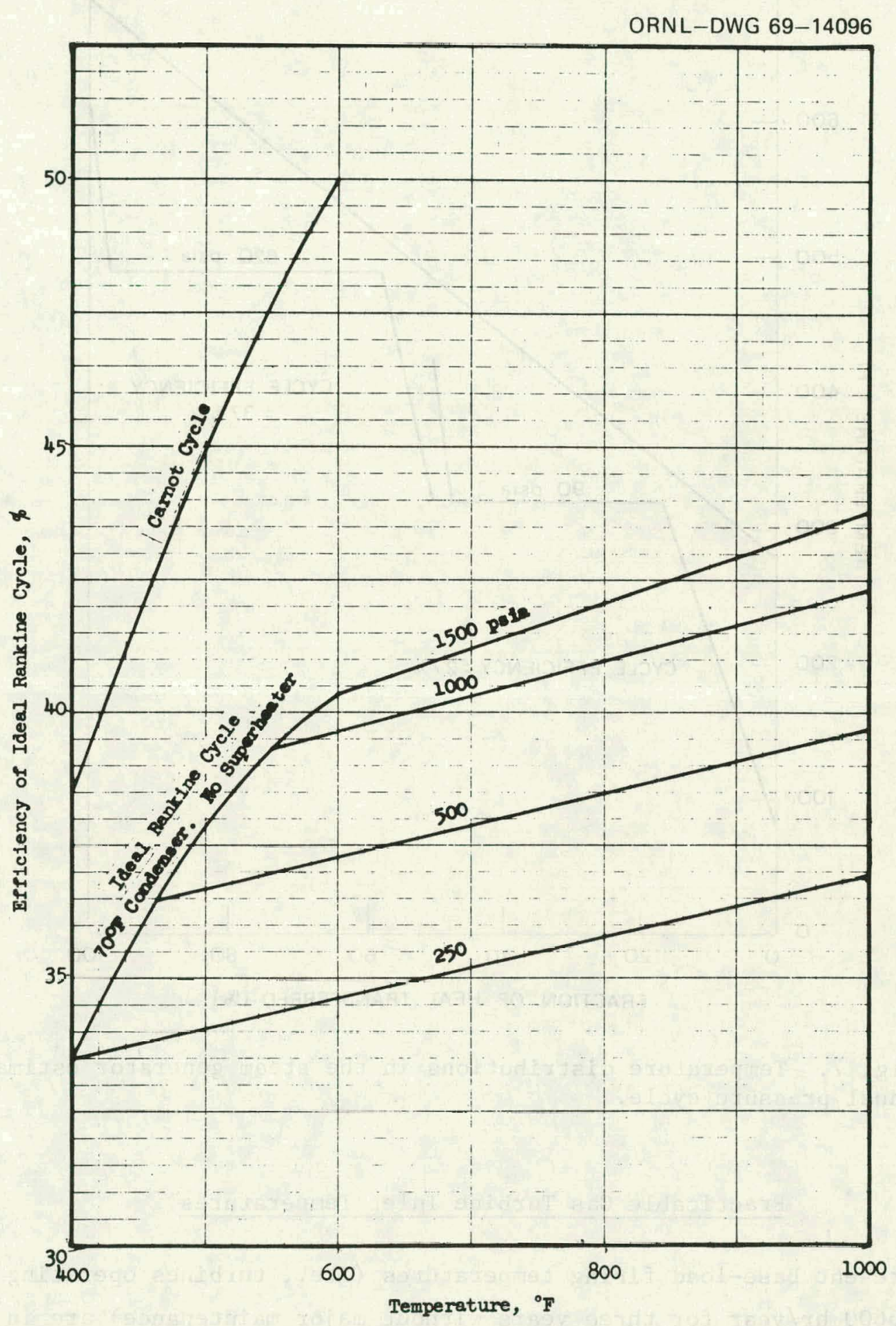

Fig. 6. Effects of temperature on the efficiency of a series of steam cycles showing the effects of superheat. 


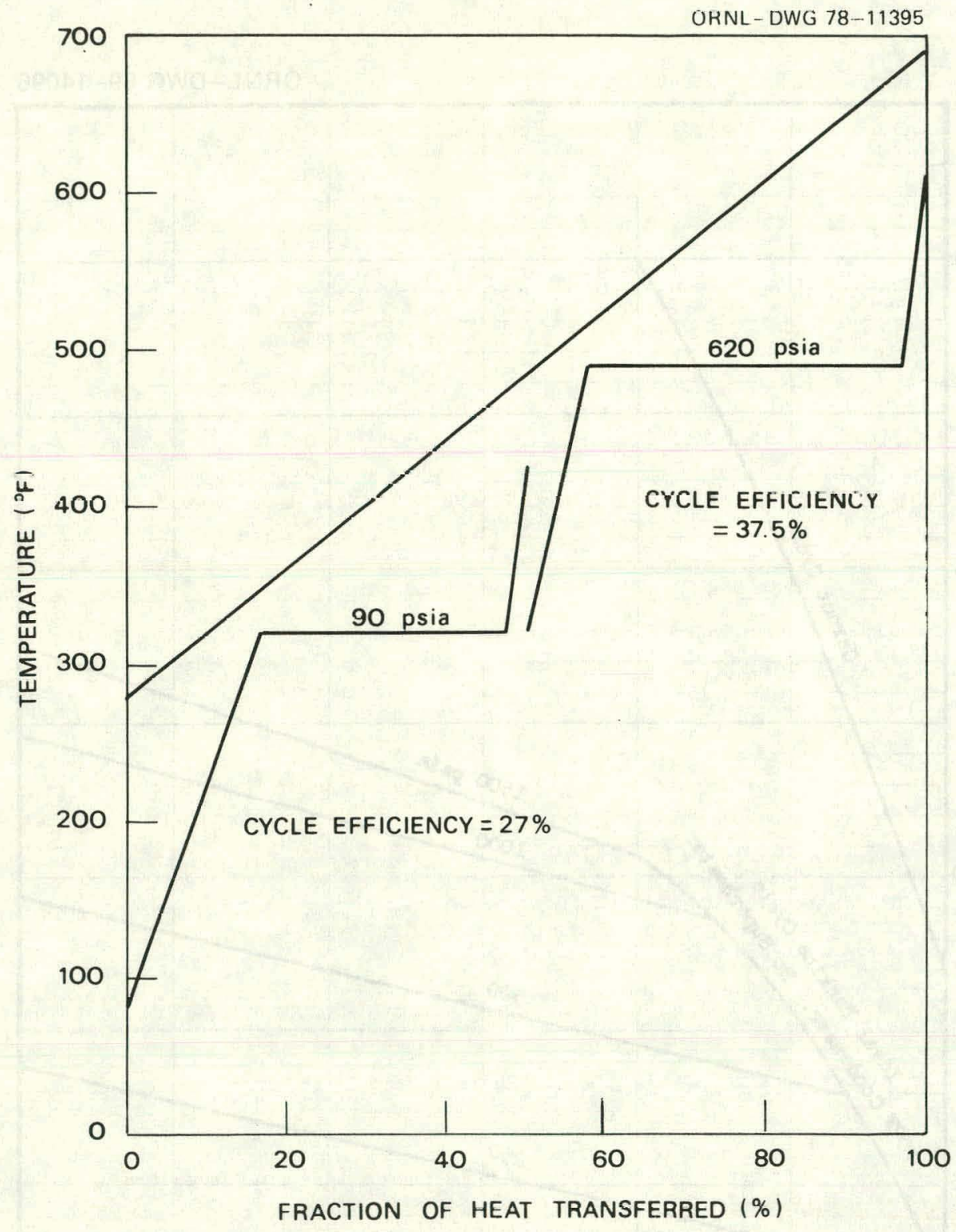

Fig. 7. 'lemperature distributions in the steam generator estimated for a dual pressure cycle.

\section{Practicable Gas Turbine Inlet Temperatures}

Present base-load firing temperatures (i.e., turbines operating at least $6600 \mathrm{hr} /$ year for three years without major maintenance) are in the range of 1000 to $1050^{\circ} \mathrm{C} .^{42}$ Increasing the allowable base-load firing temperatures will require the development of improved methods of turbine blade cooling, possibly water cooling, or improved blade materials such 
as ceramics. The prospects for the success of these approaches are examined in other reports in this series. ${ }^{5,6}$ Ceramic blades do not appear practicable, the point of diminishing returns seems to be near for air cooling, and water cooling seems to yield designs that are not only extremely complex in order to keep thermal stresses to tolerable levels, but also have heat fluxes that are so high that there is little margin in the cooling system to accommodate deviations from ideality that might yield burnout heat fluxes. As a consequence, commercial application is far from certain.

\section{Efficient Utilization of Energy in Coal}

There are two basic approaches to the use of coal-derived fuels in combined cycles. The first integrates the coal gasification plant and the combined-cycle utility plant, so that heat losses from the coal gasification process can be used to advantage in the steam cycle; the second locates the coal gasification plant and the combined-cycle utility plant at different sites. The "cold-gas efficiencies" claimed for various coal conversion systems range from 65 to $90 \%$. $^{32,43-45}$ However, the writers have been unable to find any test data obtained from an actual pilot or demonstration plant that yield efficiencies of conversion of the chemical energy in the coal into chemical energy in the product in excess of $67 \%$ after allowances for energy inputs represented by steam, compressed air, oxygen (if used), and circulating pumps together with losses in the gas cleanup train for removing sulfur and particulates. It a higher value of $75 \%$ is taken as possible, this would represent a $25 \%$ efficiency penalty that would be applied to combined-cycle plants not integrated with the coal conversion plant; this would give the combined cycle plant a higher fucl concumption than a conventinnal. steam plant. Thus, for an attractive overall thermal efficiency, the more promising approach appears to be to integrate the coal gasification plant with the combined-cycle plant.

Effects of coal conversion process efficiency and heat recovery temperature

Close integration of a coal gasification plant with a combined cycle that utilizes the waste heat from the gasifier gives a system whose overall 
thermal efficiency is difficult to appraise. To get some perspective, one can draw an envelope around the coal gasification plant. To a first approximation the chemical energy in the coal flowing into the plant will be equal to the chemical energy in the fuel gas leaving the plant, plus the waste heat recovered in the form of steam at a useful temperature, plus the unrecoverable heat losses to the surroundings or to low-temperature cooling streams. Ideally, the fuel gas from the gasifier would flow to the burner of the combined cycle at a high temperature, so that the sensible heat in this fuel gas would also be part of the energy output; however, in most gasification processes the gas must be cooled to remove sulfur and particulates. Hence, the sensible heat in the fuel gas is usually small, so that the parameter "cold gas conversion efficiency" is commonly used. An examination of data for typical plants indicates that the heat losses to the surroundings plus allowances for pumping power (including the thermal efficiency of the system for generating that power) commonly run roughly $7 \%$. The sensible heat recovered from the coal gasification process can be utilized either for feedwater heating or for a low-pressure steam cycle; the overall plant thermal efficiency will be the same in either case. For purposes of this analysis, it is simpler to treat this intermediate-temperature heat as if it were utilized in a simple steam cycle which (with allowances for conventional component efficiencies) would give cycle efficiencies of $12,25.5,32$, and $33.5 \%$ for steam temperatures of $93,204,316$, and $427^{\circ} \mathrm{C}\left(200,400,600\right.$, and $\left.800^{\circ} \mathrm{F}\right)$, respectively. Thus, there are three major independent variables affecting the overall power plant thermal efficiency: the coal to fuel gas conversion efficiency, the temperature of waste heat recovery from the coal gasification plant, and the gas turbine cycle inlet temperature. This gives too many variables for a simple chart. One way of treating the problem is to calculate first what can be called an "effective cold gas thermal efficiency," which is the cold gas conversion efficiency plus the product of the fraction of the chemical energy in the coal that is recovered as steam at an intermediate temperature and the ratio of the thermal efficiency of the steam cycle for that temperature to the thermal efficiency of the combined cycle at the specified gas turbine inlet temperature (see Fig. 4). The resulting values are shown in the lower part of Fig. 8 for 


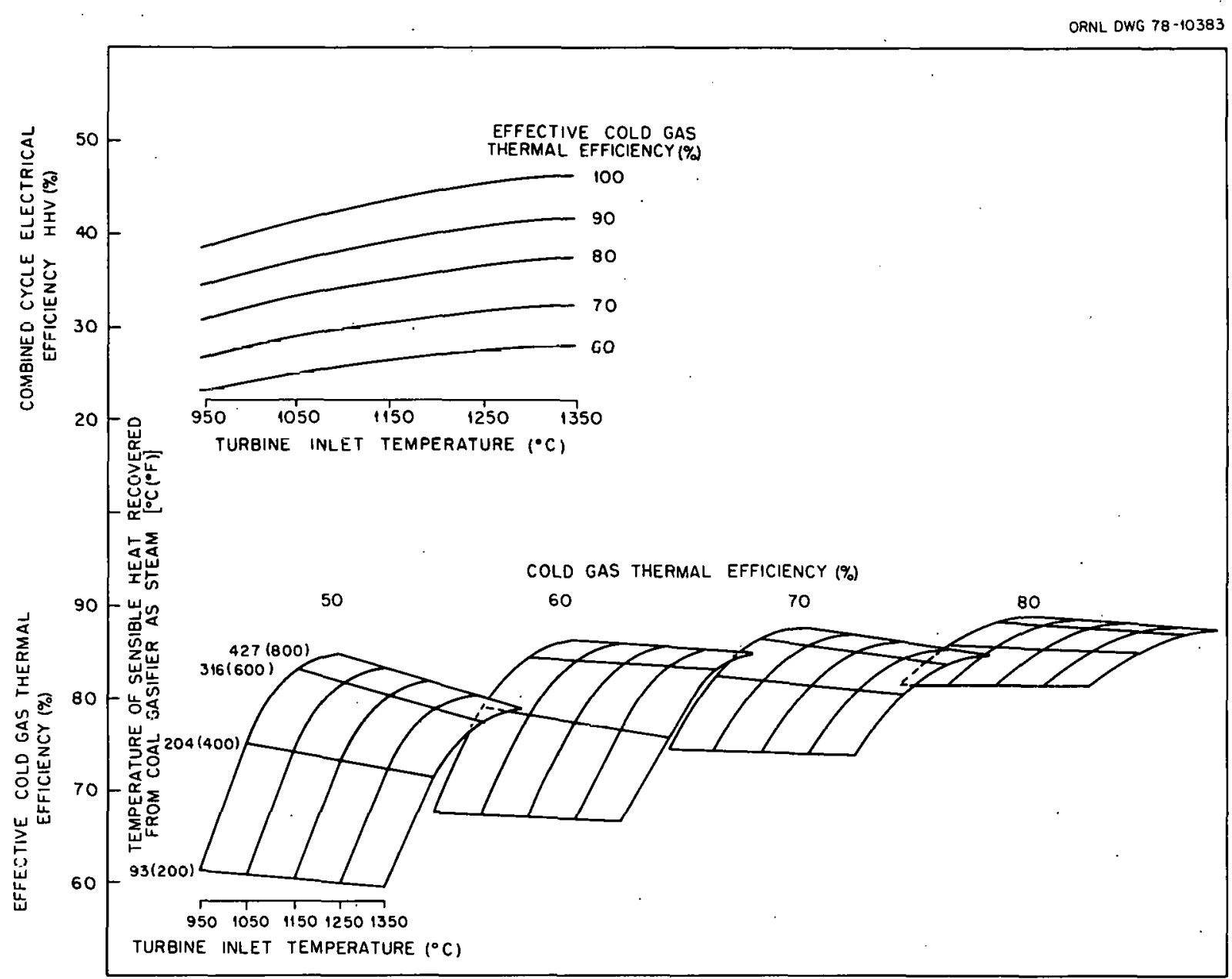

Fig. 8, Effects of cold gas efficiency, sensible heat rejection temperature, and turbine firing temperature on integrated coal gasification combined-cycle power plants.

a series of cold gas thermal efficiencies. Note the marked increase in the "effective cold gas thermal efficiency" with an increase in the temperature at which heat is recovered from the gasifier. The overall thermal efficiency of the plant complex can be found from the chart at the top of Fig. 8 by ucing the effective $\operatorname{cold}$ gas thermal efficiency and the gas turbine inlet temperature. Figure 8 shows that, for a gas turbine inlet temperature of $1100^{\circ} \mathrm{C}\left(2010^{\circ} \mathrm{F}\right)$, an optimistically high cold gas conversion efficiency of $80 \%$, and recovery of waste heat from the gasifier at $204^{\circ} \mathrm{C}$ $\left(4 \cap n^{\circ} \mathrm{F}\right)$, the overall thermal efficiency of the plant complex is on $1 \mathrm{y} \sim 36 \%$, about the same as for a conventional coal-fired steam plant with stack gás 
scrubbers. 'Thus either a higher waste heat recovery temperature or a gas turbine inlet temperature of over $1100^{\circ} \mathrm{C}\left(2010^{\circ} \mathrm{F}\right)$ is needed to make the system attractive.

\section{Characteristics of typical coal gasification processes}

The general subject of coal gasifiers suitable for coupling to a combined cycle is beyond the scope of this report, but an outline of the characteristics and problems of typical gasifiers is needed to provide some insight into the limitations that the various types of gasifier impose on a combined-cycle plant. As pointed out in an excellent article on this set of problems, ${ }^{44}$ the various gasifier types under development can be classified as moving-bed, fluidized-bed, or entrained-flow units' (see Table 1).

In the moving-bed gasifiers, raw coal is fed into the top while stedm and air (or oxygen) enter near the bottom and pass up through the bed in counterflow with the coal. Low-Btu fuel gas leaves at the top at $2500^{\circ} \mathrm{C}$ $\left(932^{\circ} \mathrm{F}\right.$ ) and ash is discharged from the bottom. The bed is stirred mechanically by a slowly rotating paddle, and this requires that a noncaking coal be used with a minimum of fines. Temperatures vary widely from the bottom to the top of the bed, ranging from $\sim 1200^{\circ} \mathrm{C}\left(2200^{\circ} \mathrm{F}\right)$ in the lower part to $\sim 500^{\circ} \mathrm{C}\left(932^{\circ} \mathrm{F}\right)$ at the top. Many units of this type ot gasifier (i.e., the Lurgi) have been used commercially and give a cold gas conversion efficiency of $260 \%$. The process inherently yields a gas with a high tar content which may be removed with a water scrubber. However, thorough cleaning is difficult, and the tars foul heat exchangers and other equipment (a major problem in the Lünen plant of Fig. 3). A variation of this type is the slagging bottom gasifier developed by the British Gas Company. Oxygen rather than air is used to give a temperature of $\sim 1500^{\circ} \mathrm{C}\left(2730^{\circ} \mathrm{F}\right)$ at the bottom of the gasifier so that the ash is above the fusion point and is removed as molten slag. This greatly reduces carbon losses in the ash and makes it possible to handle fines in the coal.

The fluidized-bed gasifiers operate with a fluidized bed of ash or sand held at a constant temperature of 870 to $1040^{\circ} \mathrm{C}\left(1600\right.$ to $\left.1900^{\circ} \mathrm{F}\right)$. Coal or char is fed into the bed, which is fluidized with steam and air or oxygen. The high temperature in the gas leaving the bed is expected to 
Table 1. General comparison of coal gasification reactor types 44

\begin{tabular}{|c|c|c|c|c|}
\hline \multirow{2}{*}{ Function } & \multicolumn{2}{|c|}{ Moving bed } & \multirow{2}{*}{$\begin{array}{c}\text { Fluidized } \\
\text { bed }\end{array}$} & \multirow{2}{*}{$\begin{array}{l}\text { Entrained } \\
\text { flow }\end{array}$} \\
\hline & Dry ash & $\begin{array}{l}\text { Slagging } \\
\text { bottom }\end{array}$ & & \\
\hline Sapacity & Low & High & Intermediate & High \\
\hline Ability to hardle caking coals without pretreatment & Moderate & Moderate & Poor & Excellent \\
\hline Temperature of operation, ${ }^{\circ} \mathrm{F}$ & $2000-800$ & $2800-800$ & $1600-1900$ & $3000-1700$ \\
\hline Temperature control & Poor & Poor & Good & Moderate \\
\hline Refractory problems & Moderate & Poor & Moderate & Poor \\
\hline By-product tar formation & Yes & Yes & Possibly & Probably not \\
\hline Ajility to extract ash low in carbon & Moderate & Good & Moderate & Good \\
\hline Ajility to consume fine carbon particles & Poor & Good & Probably poor & Good \\
\hline
\end{tabular}


make it possible to avoid trouble with tars in the fuel gas. Unfortunately, there is not enough operating experience with this type of gasifier to define the performance characteristics that can be attained.

The entrained-flow gasifier systems supply pulverized coal, steam, and air or oxygen to the bottom of the gasifier. These swirl through the gasifier at sufficiently high velocities that the coal and ash particles are entrained in the gas throughout its transit through the reactor vesse1. About $30 \%$ of the coal, together with the steam and preheated air or oxygen, is injected tangentially into a combustion chamber region at the bottom of the gasifier where the coal is burned essentially stoichiometrically to give a temperature of $21870^{\circ} \mathrm{C}\left(3400^{\circ} \mathrm{F}\right)$. The hot gases pass upward into the gasifying zone, where the balance of the coal feed is injected and much of the sensible heat in the hot gas absorbed in endothermic reactions to yield the fuel gas. The high velocities reduce the transit time so that the carbon is not all consumed in the first pass and hence the entrained ash in the exit gas is removed and recirculated. Ash collected as molten slag on the walls of the combustion chamber is drained off, quenched, and removed as a water slurry.

One must look closely at the energy input and output of a gasifier to get a proper value for its conversion efficiency. Take, for example, the Texaco entrained bed gasifier of Ref. 45. A typical set of data is that from run W1 on page 26 for a test using as feed a tarry residue from a coal liquefaction plant. The cold gas conversion efficiency was a high 83.5\%. However, allowance should be made for the power required to make the oxygen supplied to the gasifier (i.e., $420 \mathrm{~kW} /$ ton of $\mathrm{O}_{2}$ ) or $717 \mathrm{Btu} / 1 \mathrm{~b}$ $\mathrm{O}_{2}$, and when the thermal efficiency of the thermodynamic cycle for generating this power is taken into account, one finds that the corrected conversion efficiency is reduced to $272 \%$. A further allowance for the energy in the steam fed to the gasifier reduces the corrected cold gas conversion efficiency to $70 \%$. A sulfur removal system would degrade it further by about two points, and pumping losses would amount to another point or two. Thus, the cold gas efficiency after correction for all these factors would be $266 \%$ - not $83.5 \%$. Further, the energy losses representing the difference between $83.5 \%$ and $66 \%$ would yield heat at too low a temperature to be of much value in the steam cycle. 
$\underline{\text { Plant integration problems }}$

An excellent treatment of the economics of integrating coal gasifiers with combined cycle plants is presented in a recent EPRI report ${ }^{32}$ which gives many details on the equipment required for the coal gasification and fuel gas cleanup systems. There is enough detailed data in tables and flowsheets to provide good quantitative estimates of the principal losses for each of the seven systems studied. Table 2 summarizes key data for these seven systems for which the design conditions were chosen so that the results should be comparable. For example, the gas turbine inlet temperature and pressure ratio, the steam cycle conditions, and the stack gas temperatures were the same in all cases. The design power output varied somewhat, but only $\pm 10 \%$. It is interesting to note that, when the principal losses are taken into account, the highest overall thermal efficiency for any of the systems was $40.6 \%$ (based on the fuel higher heating value, HHV), which is much less than the $46.8 \%$ of the Westinghouse ECAS study. ${ }^{34}$

To bring about the wide use of coal-derived fuels in combined gas turbine-steam plants, two developments are necessary. The first is the development of an efficient coal gasification process that will handle a wide range of coals with varying analyses and characteristics; the second is the development of a gas turbine that can utilize the coalderived fuels with a turbine inlet temperature above $1100^{\circ} \mathrm{C}$.

In attempting to appraise the prospects for improving the conversion efficiency of coal gasifiers, it should be remembered that coal gasification has been used commercially for 175 years and that around $\$ 10^{9}$ has been spent on coal conversion in the U.S. in the past 12 years. Still no pilot plant has yet given a corrected conversion efficiency (including allowances for sulfur removal) of more than $\sim 67 \%$ and none has operated for over a year without serious trouble.

The principal problems in the development of the gas turbine-steam cycle itself are largely those associated with increasing the permissible inlet temperature for the gas turbine. The combined gas turbine-steam cycle fuel rate improves approximately $2 \%$ for a rise of $55^{\circ} \mathrm{C}$ in the gas turbine inlet temperature and $7.8 \%$ for an increase of $1 \%$ in the average component efficiency (see Appendix B). 
Table 2. Summz:y of key performance cata for zoal gasifier gas turbine combined sycle power plant

\begin{tabular}{|c|c|c|c|c|c|c|c|}
\hline & $\begin{array}{l}\text { Lurgi } \\
\text { MACW }\end{array}$ & $\begin{array}{c}\text { BGC slagzer } \\
\text { MXSC }\end{array}$ & $\begin{array}{l}\text { Foster } \\
\text { Wheeler } \\
\text { EAHC }\end{array}$ & $\begin{array}{l}\text { Foster } \\
\text { Wheeler } \\
\text { EXHC }\end{array}$ & $\begin{array}{l}\text { Combustion } \\
\text { Engineering } \\
\text { EALC }\end{array}$ & $\begin{array}{c}\text { Texaco } \\
\text { EXTC } \\
\text { (slurry feed) }\end{array}$ & $\begin{array}{c}\text { Texaco } \\
\text { EXTC } \\
\text { (dry feed) }\end{array}$ \\
\hline \multicolumn{8}{|l|}{ Gasification and gas cleaning system } \\
\hline 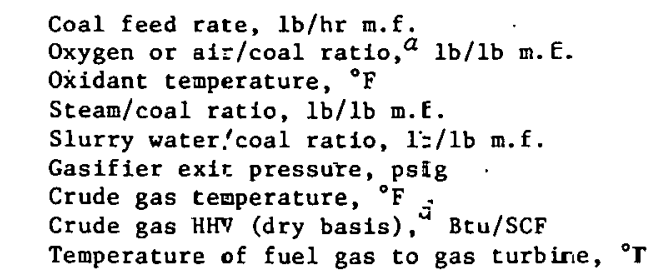 & $\begin{array}{l}1,014,814 \\
1.562 \\
340 \\
0.758 \\
\text { NA } \\
340 \\
861 \\
189.1 \\
425\end{array}$ & $\begin{array}{l}798,333 \\
3.481 \\
214 \\
3.31 \\
2 \mathrm{~A} \\
320 \\
320 \\
379.0 \\
580\end{array}$ & $\begin{array}{l}798,333 \\
2.857 \\
800 \\
0.150 \\
\text { NA } \\
360 \\
1,700 \\
174.1 \\
800\end{array}$ & $\begin{array}{l}798,333 \\
0.609 \\
335 \\
0.624 \\
\text { NA } \\
360 \\
1,700 \\
315.4 \\
800\end{array}$ & $\begin{array}{l}398,333 \\
<.37 \\
<37 \\
C \\
\text { PA } \\
\text { I, } 700 \\
113.0 \\
i, 200\end{array}$ & $\begin{array}{l}798,333 \\
0.858 \\
300 \\
0 \\
0.503 \\
600^{c} \\
2,300-2,600 \\
281.1 \\
781\end{array}$ & $\begin{array}{l}798,333 \\
0.806 \\
300 \\
0.610 \\
\text { NA } \\
600^{c} \\
2,300-2,600 \\
280.7 \\
781\end{array}$ \\
\hline \multicolumn{8}{|l|}{ Power system } \\
\hline $\begin{array}{l}\text { Gas turbine inlet temperat }-r e,{ }^{\circ} \mathrm{F} \\
\text { Pressure ratio } \\
\text { Gas turbine exhaust temperature, }{ }^{\circ} \mathrm{F} \\
\text { Steam conditions, psig/ } /{ }^{\circ} \mathrm{F} /{ }^{3} \mathrm{~F} \\
\text { Condensing pressure, in. H马 abs. } \\
\text { Stack temperature, }{ }^{\circ} \mathrm{F} \\
\text { Gas turbine power, } \mathrm{MW} \\
\text { Steam turbine power, }{ }^{\mathrm{e}} \mathrm{MW} \\
\text { Power consumed, MW } \\
\text { Net system power, MW }\end{array}$ & $\begin{array}{l}2,400 \\
17: 1 \\
1,137 \\
1450 / 900 / 1000 \\
2.5 \\
275 \\
590 \\
430 \\
32 \\
988\end{array}$ & $\begin{array}{l}2,400 \\
07: 1 \\
0,128 \\
1450 / 900 / 1000 \\
2.5 \\
275 \\
357 \\
385 \\
30 \\
1,212\end{array}$ & $\begin{array}{l}2,400 \\
17: 1 \\
1,127 \\
1450 / 900 / 1000 \\
2.5 \\
275 \\
751 \\
504 \\
42 \\
1,213\end{array}$ & $\begin{array}{l}2,400 \\
17: 1 \\
1,133 \\
1450 / 900 / 1000 \\
2.5 \\
275 \\
803 \\
384 \\
38 \\
1,149\end{array}$ & $\begin{array}{l}2,400 \\
i 7: 1 \\
i \times 147 \\
1450 / 900 / 1000 \\
2.5 \\
275 \\
8 \varepsilon 6 \\
3 C 7 \\
55 \\
=, 138\end{array}$ & $\begin{array}{l}2,400 \\
17: 1 \\
1,140 \\
1450 / 900 / 1000 \\
2.5 \\
272 \\
745 \\
448 \\
36 \\
1,157\end{array}$ & $\begin{array}{l}2,400 \\
17: 1 \\
1,140 \\
1450 / 900 / 1000 \\
2.5 \\
272 \\
763 \\
425 \\
46 \\
1,142\end{array}$ \\
\hline \multicolumn{8}{|l|}{ Overall System } \\
\hline $\begin{array}{l}\text { Process and deaerater make-p water, } \\
\mathrm{gpm} / 1000 \mathrm{MW}\end{array}$ & 2,207 & 334 & 497 & 1,031 & $: 57$ & 362 & 1,072 \\
\hline 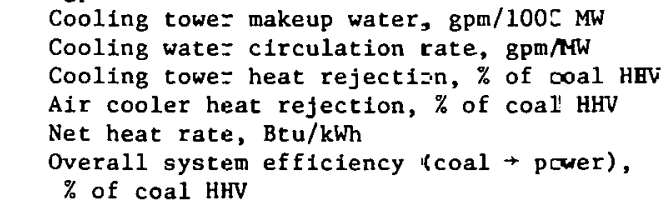 & $\begin{array}{l}5,698 \\
366 \\
33.9 \\
6.5 \\
9,762 \\
34.96\end{array}$ & $\begin{array}{l}5,882 \\
307 \\
33.8 \\
4.7 \\
3,410 \\
40.6\end{array}$ & $\begin{array}{l}6,125 \\
341 \\
36.8 \\
3.2 \\
8,428 \\
40.5\end{array}$ & $\begin{array}{l}6,003 \\
321 \\
33.2 \\
7.2 \\
8,876 \\
38.5\end{array}$ & $\begin{array}{l}3,439 \\
343 \\
37.6 \\
0.9 \\
8,959 \\
3 E .1\end{array}$ & $\begin{array}{l}7,588 \\
347 \\
38.7 \\
5.2 \\
8,813 \\
38.7\end{array}$ & $\begin{array}{l}7,255 \\
352 \\
35.6 \\
4.6 \\
8,928 \\
38.2\end{array}$ \\
\hline
\end{tabular}

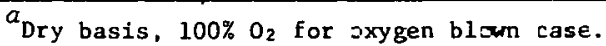

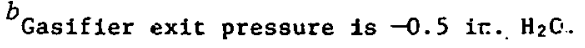

$c_{\text {Average gasifier pressure. }}$

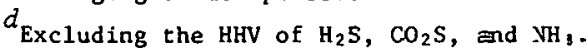

$e_{\text {At genera:or terminals. }}$. 


\section{$\underline{\text { Efficiency }}$}

The possibilities of improving the thermal efficiency of the gas turbine cycle itself deserve some discussion to indicate the possibility of taking this course to improve the efficiency of the combined cycle. Considering the actual installations of gas turbines by electric utilities, a few were made in the late 1940 's, approximately 50 installations were made during the $1950^{\prime} \mathrm{s}$, and wide acceptance of the units began in the 1960 's with 24 units being installed in the 1960 to 1962 period. This trend continued into the 1970's with an estimated $20 \%$ of the new installed capacity of utilities in 1971 being gas turbine driven. ${ }^{23}$ The majority of the units installed in the 1950 to 1976 period were simple open-cycle systems installed as generator drives for peaking and standby service. To obtain a higher gas turbine cycle efficiency, a small number of regenerative cycle units were installed by utilities. Figure 9 shows the effects of turbine inlet temperature upon the thermal efficiency for some typical utility installations of both simple open-cycle gas turbines and open cycles with regeneration built during the 1950 to 1976 period. ${ }^{19-28}$ Inspection of Fig. 9 indicates that, after design, capital, and cost compromises were made, little was gained in efficiency by regeneration at turbine inlet temperatures below approximately $900^{\circ} \mathrm{C}$.

Figure 10 shows the relationship between the thermal efficiency, the compressor pressure ratio, and the turbine inlet temperature for a series of typical modern gas turbines. The data for this graph were adapted from data given in Ref. 46 and are representative of the present state of the art. The calculations were based upon compressor, turbine, and combustion efficiencies of 89,88 , and $100 \%$, respectively. It was also assumed that at an inlet temperature of $870^{\circ} \mathrm{C}, 2 \%$ of the air is bled from the compressor for cooling the seal structure; none is required for turbine blade cooling. At $1370^{\circ} \mathrm{C}\left(2500^{\circ} \mathrm{F}\right), 2 \%$ of the compressor air flow is for cooling the seal structure and $10 \%$ for cooling the turbine. It was further assumed that the $10 \%$ airflow for turbine cooling varied linearly between the turbine inlet temperatures of 870 and $1370^{\circ} \mathrm{C}$. It can be seen from inspection of Fig. 10 that increasing the turbine inlet temperature up 


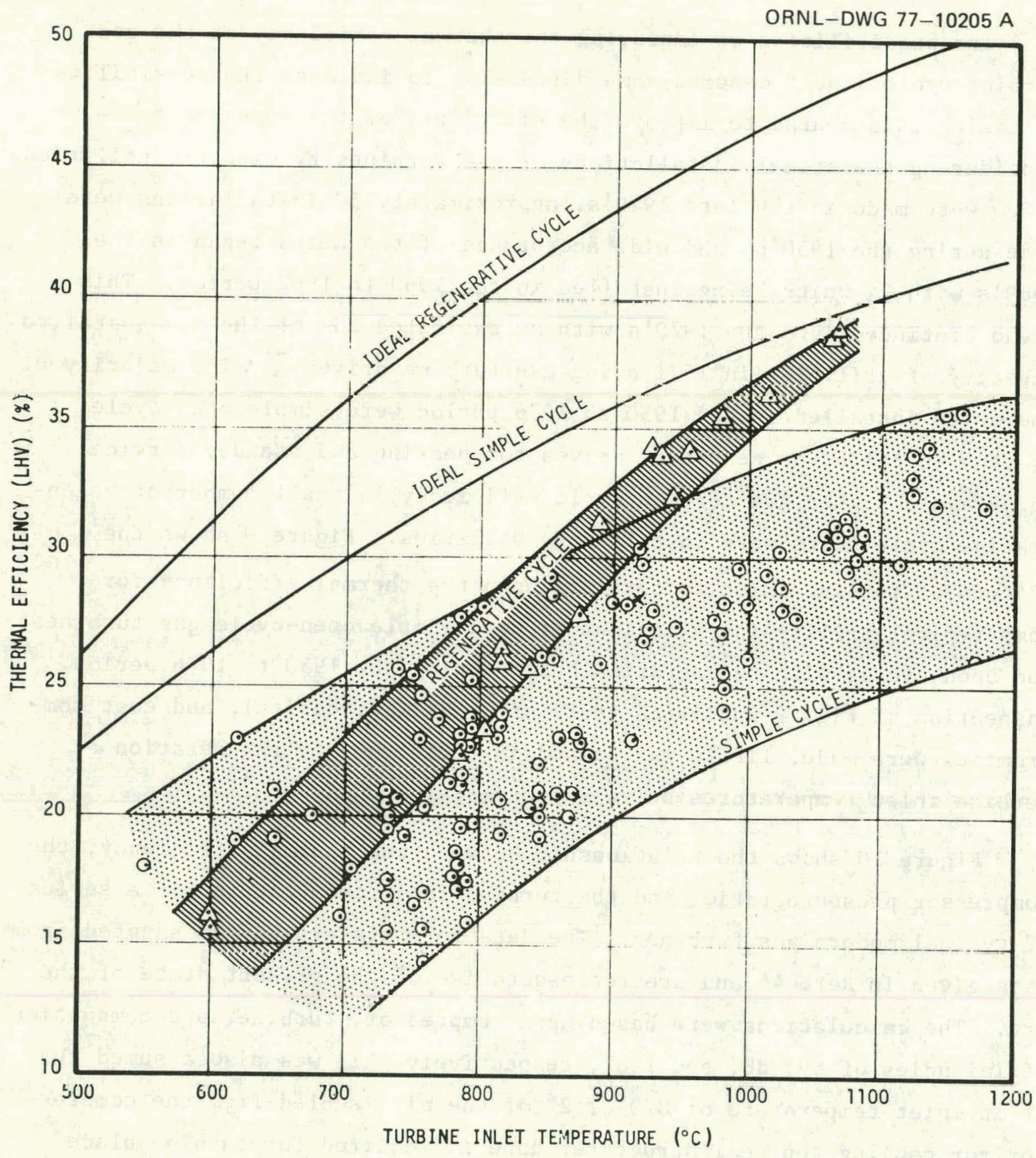

Fig. 9. Reported turbine inlet temperature and thermal efficiency for units installed during the $1950-1976$ period compared to the ideal efficiency of a simple open and a regenerative cycle with a compressor efficiency of $88 \%$ and a turbine efficiency of $90 \%$. 


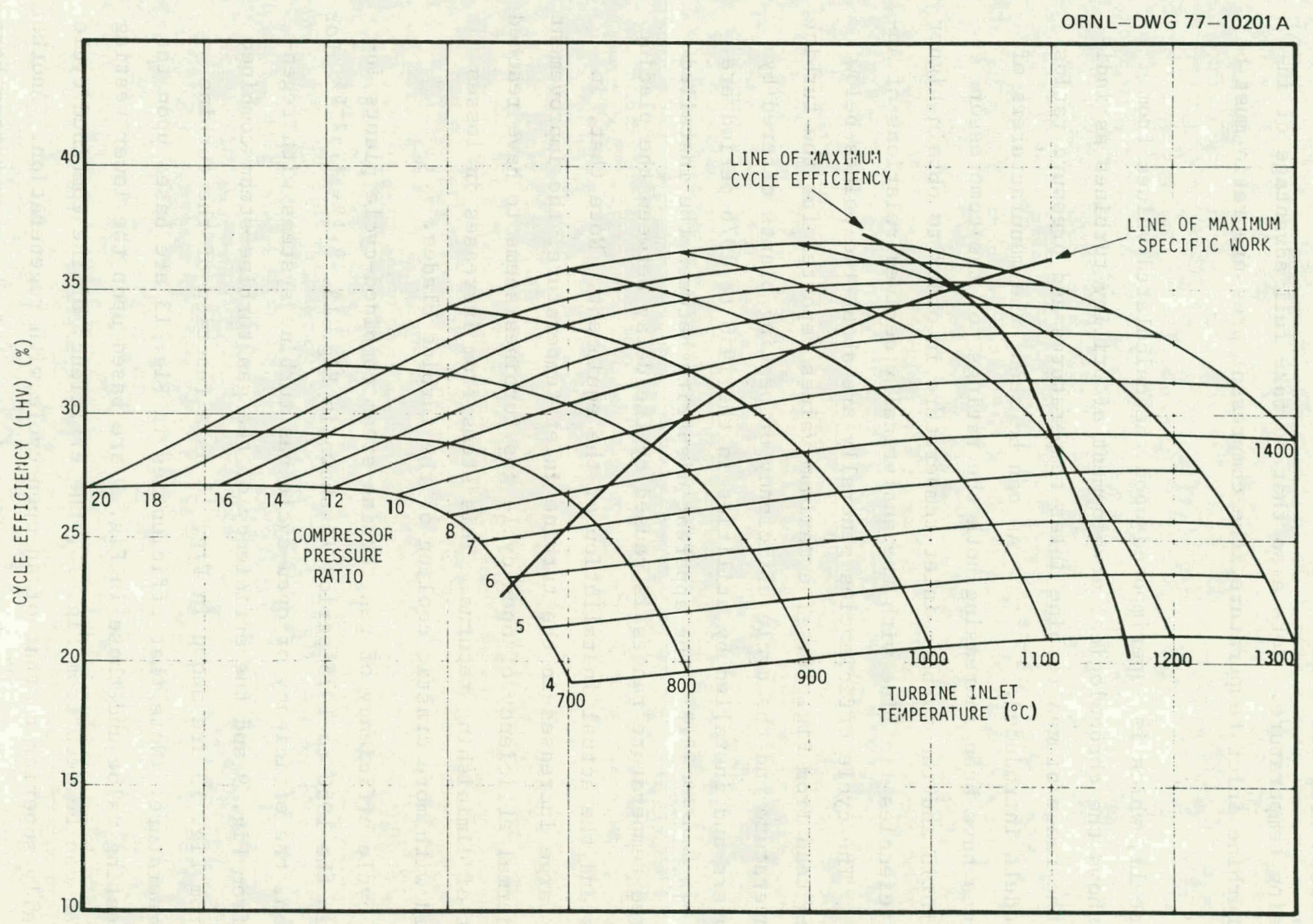

Fig. 10. Effects of compressor pressure ratio and turbine inlet temperature on the thermal efficiency of open-cycle gas turbines. 
to $\sim 1370^{\circ} \mathrm{C}$ increases the thermal efficiency, but above $1370^{\circ} \mathrm{C}$ the increasing losses from air cooling begin to more than offset the effects of increasing temperature. Note also that to take full advantage of increasing turbine inlet temperature, the compressor pressure ratio must be increased.

Figure 11, which is superimposed upon the calculated values from Fig. 10, shows the chronological development of utility turbines as indicated by the range of gas turbine inlet temperatures and pressure ratios for new models introduced. ${ }^{19-28,47}$ As can be seen, the manufacturers of gas turbines have been increasing both the ratings for the compressor pressure ratio and the turbine inlet temperature in order to obtain higher cycle efficiencies (in line with the analytically derived relations of Appendix B). The cycle efficiencies generally are about two points below the values read from Fig. 10. The maximum values reported for the turbine inlet temperature and the cycle efficiency of peaking plants offered by manufacturers and installed by utilities in the 1950 to 1976 period are shown in Fig. 12.19-28,47 The apparent disparity between the installed and offered temperature ranges is caused by the delay between the placing of orders and the actual installation of the equipment. Note that, in spite of large increases in the turbine inlet temperature, the improvement in the thermal efficiency of open-cycle gas turbines seems to have reached the point of diminishing returns. This stems from increases in losses associated with more drastic cooling of the turbine blades. 5

The cycle efficiency of gas turbine-steam combined-cycle plants installed in the 1950 to 1975 period is shown in Fig. 13. 18,19,33,47-55 For comparison, the efficiency of open-cycle gas turbine systems with regeneration from Fig. 9 and the efficiency of the gas turbine-steam combined system from Fig. 13 are shown in Fig. 14 as a function of the turbine inlet temperature. Note that efficiencies in Fig. 13 are based upon the higher heating value and those in Fig. 9 are based upon the lower heating value. As can be seen from Fig. 14, the efficiency of the combined cycle is generally superior to that of an open cycle with regeneration. Another important factor favoring the combined cycle is that the much better heat transfer coefficient on the water side of the heat exchangers used for the 
ORNL-DWG 77-10204 A

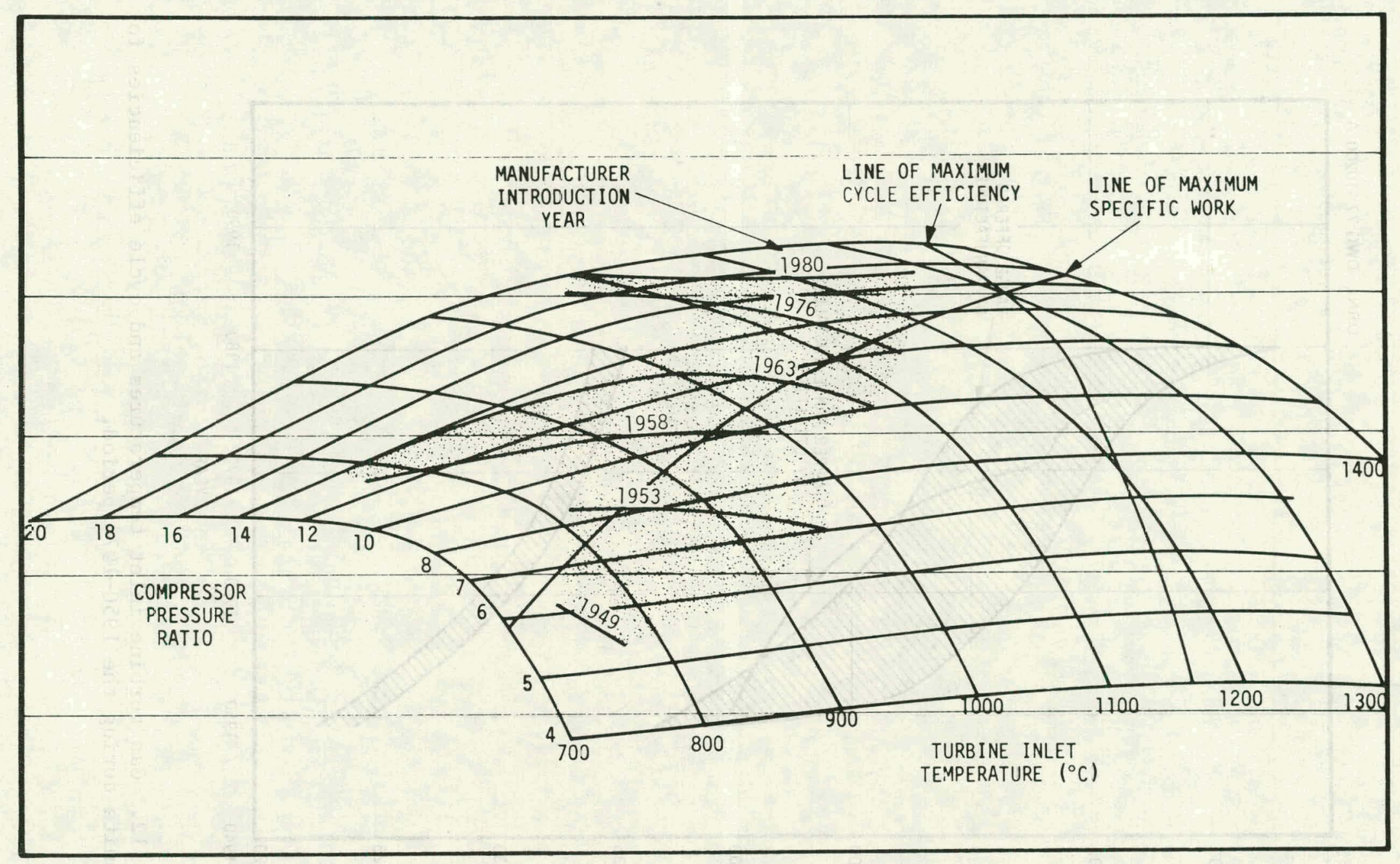

Fig. 11. Reported performance of open-cycle gas turbines introduced during the 1949-1980 period. 


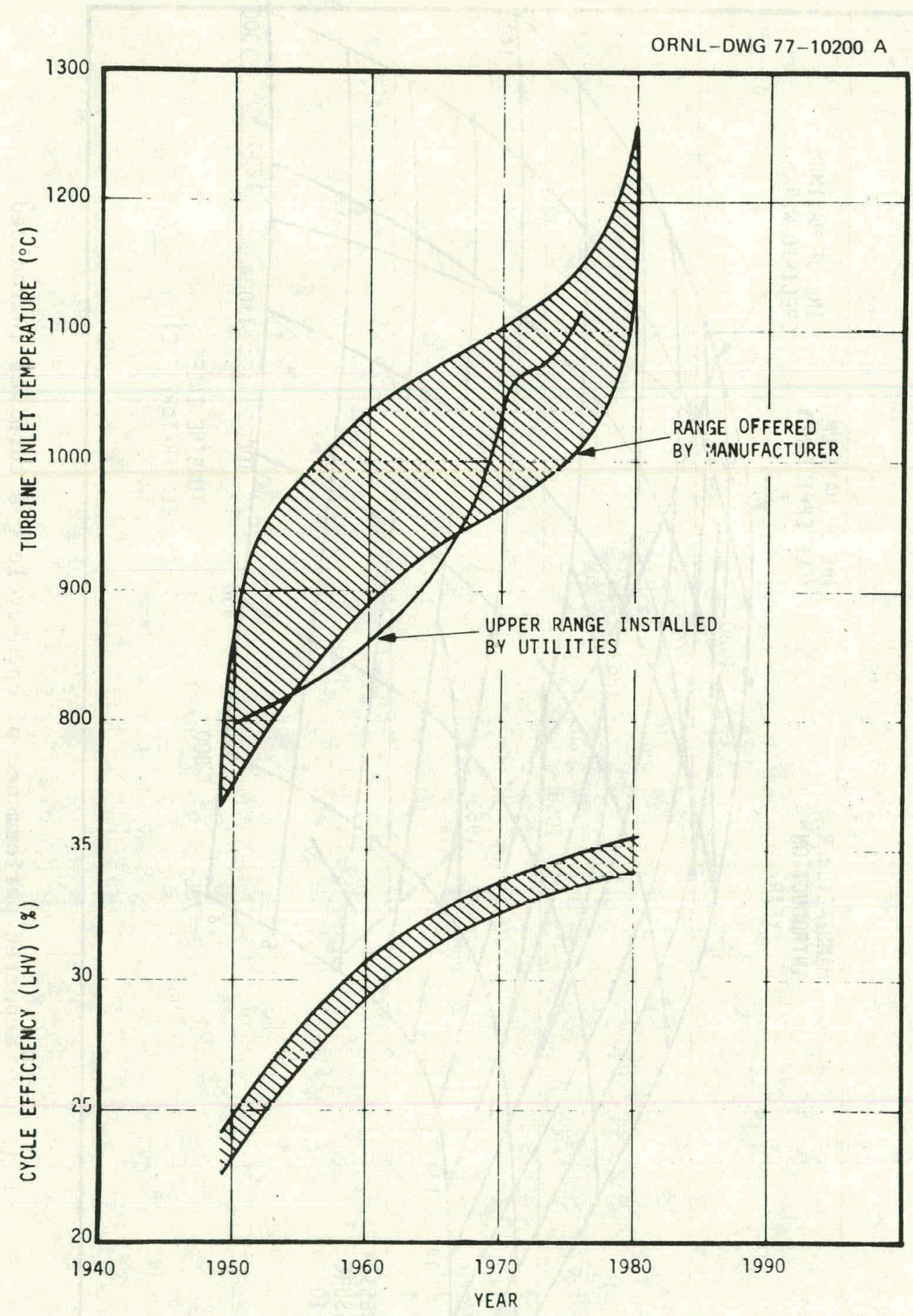

Fig. 12. Gas turbine inlet temperatures and cycle efficiencies for peaking units during the 1950-1976 period. 


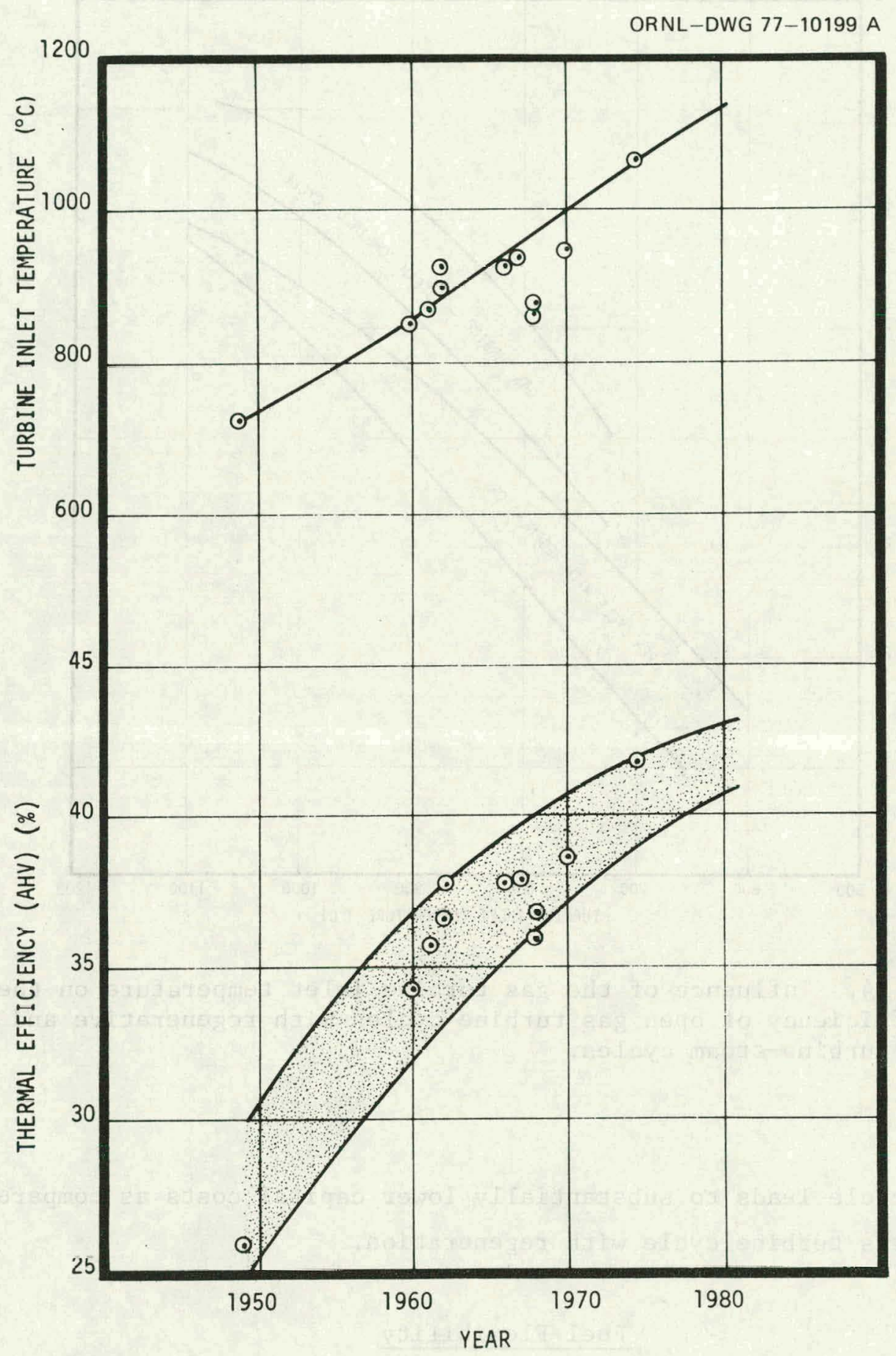

Fig. 13. Plant thermal efficiency (HHV) and turbine inlet temperature for gas turbine-steam combined systems installed during the 1950-1975 period. Iso conditions, No. 2 fuel oil, base-load rating. 


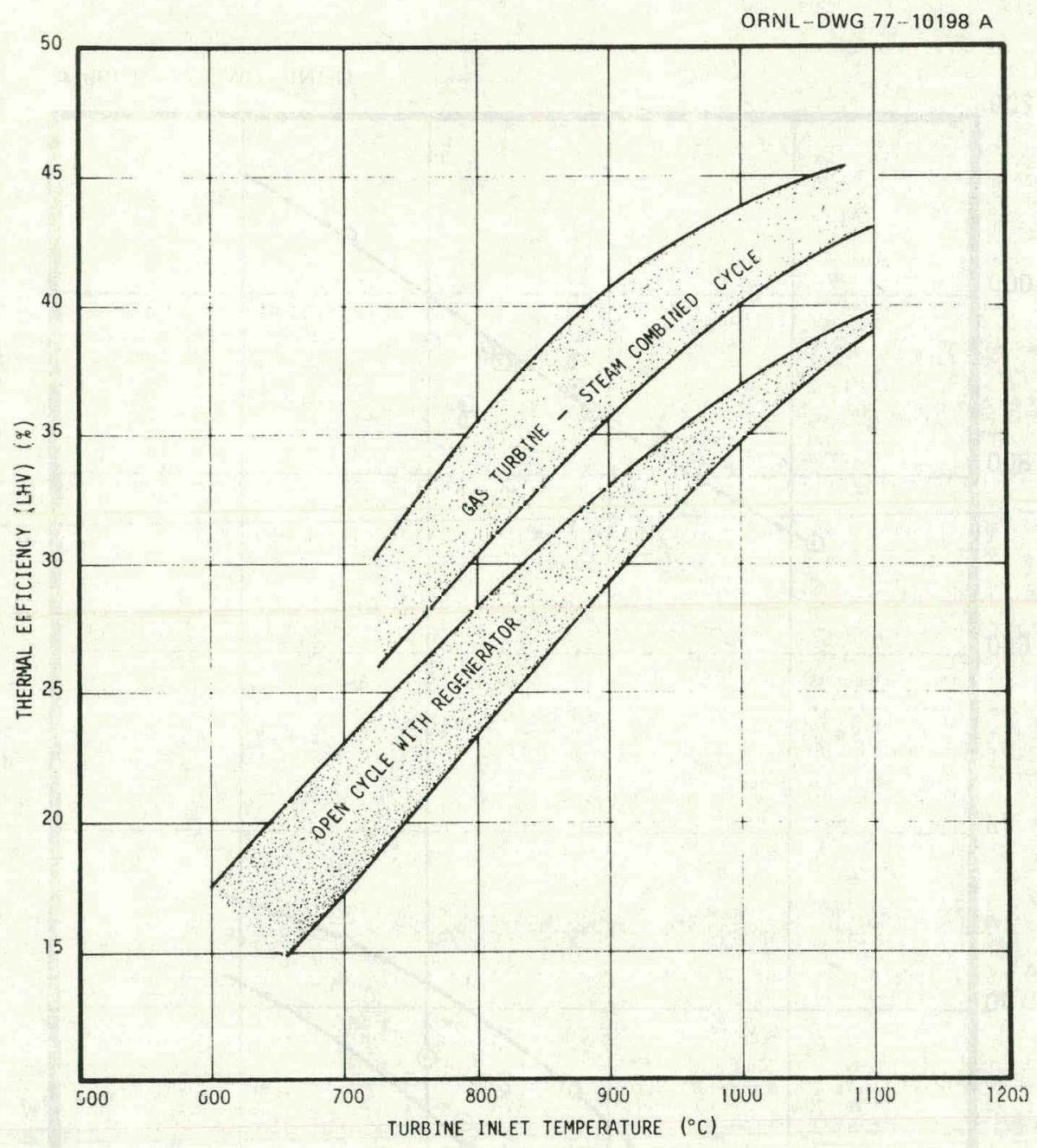

Fig. 14. Influence of the gas turbine inlet temperature on the thermal efficiency of open gas turbine cycles with regenerative and combined gas turbine-steam cycles.

combined cycle leads to substantially lower capital costs as compared to Lhe open-gas turbine cycle with regeneration.

\section{Fuel Flexibility}

Since the cost of the fuel is a significant fraction of the power cost, the cost and availability of suitable fuels greatly influence the use of gas turbines by utilities. The need for higher thermal efficiency requires that the gas turbine operate with the maximum inlet temperature 
that technology will allow. The choice of turbine inlet temperature, however, must be tempered by the effects of corrosion, erosion, and fouling that may result from contaminants in the fuel.

There are two basic types of fuel that a gas turbine may accommodate. These are the "clean" fuels, which include natural gas, distillate oils, and other derived fuels that are relatively free from contaminants; and the "heavy" fuels, which include crudes, residuals, heavy distillates, and coal-derived fuels contaminated with sulfur, chlorine, and trace metals.

The "clean" fuel, when protected from contamination before firing, provides a satisfactory fuel for the present state-of-the-art gas turbines. 56 The "heavy" fuels are unsuitable in the "as-received" condition and require cleaning before firing. The major contaminants that must be removed are those containing sodium, potassium, lead, and vanadium. The combined concentration of these four elements is usually limited to a maximum value of $3 \mathrm{ppm}$.

As the present sources of gas turbine fuels increase in cost and decrease in availability, the gas turbine fuels will be derived from coal, shale, and tar sands. These fuels will probably have different contaminants and firing characteristics than the petroleum-derived fuels and will in turn require turbine systcm modifications.

The properties of the derived fuels produced will represent a compromise between high fuel quality, practical economics, and the maximum utilization of natural resources.

\section{Reliability and Availability}

The reliability and availability of industrial and central station gas turbines have steadily improved since their introduction after World War II. Various individual utilities have presently accumulated operating experience with gas turbines of the order $10,000,000 \mathrm{hr} .{ }^{3,57}$

The application and general maintenance of the gas turbine are probably the two most important factors affecting the reliability and availability of the units. Edison Electric Institute made a study of equipment availability of 35 systems employing jet engines (1076 unft years) and 66 
systems employing gas turbines designed for utility operation (2183 unit years) in peaking service. ${ }^{58}$ The availability and starting reliability for the 3259 unit years of service were 86.5 and $81.8 \%$, respectively. The mean time between forced outages was $666 \mathrm{hr}$. Reducing the operating temperature of the gas turbine is reported to be the most reliable mode of preventive maintenance. In 1975, Commonwealth Edison reported a $\$ 250,000$ annual reduction in the maintenance costs for the operation of 65 gas turbines by reducing the turbine inlet temperature an average of $20^{\circ} \mathrm{C}$ below the rated value. ${ }^{59}$ Typical operating conditions ${ }^{60}$ for a peaking plant with air-cooled nozzles and blades are given in Table 3 .

Table 3. Operating constraints for a gas turbine peaking plant fueled with natural gas

\begin{tabular}{lcc}
$\begin{array}{l}\text { Operation } \\
\text { phase }\end{array}$ & $\begin{array}{c}\text { Turbine inlet } \\
\text { temperature } \\
\left({ }^{\circ} \mathrm{C}\right)\end{array}$ & $\begin{array}{c}\text { Operating hours/ } \\
\text { number of starts } \\
\text { between inspections }\end{array}$ \\
\hline Base & 1000 & $3000 / 600$ \\
Peaking & 1065 & $1000 / 200$ \\
Rescrve & 1100 & $250 / 100$ \\
\hline \multicolumn{2}{c}{$a_{\text {The inopection involves the inlet nuzzle and }}$} \\
the firct row of bladco. Lxpcetcd life at lase- \\
load conditions is estimated at 30,000 hr before a \\
major overhaul.
\end{tabular}

The time between major overhauls is heavily dependent on the fuel, employed. For a given turbine inlet temperature the best results are obtained with natural gas; with No. 2 fuel oil the time between major overhauls is reduced by $20 \%$ and with residual fuel. oil the time between overhauls must be reduced by around $60 \%$ relative to operation with natural gas. ${ }^{61}$ These reductions in life have stemmed from the corrosive effects of sulfur, vanadium, alkali metals, and chlorides in the fuel. The effects are complex and are heavily dependent on the particular combination of these contaminants. In practice, the usual procedure is to reduce the peak turbine inlet temperature for operation with the dirtier 
fuels. The operating life also depends on the incidence of starts and stops, which determine the amount of thermal strain cycling and hence influence the development of cracks, particularly in the combustors. Thus the operating life is much greater for gas turbines that operate continuously at their design loads in industrial service or are employed by utilities in base-load combined-cycle plants. A comparison of industrial and utility experience indicates that operation of the turbine at continuous base-load conditions with no more than one start per 1000 hr of operation would extend the inspection period from $\sim 3000 \mathrm{hr}$ to between 8000 and $30,000 \mathrm{hr}$, depending upon the cost to the utility of downtime.

Adequate preventive maintenance and crew training can increase the reliability and availability of both peaking and combined-cycle plants. A case history of the Vogtle plant of the Geogia Power Company indicates the value of preventive maintenance in a peaking plant. ${ }^{62}$ Over a period of two years the percentages for the reliability and availability improved from the mid-eighties to the mid-nineties as a result of a change in preventive maintenance from none to adequate. Corresponding improvements were experienced with combined-cycle plants as a result of crew training and experience. A combined-cycle power plant operated by the City of Clarksdale, Mississippi, showed an improvement in availability from approximately $70 \%$ at plant startup to $91.8 \%$ two years later. ${ }^{33}$ A combinedcycle plant operated in the Netherlands by the Dow Chemical Company has given results even better than the Clarksdale experience; ${ }^{6}$ the availability of the Dow plant improved from $88 \%$ at startup to $98.5 \%$ in a period of 3 to 5 years.

Integration of a gas turbine-steam combined-cycle plant with a coal gasification plant represents a new requirement for utility operators; that is, opcration of $A$ relatively complex chemical plant in addition to the electrical generation plant. This effective quantum jump in required operator ability will most probably result in a lower reliability and availability for the integrated plants during their formative years and a lunger period for shakedown than was experienced with the combined-cycle plants. The fuel quality from an integrated coal gasification plant will 
probably be such that the gas turbine life, reliability, and/or the allowable turbine inlet temperature will be reduced. The overall reliability and availability of the integrated plant must include the coal gasification plant, which will likely result in low values considering the complexity and severe corrosion conditions in the gasification system.

\section{CURRENT STATUS OF DEVELOPMENT}

As indicated in previous sections, the development of the gas turbine and the gas turbine-steam combined cycle are interrelated. The development status of the gas turbine is explored in companion reports in this series. $2,8,0$

The gas turbine-steam plants have been adopted by industrial and utility plants during the past 25 years to satisfy special local conditions. These conditions have included a need for high-temperature process heat, repowering existing sites, and the availability of low-cost highgrade fuel.18,19,49,50 Approximately 6,000,000 hr of operating experience with the gas turbine-steam combined-cycle plants in the U.S. has shown that with adequate preventive maintenance and sufficient crew training, the reliability and availability can reach the $95 \%$ range. ${ }^{33,63}$

With the present state of development of gas turbines, a combinedcycle plant operating with clean fuel can be constructed to yield a cycle efficiency of approximately $42 \% .^{39,40}$ However, in view of the present clean fuel shortage, coal must be considered as the principal fuel source for a rombined sycle.

The combination of a coal gasification plant and a gas turbine-steam combined cycle might have (in the near-term development stages) a s.yrip efficiency of approximately $40 \% .{ }^{32,36}$ The development of the combinted coal gasification and utility power plant to yield higher efficiencies will have to provide solutions to the problems of erosion, corrosion, and deposits at the relatively high temperature required by the gas turbine.

Construction of an experimental integrated high-pressure gasification plant and a combined gas turbine-steam electrical generation plant was started in 1969 by Steinkohlen-Elektrizität AG (STEAG) at the Kellermann Power Station at Lünen near Düsseldorf, Germany. ${ }^{37}$ A simplified flowsheet 
for the integrated gasification combined-cycle Lünen plant is shown in Fig. 3: The plant as designed was expected to have an efficiency of $36.9 \%$. The solids content of the fuel gas after the scrubber is specified to be 1 to $2 \mathrm{mg} / \mathrm{m}^{3}$.

The plant began operation in January 1973. Early operations encountered difficulties with the Lurgi gasifiers and with inadequate solids removal from the fuel gas by the two-stage water scrubber (i.e., particulate concentrations in the $50-\mathrm{mg} / \mathrm{m}^{3}$ range).${ }^{64}$ These and other problems continued to handicap operation, so that at the end of 1977 the plant was sti.1. not in regular service. This must be considered significant because the Lünen plant is the only one in the world in which a coal gasification plant has been integrated with a combined cycle. Further, the Lurgi gasifiers are widely regarded as the most reliable of the various coal gasification systems.

The Lurgi technology as represented in the Lünen plant has several inherent disadvantages: relatively low capacity, high steam consumption, inability to handle caking coals or large quantities of fine material, and inability to recycle tars. ${ }^{44}$ Various other coal gasification reactor types are under present investigation. Some of these are in the paper stage; others, such as the British Gas slagging gasifier located at Westfield, Scotland, and a two-stage gasifier operated by Westinghouse at Waltz Mill, Pennsylvania, are in the pilot stage.

A major problem limiting the life of coal gasifiers is $\mathrm{H}_{2} \mathrm{~S}$ corrosion in the reducing atmospheres that prevail. A recent paper ${ }^{65}$ on this subject indicates that one practical way to cope with the problem is to reduce the operating pressure in the gasifier. This reduces the partial pressure of the $\mathrm{H}_{2} \mathrm{~S}$, and this in turn reduces the corrosion rate. Figure 15 shows the corrosion rate for $0.5 \% \mathrm{Cr}$ steel as a function of both temperature and $\mathrm{H}_{2} \mathrm{~S}$ partial pressure. The corrosion rate for 300 series stainless steels is about $10 \%$ of that for the ferritic low-chromium alloy of Fig. 15.

Both Curtiss-Wright and General Electric, under contract with DOE, are investigating combined cycles in which coal is burned directly in a preseurized fluidized bed combustor. ${ }^{66}$ In the Curtiss-Wright system, (Fig. 16) the bed is cooled by air which is blended with the combustion 
ORNL $\cdots$ DWG $78-11396$

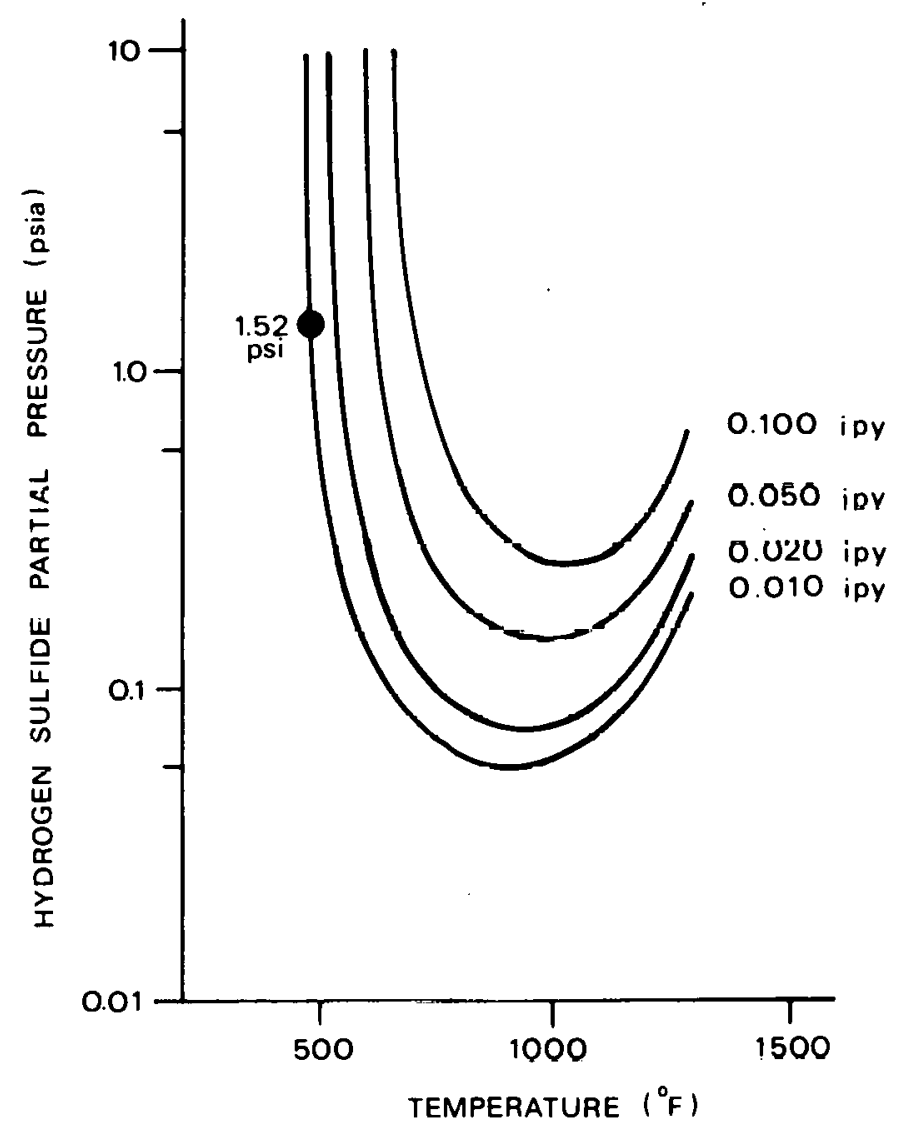

Fig. 15. Corrosion rate (in./year) of ferritic steel $(1.5 \% \mathrm{Cr})$ in hydrogen sulfide. 65

gases. ${ }^{67}$ The hot gas mixture is used to drive a turhine and a waste heat boiler. Approximately $70 \%$ of the power output is generated by the gas turbine and about $30 \%$ by the steam turbine.

In the General Electric approach, the fluidized-bed combustor is cooled by steam. The combustion gases from the pressurized furnare are used to drive a gas turbine, and the steam is used to drive a steam turbine. Approximately $70 \%$ of the power output is generated by the steam turbine and about $30 \%$ by the gas turbine.

These approaches utilizing the pressurized fluidized bed combustor have in common the problem of combustion gas cleanup (namely, sulfur and particulate removal). The detail designs of these systems will most probably reflect tradeoffs between the gas cleanup system and the ability 


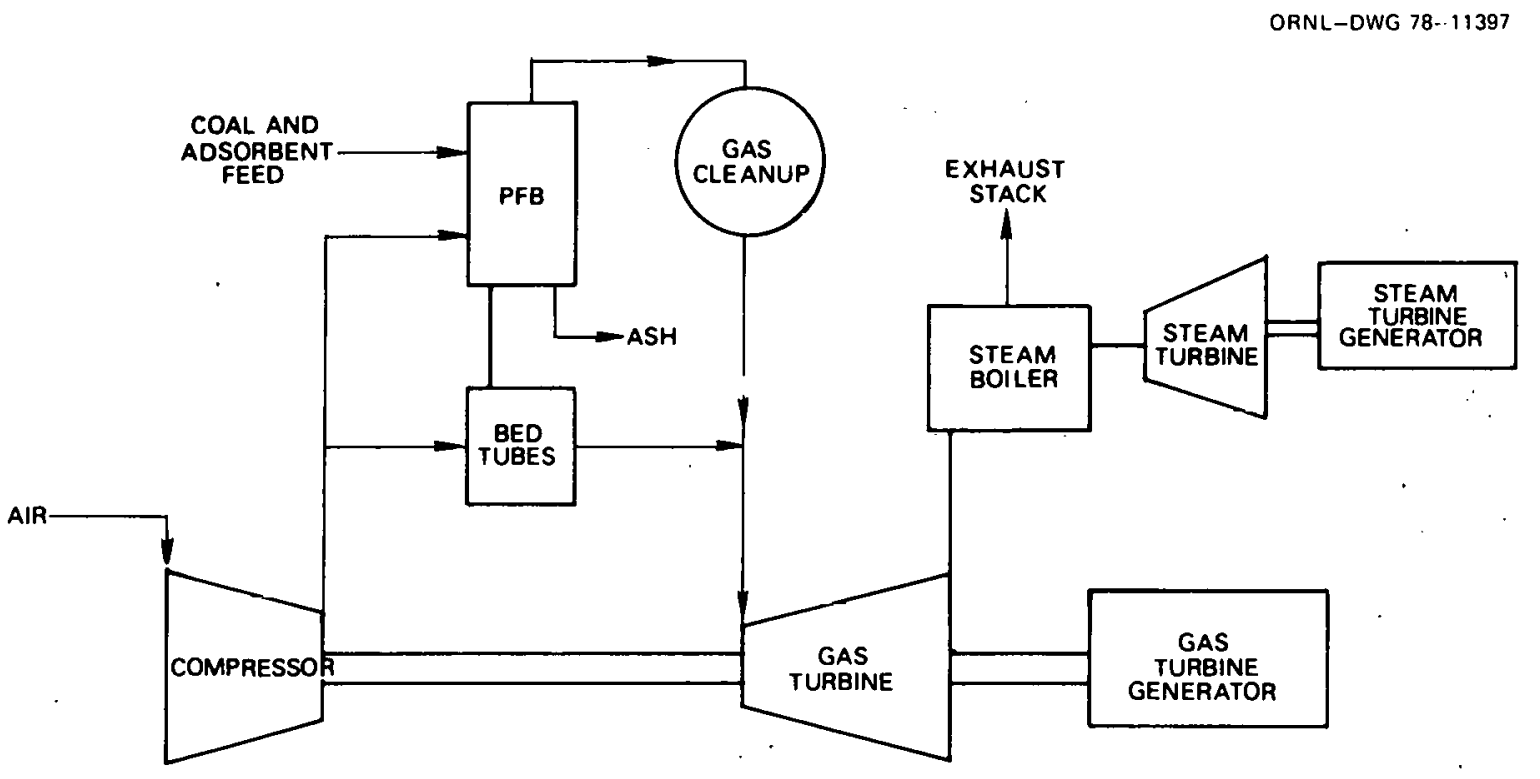

Fig. 16. Simplified flowsheet for the Curtiss-Wright pressurized fluidized bed-gas turbine-steam turbine combined-cycle power system. ${ }^{7}$

of turbine designs and construction materials to tolerate particulates in the gas stream.

Commercial gas turbines have been troubled by deposits stemming from dust in the inlet air stream. As a consequence, the engine manufacturers recommend that air filters be incorporated in the installation to keep the dust content to less than $\sim 2 \mathrm{ppm}$, and this is commonly found necessary in many urban environments. However, recent experience indicates that even tighter restrictions are required as the turbine inlet temperature is increased. One of the first strong indications of this was encountered in a 1974 gas turbine acceptance test at the Philadelphia Navy Yard. Substantial deposits were noted after only $\sim 200 \mathrm{hr}$ of operation under cycling conditions in which the turbine inlet temperature was in the $2100^{\circ} \mathrm{F}\left(1150^{\circ} \mathrm{C}\right)$ range about half the time. After $\sim 3000 \mathrm{hr}$ these deposits blocked cooling air discharge ports in the blades so that they were damaged by overheating. Subsequent investigation disclosed that the bulk of the deposit consisted of submicron-size $\mathrm{Fe}_{2} \mathrm{O}_{3}$ particles that entered the engine with the inlet air and had a particulate content of only $0.06 \mathrm{ppm}$. Further investigation disclosed that Philadelphia air was not dirtier in this respect than the air in most localities and that the deposits did not 
form when the nominal turbine inlet temperature was limited to $21800^{\circ} \mathrm{F}$ $\left(982^{\circ} \mathrm{C}\right)$. Note that the melting point of $\mathrm{Fe}_{2} \mathrm{O}_{3}$ is $2860^{\circ} \mathrm{F}\left(1570^{\circ} \mathrm{C}\right)$, which implies a sintering temperature of $22030^{\circ} \mathrm{F}\left(1110^{\circ} \mathrm{C}\right)$. This appears to be the reason that this type of deposit did not prove a problem until operations at a turbine inlet temperature of $2100^{\circ} \mathrm{F}\left(1150^{\circ} \mathrm{C}\right)$ were initiated. Note also that coal ash commonly contains $\sim 5 \% \mathrm{Fe}_{2} \mathrm{O}_{3}$. Thus, the implications of this experience are serious indeed. It may not be practicable to operate gas turbines in base-load service with turbine inlet temperatures above $\sim 1100^{\circ} \mathrm{C}\left(2012^{\circ} \mathrm{F}\right)$ because of diffiru1 ties with $\mathrm{Fe}_{2} \mathrm{O}_{3}$ deposits un turbine hiades. ${ }^{4}$

\section{REFERENCES}

1. A. P. Fraas, Comparison of Advanced Energy Conversion Systems on the Basis of Research and Development Experience, ORNL/TM-6259 (to be published).

2. A. P. Fraas, Summary of the Development of Steam Power Plants for Central Stations, ORNL/TM-6250 (to be published).

3. A. P. Fraas and A. S. Thompson, Research and Development Experience and Current Status of Development of Open-Cycle Gas Turbines, ORNL/ TM-6251 (to be published).

4. M. E. Lackey, Summary of the Research and DeveZopmert Effort on Opencycle Coal-Fired Gas Turbines, ORNL/TM-6253 (to be published).

5. A. P. Fraas, Summary of the Research and Development Effort, on. Air and Water-Cooling of Gas Turbine Blades, ORNL/TM-6254 (to be pub1ished).

6. A. P. Fraas and W. M. Wells, Jr., Summary of the Research and Development Effort on Ceramic Gas Turbines, ORNL/TM-6255 (to be published).

7. A. P. Frais, Sumbry of the liesearah and vevelupmerl Ef'furt on ClosedCycle Gas Turbines, ORNL/TM-6237 (to be published).

8. A. P. Fraas, Summary of the Work on the Supercritical $\mathrm{CO}_{2}$ Cycle, ORNL/ TM-6236 (to be published).

9. A. P. Fraas, Summary of the Research and Development Effort on Alkali Metal Vapor Cycles, ORNL/TM-6256 (to be published).

10. F. J. Young, Summary of the Research and DeveZopment Effort on OpenCycle MHD Systems, ORNL/TM-6257 (to be published). 
11. A. P. Fraas, Summary of the Research and Development Effort on Fuel CelZs, ORNL/TM-6258 (to be published).

12. J. F. Lee, Theory and Design of Steam and Gas Turbines, McGraw-Hill Book Company, Inc., p. 29, 1954.

13. S. A. Moss, "Gas Turbines and Turbosuperchargers," Trans. ASME 66, 351-71 (July 1944).

14. Adolph Meyer, "The Velox Steam Generator - Its Possibilities as Applied to Land and Sea," Meoh. Eng. 57, 469 (1935).

15. H. Pfenninger and G. Yannakopoulos, "Steam Power Stations with Pressure-Fired Boilers," Brown Boveri Review 66, 309 (July/August 1975).

16. A. E. Pew, Jr., "Operating Experience with the Gas Turbine-Report on Use as Propulsion Equipment for Axial Air Compressors at Sun Oil Refineries," Mech. Zing. 67, 594-98 (1945).

17. Curt Keller, "The Escher Wyss-AK-Closed-Cycle Turbine, Its Actual Development and Future Prospects," Trans. ASME 68, 791 (November 1946).

18. J. W. Blake, "Combination Gas Turbine-Steam Turbine Unit - Performance of Installation Burning Natural Gas at Belle Isle Station," Mech. Eng. 73, 14-16 (January 1951).

19. "Design Features of Typical Stationary Gas Turbine Installed in Central Stations," Power, pp. S-10 and S-11, October 1963.

20. "Report on 50 Utility Projects Covers Base Load, Peaking and Standby Units," Power, pp. S-14 and S-15, October 1965.

21. "Many Utility Gas Turbines Serve for Peaking and Standby Purposes," Power, pp. S-22 through S-25, October 1969.

22. "Single-shaft Gas Turbines Range in Size from $750 \mathrm{~kW}$ to $58 \mathrm{MW}, "$ Power, pp. S-14 and S-15, October 1970 .

23. "Most Gas Turbines Vented to Atmosphere, Heat Is Not Removed," Power, pp. S-26 and S-27, Nnvemher 1971.

2/. "W1th $4000 \mathrm{MW}$ Ordered through June, This Could be Record Year for Sales," Power, pp. S-11 through S-15, November 1972.

25. "Repowering Experience Growing Rapidly in Utility Plants," Power, pp. S-9 through S-13, November 1973.

26. "Oil-Short Utilities Plan for the Future," Power, pp. S-14 through S-16, November 1974 . 
27. "Borescopes Help Boost Turbine Availability," Power, pp. S-15 through S-17, November 1975.

28. "Overseas Orders Keep Manufacturers Busy," Power, pp. S-17 through S-19, November 1976.

29. "Special Cycle Installations and Orders," Gas Turbine World, Pricing and Production Forecast - 1976, pp. 13-1 through 13-5, June 1976.

30. H. F. Hartman, D. E. Reagan, and J. P. Belk, Low BTU Coal Gasification Processes, Vols. 1 and 2, ORNL/ENG/TM-13 (to be published).

31. Comparative Evaluation of High and Low Temperature Gas Cleaning for

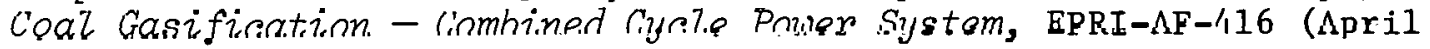
$19.77)$.

32. K. Chandra et a1., Economic Studies of Coaz Gasification Combined Cycle Systems for Electric Power Generation, EPRI-AF-642 (January 1.978).

33. F. H. Kindl and J. Haley, "Design and Operation of a 26-MW Stag Plant," ASME Paper No. 75-GT-18, March 1975.

34. D. J. Amos, R. M. Lee, and R. W. Foster-Pegg, Energy Conversion AZternatives Study (ECAS) Westinghouse Phase I-Final Report, Vol. V, Combined Gas-Steam Turbine Cycles, NASA CR-134941, Vo1. V, Westinghouse Electric Corporation Research Laboratories (February 1976).

35. J. C. Corman and G. R. Fox, Energy Conversion Altematives Study (ECAS), General Ellectric Phase II Final Report, NASA-CR-134949, Vol. 1 (December 1976).

36. R. W. Foster-Pegg and H. L. Jaeger, "Low Btu Gas Powering of Combined Cycle Plants," American Power Conference, Chicago,'I11., Apr. $2.0,1976$.

37. K. Bund, K. A. Henney, and K. H. Krieb, "Combined Gas/Steam-Turbine Generating Plant with Bituminous-Coal High-Pressure Gasification Plant in the Kellermann Power Station at Lünen," STEAG Anlagentechnik, 1970.

38. R. W. Foster-Pegg, Westinghouse, personal communication to A. P. Fraas, Mar. 22, 1978.

39. C. H. Armstrong, "Effect of Recent Advancements in Gas Turbine Technology on Combined-Cycle Efficiency," ASME Paper No. 74-PWR-8, September 1974 .

40. S. V. Lee and W. E. Young, "Gas Turbine Hot-Stage Parts in Aggressive Atmospheres," Joumal of Engineering for Power, p. 540, October 1976. 
41. A. D. Foster, H. Doerning, and J. W. Hickey, Fuel Flexibility in Heavy-Duty Gas Turbines, General Electric Company report GER-2222J (1974).

42. D. F. Crego, Remarks on "Gasified Coal Combined Cycle Systems," Panel Presentation, Session 44, ASME 20th Annual International Gas Turbine Conference, Houston, Tex., March 1975.

43. G. V. McGur1 and J. F. Kamody, "Koppers-Totzek Gasification for Electric Power Generation," ASME Paper No. 76-JPGC-FU-1, September 1976.

44. R. C. Rittenhouse, "Clean Fuels from Coal: Finding the Right Combination," Power Engineering, p. 36, October 1977.

45. A. M. Robin, Hydrogen Production from Coal Liquefaction Residues, EPRI AF-233 (December 1976).

46. "Increase Gas-Turbine Efficiency," Power, pp. 43-45, January 1974.

47. "Electrical Generator Drives," Industrial Gas Turbine Handbook \& Directory, pp. 50-63, 1976.

48. C. Seippel and R. Bereuter, "The Theory of Combined Steam and Gas Turbine Installations," Combustion, pp. 30-41, September 1961.

49. "Practical Examples of Ut1lizing the Waste Heat of Gas Turbines in Combined Installations," Bulletin No. 2868E, Brown, Boveri \& Co., Ltd. , 1965.

50. L. Zünd, "The Combined Gas-and-Steam Turbine Plant of Electricité Neuchateloise S.A.," Combuction, Pp. 33-39, May 1969.

51. J. 0. Stephens and V. P. Buscemi, "100, 200, and 400-MW Steam and Gas-Turbine Power Plants," ASME Paper No. 63-PWR-18, September 1963.

52. F. W. L. Hubert, "Large Combined Cycles for Utilities," ASME Paper No. 70-GT-21, May 1970.

53. P. A. Berman and G. E. Baker, "Combined Cycle Packaged Power Plant," Gas Turbine Intemational, pp. 34-38, January-February 1971.

54. C. H. Armstrong, "Effect of Recent Advancements in Gas Turbine Technology on Combined-Cycle Efficiency," ASME Yaper No. 74-PWR=8, June 1974 .

55. Combined Cycle Power Plant Capital Cost Estimates, EPRI, AF-610 (December 1977).

56. J. P. Patterson, "Operating and Maintenance Experience for Base Load Gas Turbines Using Heavy Fuels - A Case Study," ASME Paper No. 75GT-74, Marsh 1975. 
57. "Gas Turbine Electric Plant Construction Cost and Annual Production Expenses - First Annual Supplement - 1973," F.P.C. S-254, Federal Power Commission, 1973.

58. "Report on Equipment Availability for the Ten Year Period, 1965-1974," EEI Publication No. 75-50, issued November 1975 by Equipment Availability Task Force of the Prime Movers Committee, Edison Electric Institute.

59. R. W. Smock, "Utilities Battle Gas Turbine Maintenance Cost," Electric Light and Power, pp. E/G-9, May 26, 1975.

60. William Averaby, Tennessee Valley Authority, personal communication ro M. L. Lackey, June 1975.

61. W. L. Wright, Westinghouse Electric Corporation, personal communication to A. P. Fraas, July 26, 1973.

62. W. H. Nicholls and R. H. Witt, "Effect of Maintenance on Gas Turbine Reliability," ASME Paper No. 76-GT-68, March 1.976.

63. W. Moldenhauer and C. P. Van der Vizver, "Gas Turbine Industrial Power Generation Experience at Dow Chemical Terneuzen Plant," Diesel \& Gas Turbine Progress Worlduide, p. 10, March 1975.

64. A. P. Fraas, v1sit to Lïnen plant, Sept. 28, 1973.

65. P. B. Probert et a1., "Corrosion in Reducing Atmospheres - A Designer's Approach," paper presented to the International Symposium on Corrosion and Deposits, Henniken, N.H., June 26-July 1, 1977.

66. J. Papamarcos, "Combined Cycles and Refined Coal," Power Engineering, pp. 34-42, December 1976.

67. S. Moskowitz, "Pressurized Fluidized Bed Pilot Electric Plant," T2ºceedings of the Fluidized Bed Combustion Technology Exchange Workshop, CUNH-7/U44/-P-1, Vol. 1 (April 1977). 
Appendix A

COMBINED-CYCLE POWER PLANT INSTALLATIONS

Table A-1 gives representative gas turbine-steam combined-cycle power plants designed for electric utility power generation that were in operation or on order as of June 1976. The listing does not include process applications (where the steam is used in the process and not for electric power generation).

The data in Table A-1, taken from Ref. 29, were derived from data published during the 1966 to 1976 period. The information was crosschecked for accuracy against manufacturer's installation 1ists. 
Table A-1. Ccmbined-cycle pover plant installations as of June L, 19:6 (Ref. 29)

\begin{tabular}{|c|c|c|c|c|c|c|c|c|c|}
\hline \multirow[b]{2}{*}{ Customer and site } & \multicolumn{3}{|c|}{ Gas turbine } & \multicolumn{2}{|c|}{ Jombined-cycle } & \multirow[b]{2}{*}{ Order } & \multirow[b]{2}{*}{$\begin{array}{l}\text { Operation } \\
\text { time }\end{array}$} & \multirow[b]{2}{*}{ Fuel } & \multirow[b]{2}{*}{ Comments } \\
\hline & Mfr. & $\begin{array}{l}\text { CLtput } \\
\text { (MW) }\end{array}$ & $\begin{array}{l}\text { No, ce: } \\
\text { units }\end{array}$ & $\begin{array}{l}\text { Jutput } \\
\text { (MW) }\end{array}$ & $\begin{array}{l}\text { No. of } \\
\text { plants }\end{array}$ & & & & \\
\hline \multicolumn{10}{|l|}{ Austria } \\
\hline Hohe Wand & KWU & 12 & 1 & 80 & 1 & 1962 & 1965 & $\mathrm{G} e \mathrm{~s}$ & $41.9 \%$ efficiency LCV \\
\hline Timelkam Lir.z & $\mathrm{BBC}$ & 70 & 1 & & 1 & 1972 & 1975 & $G e s-0=1$ & \\
\hline N.E. Ag Theiss & Stal & 74 & 1 & & 1 & 1973 & 1976 & $\mathrm{G} e . \mathrm{s}$ & \\
\hline Simmering Vienna & KWU & 73 & 1 & $\$ 46$ & 1 & 1974 & 1977 & Ges & $46.6 \%$ efficiency LCV \\
\hline Tiwag & KWU & 66 & 1 & & 1 & 1975 & 1978 & Ges-o:1 & \\
\hline \multicolumn{10}{|l|}{ Belgium } \\
\hline Interbrabant & ACEC & -92 & 1 & $1 \geqq 5$ & 1 & 1974 & 1976 & $0=1$,gas & \\
\hline Socolie & ACEC & 68 & 2 & $\subseteq 8$ & 1 & 1975 & 1977 & Gäs & \\
\hline \multicolumn{10}{|l|}{ Czechoslovakia } \\
\hline Bratislava CSSR & Prvni & 25 & 1 & & & 1966 & 1969 & $0=1$ & City heating \\
\hline State Elec. Bratislave & Prvni & 1 & 1 & $=0$ & 1 & 1956 & 1959 & Gas. & \\
\hline \multicolumn{10}{|l|}{ Finland } \\
\hline Nesteoy & Fiat & 32 & 1 & & 3 & 1964 & 1976 & & District heating \\
\hline LKS Lahti & Stal & 12 & 1 & & 1 & 1968 & 1970 & & District heating \\
\hline \multicolumn{10}{|l|}{ France } \\
\hline Vitry Sur Seine I, II & $\mathrm{BBC}$ & 42 & 1 & $3 \approx 2$ & 2 & 1967 & $1970 / 7=$ & Gas & $42.0 \%$ efficiency LCV \\
\hline Emile Hachet & & 50 & 3 & $3<4$ & 1 & 1970 & 1974 & Coke sas & \\
\hline \multicolumn{10}{|l|}{ Germany } \\
\hline Stadtwerke Munich & KWU & 42 & 2 & & & 1960 & 1964 & Gas:oil & District heating \\
\hline Stadtwerke Brunswiz & KWU & 21 & 1 & & & 1961 & 1964 & Gas.oil & District heating \\
\hline Altbach II & KWU & 50 & 1 & 280 & 1 & 1968 & 1971 & $0 \mathbf{i} 1$ & $38.2 \%$ ef ficiency LCV \\
\hline Essen-Steag-Lunen & KWU & 74 & 2 & 1.0 & 1 & 1969 & 1972 & Cra_- jas/oil & Coal gasification \\
\hline Gersteinwerk Vew & KWU & 55 & 1 & 400 & 4 & 1970 & $1973 / 79$ & G.as & \\
\hline Emden IV NWK & KWU & 55 & 1 & 455 & 1 & 1970 & 1973 & Gas & $43.0 \%$ efficiency LCV \\
\hline Robert Frank PREAG & BBC & 55 & 1 & $5=0$ & 1 & 1970 & 1973 & Gas & \\
\hline Marbach, EVs & BBC & 55 & 1 & 325 & 1 & 1970 & 1973 & Gas'oil & \\
\hline CWH PLT I, II & KWU & 55 & 1 & 195 & 2 & 1970 & 1974 & Gas & \\
\hline VEW Emsland $A$ & KWU & 55 & 1 & 400 & 1 & 1970 & 1973 & Gas & District heating \\
\hline Stadtwerke Munich & KWU & 50 & 1 & & 2 & $\cdot 1970$ & 1973 & Gas'oil & District heating \\
\hline Franken I GFAG & KWU & 35 & 1 & 400 & 1 & 1971 & 1975 & Gas & \\
\hline GK Weser, Veltheim & $\mathrm{BBC}$ & 59 & 1 & 350 & 1 & 1971 & 1975 & Gas'oil & \\
\hline VEW Emsland B,C & KWU & 55 & 1 & 400 & 2 & 1971 & 1975 & Gistoil & \\
\hline Stadtwerke Jusseldorf & BBC & 127 & 2 & 4.10 & 1 & 1971 & 1977 & Gastoil & \\
\hline Stadtwerke Juisburg III & KWU & 33 & 1 & 173 & 1 & 1972 & 1975 & Gas & District heating \\
\hline Wiesbaden K' Mainz & & 55 & 1 & $3 \geq 5$ & 1 & 1972 & 1976 & oil & \\
\hline STW Saarbru=ken & Alsth & 22 & 1 & 35 & 1 & 1972 & 1974 & Gaslail & \\
\hline Bewag-Berlin & Al sth & 39 & $\mathbf{1}$ & & 3 & 1974 & 1976 & Gasloil & . \\
\hline \multicolumn{10}{|l|}{ Italy } \\
\hline Cornigliano-Genova & BBC & 15 & 1 & & 1 & 1960 & $\dot{i} 963$ & Blast furn. gas & \\
\hline
\end{tabular}


Table A-1 (continued)

\begin{tabular}{|c|c|c|c|c|c|c|c|c|c|}
\hline \multirow[b]{2}{*}{ Customer and site } & \multicolumn{3}{|c|}{ Gas turbine } & \multicolumn{2}{|c|}{ Combined cycle } & \multirow[b]{2}{*}{ Order time } & \multirow[b]{2}{*}{$\begin{array}{l}\text { Operation } \\
\text { time }\end{array}$} & \multirow[b]{2}{*}{ Fuel } & \multirow[b]{2}{*}{ Comments } \\
\hline & Mf $\dot{r}$ & $\begin{array}{l}\text { Output } \\
\text { (MW) }\end{array}$ & $\begin{array}{l}\text { No. of } \\
\text { units }\end{array}$ & $\begin{array}{l}\text { Output } \\
\text { (MW) }\end{array}$ & $\begin{array}{l}\text { No. of } \\
\text { plants }\end{array}$ & & & & \\
\hline \multicolumn{10}{|l|}{ Jạpan } \\
\hline $\begin{array}{l}\text { Maruzumi Paper Co } \\
\text { Sakaide Stikoku Elec Ewr }\end{array}$ & $\begin{array}{l}\text { MHI } \\
\text { MHI }\end{array}$ & $\begin{array}{l}16 \\
30\end{array}$ & $\begin{array}{l}1 \\
1\end{array}$ & $\begin{array}{r}33 \\
225\end{array}$ & $\begin{array}{l}1 \\
1\end{array}$ & $\begin{array}{l}1965 \\
1966\end{array}$ & $\begin{array}{l}1968 \\
1970\end{array}$ & $\begin{array}{l}\text { Resid. oil } \\
\text { Coke gas }\end{array}$ & $42.1 \%$ efficiency LCV \\
\hline $\begin{array}{l}\text { Mexico } \\
\quad \text { Comision Fed Electricidad }\end{array}$ & W & 140 & 2 & 260 & 3 & 1973 & $1975 / 76$ & oil & \\
\hline $\begin{array}{l}\text { Netherlands } \\
\text { Amercentralie-PNEM } \\
\text { Royal Dutch Salt } \\
\text { Geertruiden-PNEM } \\
\text { De L'Azote-Sluiskil }\end{array}$ & $\begin{array}{l}\text { BBC } \\
\text { GE } \\
\text { BBC } \\
\text { Fiat }\end{array}$ & $\begin{array}{l}16 \\
17 \\
76 \\
30\end{array}$ & $\begin{array}{l}2 \\
1 \\
1 \\
1\end{array}$ & $\cdot$ & $\begin{array}{l}1 \\
1 \\
1 \\
1\end{array}$ & $\begin{array}{l}1968 \\
1969 \\
1973 \\
1974\end{array}$ & $\begin{array}{l}1971 \\
1972 \\
1976 \\
1976\end{array}$ & $\begin{array}{l}\text { Gas/oil } \\
\text { Gas } \\
\text { Cas } \\
\text { oil/gas }\end{array}$ & Repowering steam turbine \\
\hline $\begin{array}{l}\text { Panama Canal } \\
\text { Canal Company Ballboa }\end{array}$ & W & 24 & 2 & ' & 1 & 1962 & 1963 & oil & Repowering steam turbine \\
\hline $\begin{array}{l}\text { Puerto Rico } \\
\text { Water Resources Authority }\end{array}$ & GE & 180 & 4 & 310 & 2 & 1974 & $1976 / 77$ & $0 i 1$ & GT operation 1975 \\
\hline $\begin{array}{l}\text { S. Korea } \\
\text { Korea Electric }\end{array}$ & GE & 260 & 4 & 396 & 2 & 1976 & 1978 & oil & \\
\hline $\begin{array}{l}\text { U.S.S.R. } \\
\text { Nevinomyssk }\end{array}$ & Len & 37 & 1 & 200 & 1 & 1965 & 1969 & Gas & \\
\hline $\begin{array}{l}\text { Venezuela } \\
\quad \text { Cadafe El Tabazo }\end{array}$ & wCan & 15 & 1 & & 1 & 1970 & 1972 & oil & Repowering steam turbine \\
\hline $\begin{array}{l}\text { Yugoslavia } \\
\text { Toplana }\end{array}$ & Fiat & 90 & 3 & & 1 & 1961 & 1965 & Naphtha/resid. & District heating \\
\hline Ur.ited States & & & & & & & & & \\
\hline Apache Arizona & GE & 11 & 1 & 93 & 1 & 1960 & 1963 & NG & $38.5 \%$ efficiency LHV \\
\hline $\begin{array}{l}\text { City Fairbanks Alaska } \\
\text { City Fairbanks Alaska }\end{array}$ & $\mathrm{GE}$ & $\begin{array}{l}5 \\
6\end{array}$ & 1 & & 1 & 1961 & 1963 & oil & Repowering steam turbine \\
\hline $\begin{array}{l}\text { City Fairbanks Alaska } \\
\text { Oklahoma Gas \& Elec }\end{array}$ & $\begin{array}{l}\mathrm{GE} \\
\mathrm{GE}\end{array}$ & $\begin{array}{r}6 \\
23\end{array}$ & $\begin{array}{l}1 \\
1\end{array}$ & $\begin{array}{r}18 \\
216\end{array}$ & $\begin{array}{l}1 \\
1\end{array}$ & $\begin{array}{l}1961 \\
1961\end{array}$ & $\begin{array}{l}1963 \\
1963\end{array}$ & $\begin{array}{l}\text { Oil } \\
\text { NG }\end{array}$ & $39.7 \%$ efficiency ICV \\
\hline Chugach Electric Alaska & W & 7 & 1 & & 1 & 1962 & 1963 & ail & Repowering steam turbine \\
\hline Community P.S. Mexico & GE & 12 & 1 & & 1 & 1963 & 1965 & NG & \\
\hline Empire Riverton Kansas & $\mathrm{W}$ & 13 & 1 & 50 & $i$ & 1963 & 1964 & oil & \\
\hline West Texas Utilities & $\mathrm{W}$ & 25 & 1 & 110 & $i$ & 1962 & 1965 & NG & 40.7\% efficiency LCV \\
\hline Dow Chemical Texas & $\mathrm{W}$ & 29 & 1 & & 3 & $1964 / 65$ & $1966 / 67$ & NG & \\
\hline Southland Paper Iexas & GE & 15 & 1 & 46 & 2 & $1964 / 66$ & $1966 / 68$ & NG & \\
\hline University Texas & $\mathrm{W}$ & 13 & 1 & & 1 & 1965 & 1967 & NG & \\
\hline Wolverine REA Michigan & $\mathrm{GE}$ & 15 & 1 & 23 & 1 & 1965 & 1968 & oil & \\
\hline Ot tawa Wer \& Light Kansas & GE & 7 & $i$ & 12 & 1 & 1966 & 1968 & NG & \\
\hline City Wyandotte Michigan & $\mathrm{W}$ & 15 & 1 & & 1 & 1967 & 1969 & Gas/oil & Repowering steam turbine \\
\hline Dow Chemical Texas & $\mathrm{W}$ & 44 & 1 & & 6 & $1967 / 69$ & $1969 / 72$ & NG & \\
\hline
\end{tabular}


Table A-1 icontinued)

\begin{tabular}{|c|c|c|c|c|c|c|c|c|c|}
\hline \multirow[b]{2}{*}{ Customer and site } & \multicolumn{3}{|c|}{ Ga:s turbine } & \multicolumn{2}{|c|}{ Conbined-rycle } & \multirow[b]{2}{*}{ Order time } & \multirow{2}{*}{$\begin{array}{l}\text { Operation } \\
\text { time }\end{array}$} & \multirow[b]{2}{*}{ Fuel } & \multirow[b]{2}{*}{ Comments } \\
\hline & Mfr. & $\begin{array}{l}\text { Dutput } \\
\text { (MW) }\end{array}$ & $\begin{array}{l}\text { No. of } \\
\text { units }\end{array}$ & $\begin{array}{l}\text { Output } \\
\text { (MW) }\end{array}$ & $\begin{array}{l}\text { No. of } \\
\text { Jlants }\end{array}$ & & & & \\
\hline \multicolumn{10}{|l|}{ United States (continued) } \\
\hline City Clarksdale Mississiopi & $\mathrm{GE}$ & 18 & 1 & 26 & 1 & 1968 & 1971 & NG & 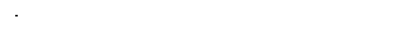 \\
\hline Gulf Coast Aluminum & Turbd & 53 & 3 & & 1 & 1968 & 1970 & Noc & \\
\hline Duke Power Riverbend N.C. & TPM & 120 & 8 & 276 & 1 & 1969 & 1970 & Gas/oil & Repowering steam turbine \\
\hline Duke Power Buck, N.C. & TPM & 120 & 6 & 185 & 1 & 1969 & 1970 & Gas/oil & Repowering steam turbine \\
\hline City Hutchinson Minnesota & $\mathrm{GE}$ & 7 & 1 & 12 & 1 & 1970 & 1972 & oil & \\
\hline Dow Chemical Texas & $\mathrm{w}$ & 60 & 1 & & 2 & 1970 & 1972 & NG & \\
\hline GE Lynn, Mass & $\mathrm{GE}$ & 21 & i & 35 & 1 & 1970 & 1972 & Gas/oil & \\
\hline Kansas Power \& Light & GE & 43 & 1 & 60 & 1 & 1970 & 1972 & & \\
\hline City Detroit Michigan & $\mathrm{w}$ & 30 & 1 & & 1 & 1971 & 1973 & Gas/oil & Repowering steam turbine \\
\hline Houston Light \& Power & GE & 247 & 4 & 550 & 2 & 1971 & 1974 & NG & GT operation in 1973 \\
\hline Public Service Oklahoma & $\mathrm{w}$ & 130 & 2 & 250 & 1 & 1971 & 1974 & $\sqrt{G}$ & \\
\hline St. Joe Power \& Light & w & 60 & $i$ & & 1 & 1971 & 1972 & Cil & Repowering steam turbine \\
\hline Central Iowa Co-Op & $\mathrm{w}$ & 30 & 1 & & 1 & 1972 & 1973 & Cil & Repowering steam turbine \\
\hline Central Vermont Pub Serv & $\mathrm{w}$ & 130 & 1 & 260 & 1 & 1972 & & Cil & Canceled \\
\hline Duquesne Light Penn & GE & 180 & 3 & 320 & 1 & 1972 & 1973 & Cil & \\
\hline El Paso Texas & w & 130 & 2 & 260 & 1 & 1972 & 1976 & & . \\
\hline GPU Jersey Central & W & 130 & 2 & 260 & 1 & 1972 & & Cil & Canceled \\
\hline Jacksonville Elec Auth & w & 120 & 2 & 245 & 2 & 1972 & 1980 & Cil & GT operation in 1973 \\
\hline Jacksonville Elec Auth & GE & 200 & 3 & 400 & 1 & 1972 & 1980 & Cil & GT operation in 1974 \\
\hline Jersey Central & $\mathrm{GE}$ & 198 & 4 & 340 & 1 & 1972 & 1977 & Cil & GT operation in 1973 \\
\hline Louisiana Power \& Light & GE & 126 & 2 & 208 & 1 & 1972 & 1974 & NG & GT operation in 1973 \\
\hline Ohio Edison & GE & 130 & 2 & 235 & 1 & 1972 & 1974 & Ci1 & GT operation in 1973 \\
\hline Pub Service E\&G New Jersey & TPM & 85 & 4 & 125 & 1 & 1972 & 1975 & FG & \\
\hline So Cal Edison & Turbd & 350 & 6 & & 1 & 1972 & 1976 & AG/oil & Repowering steam turbine \\
\hline So Cal Edison & W & 140 & 2 & 260 & 2 & 1972 & 1979 & $N G$ & In storage \\
\hline So Cal Edison & GE & 360 & 5 & 450 & 3 & 1972 & & (iil & Canceled \\
\hline Southwest Fub Serv Texas. & W & 30 & 1 & & 1 & 1972 & 1973 & NG & Repowering steam turbine \\
\hline Arizona Public Service & GE & 55 & $i$ & 83 & 1 & 1973 & 1976 & FG & \\
\hline Braintree Massachusetts & Turbd & 60 & 1 & 90 & 1 & 1973 & 1976 & (iil & \\
\hline C-W Wood-Ridge New Jersey & $\mathrm{CW}$ & 13 & 1 & 20 & 1 & 1973 & 1975 & rEg & Converted to gasified coal \\
\hline Florida Power \& Light & w & 140 & 2 & 260 & 2 & 1973 & 1976 & ciil & \\
\hline Pacific Gas \& Elec & TPM & 50 & 1 & & 1 & 1973. & 1975 & $\Delta G$ & \\
\hline Portland Gen Elec Oregon & GE & 395 & 6 & 500 & 1 & 1973. & 1977 & (iil & GT operation in 1974 \\
\hline Salt River Arizona & $\mathrm{GE}$ & 55 & 1 & 80 & 3 & 1973. & 1974 & EG & \\
\hline San Diego Gas \& Elec & Turbd & 240 & 4 & 350 & 1 & 1973. & & $\Delta G$ & Canceled \\
\hline Central lowa Co-Op & W & 30 & 1 & & 1 & 1974. & 1975 & Gas/oil & \\
\hline Dow Chemical Texas & $\mathrm{GE}$ & 67 & 1 & & 1 & 1974. & 1976 & $\Delta G$ & \\
\hline Burbank California & TPM & 50 & 1 & & 1 & 1975 & 1976 & Gas/oil & Repowering steam turbine \\
\hline Chugach Alaska & Turbd & 60 & $\overline{1}$ & & $\overline{1}$ & 1975 & 1976 & oil & Repowering steam turbine \\
\hline So Cal Ećison & $\mathrm{GE}$ & 264 & 5 & 416 & 3 & 1975 & 1985 & $0 i 1$ & GT operation in $1980 / 81$ \\
\hline Western Farmers Oklahoma & GE & 98 & 1 & & 3 & 1975 & 1977 & oil. & \\
\hline Pacific Gas \& Elec & $?$ & 286 & 4 & 396 & 2 & 1976 & 1980 & $0 i 1$ & Contract not awarded yet \\
\hline
\end{tabular}




\author{
Appendix B \\ POTENTIAL FOR FUTURE DEVELOPMENT
}

\title{
Theoretical Considerations
}

One way to consider the theoretical aspects of the performance of separate gas and steam turbine cycles and of combinations of these is to plot their cycles on a temperature-entropy diagram and compare the results with those of the theoretical Carnot cycle. One statement of the second law of thermodynamics is that no real power plant cycle operating between given upper and lower temperature limits can have an efficiency greater than that of a Carnot cycle operating between the same temperature limits. The performance of the theoretical Carnot cycle therefore represents the upper limit to the performance of real cycles. Figure B-1 shows schematically a Carnot cycle, in which heat is added at the highest temperature of the gas turbine cycle and rejected at ambient temperature. The highest temperature is designated $\mathrm{T}_{2}$ and the ambient temperature $T_{1}$. On the Carnot cycle diagram, all the area under the line $\mathrm{T}_{2}$ and above the temperature of absolute zero $\mathrm{T}=0$ represents the heat added to the cycle from the high-temperature source, and all the area below the line $T_{1}$ and above absolute zero represents the heat rejected to the atmosphere. The difference between these areas, the area* between the lines $T_{2}$ and $T_{1}$, represents the work done by the Carnot cycle. The ratio of the work done to the heat added is the Carnot efficiency $E$ and is

$$
E=\frac{T_{2}-T_{1}}{T_{2}}
$$

Figure B-2 shows the deficiencies in performance of a gas turbine compared with the idealized Carnot cycle operating between the temperature

* Only for reversible processes, for which there are no losses caused by friction, etc., do areas on the temperature-entropy diagram represent heat and work. Real power plant processes can only be approximately so represented. 
ORNL-DWG 77-10430

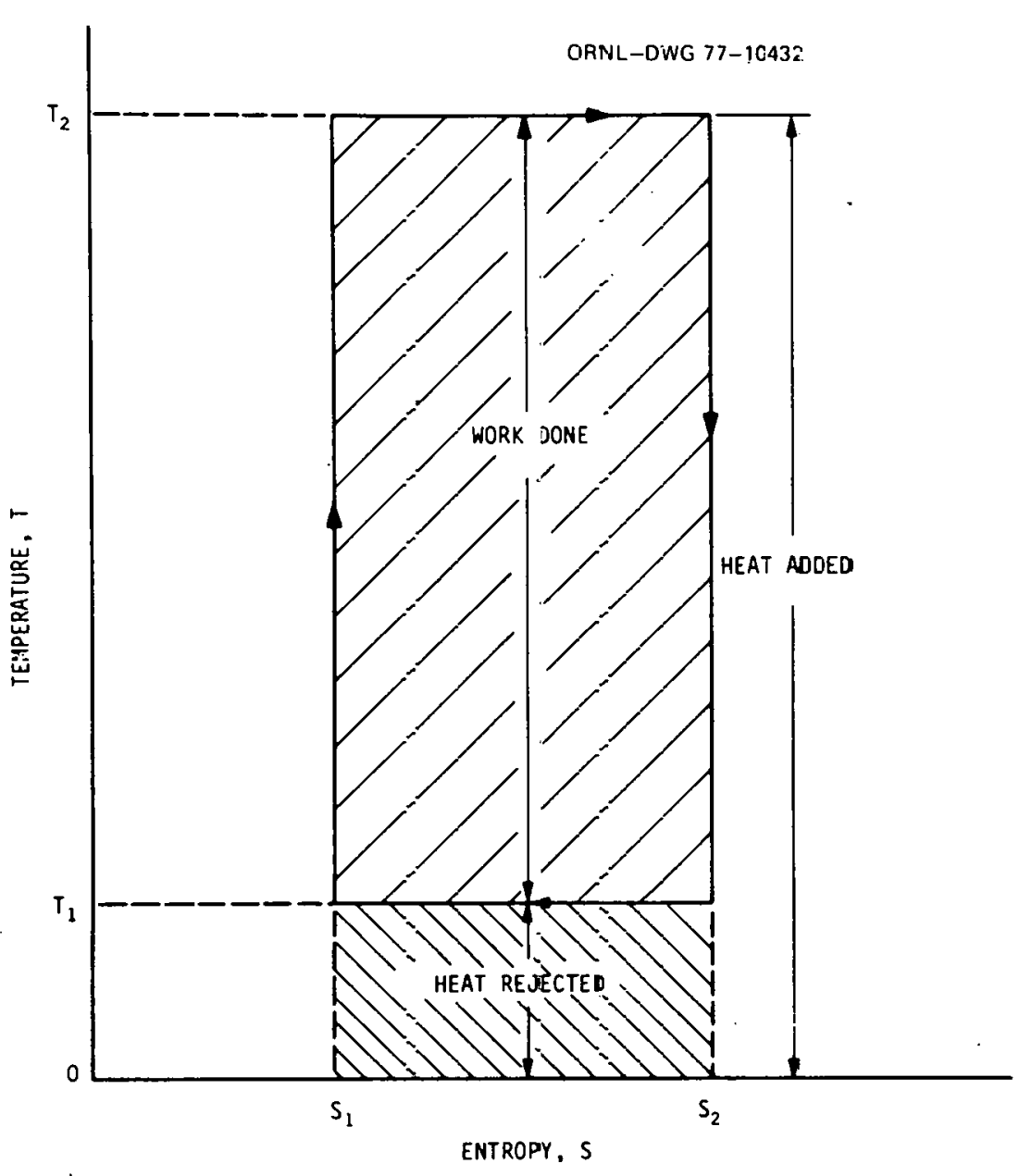

Fig. B-1. Carnot cycle.

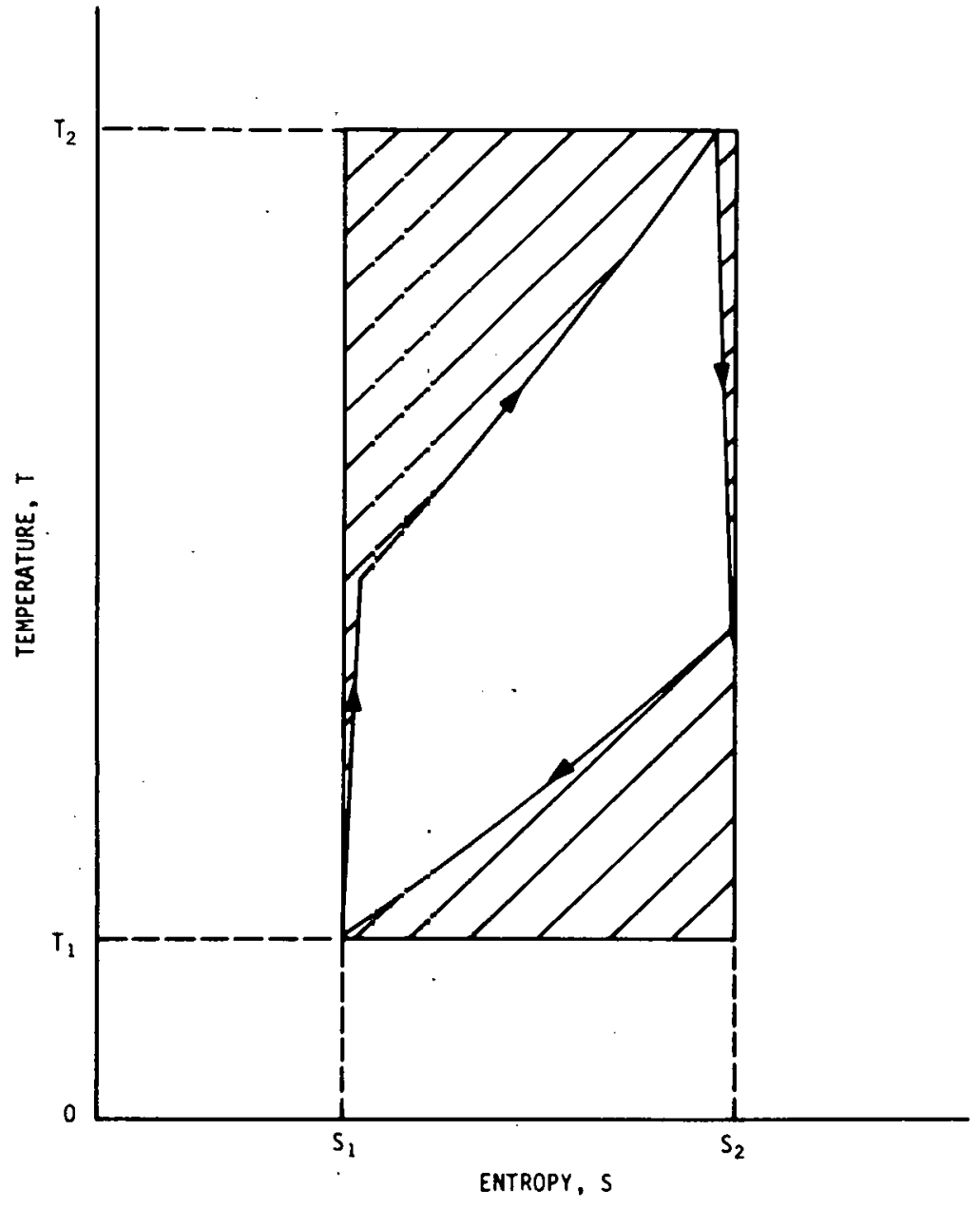

Fig. B-2. Gas turbine cycle. 
limits $T_{2}$ and $T_{1}$ in the form of the areas left outside the cycle in the region representing Carnot work.

Figures B-3 and B-4 show somewhat different arrangements of combined cycles in which some of the heat exhausted from the gas turbine is used for making steam in the steam plant. It is apparent that the diagrams of the combined cycles have somewhat less area left blank in the regions representing Carnot work and therefore may have higher thermal efficiencies than either of the separate cycles. In the cycle represented by Fig. B-3, the exhaust heat from the gas turbine is used to provide all the feedwater heat and part of the heat of evaporation. For the steam section of the plant, the remaining heat of evaporation and the superheat and reheat are provided by a heat source other than the sensible heat in the turbine exhaust - probably afterburner. In the cycle represented by Fig. B-4, the gas turbine exhaust provides all the heat required for the

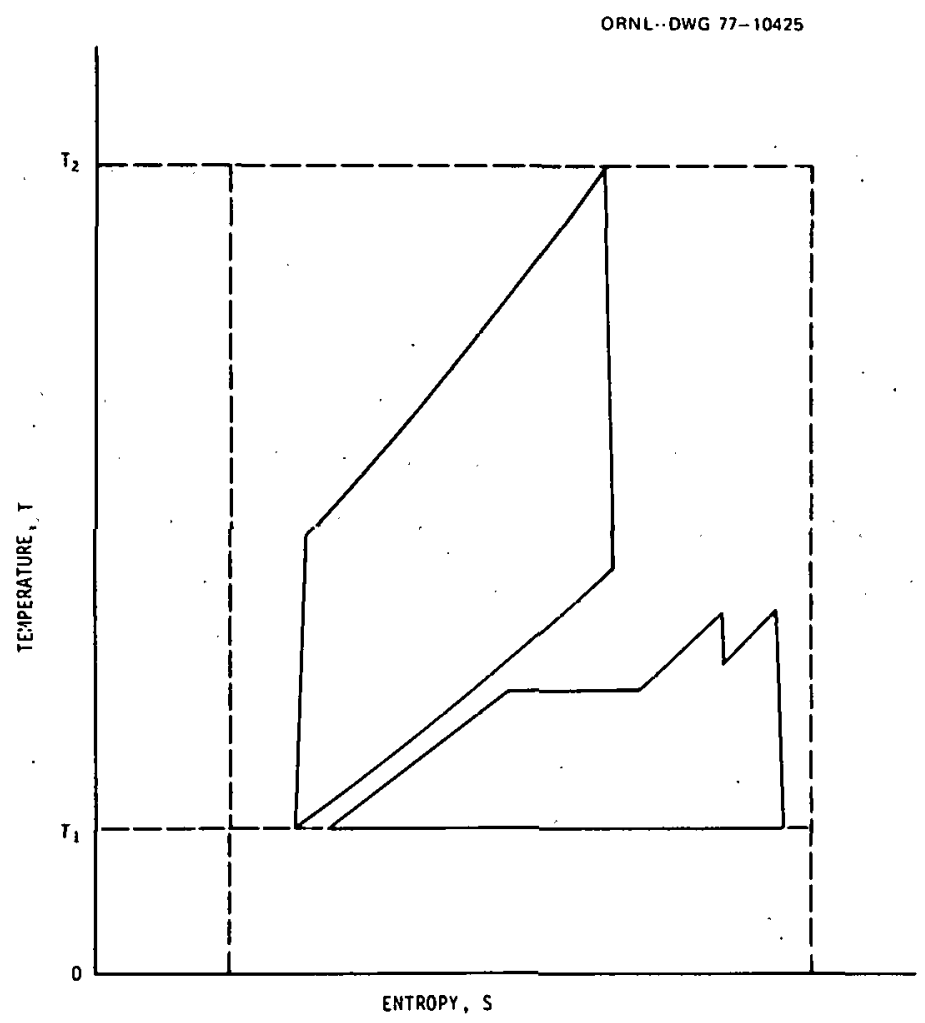

Fig. B-3. Combined cycle with the steam cycle heat requirement supplied partly by the gas turbine cycle and partly by a burner in the gao turbine cxhauot otrcam. 


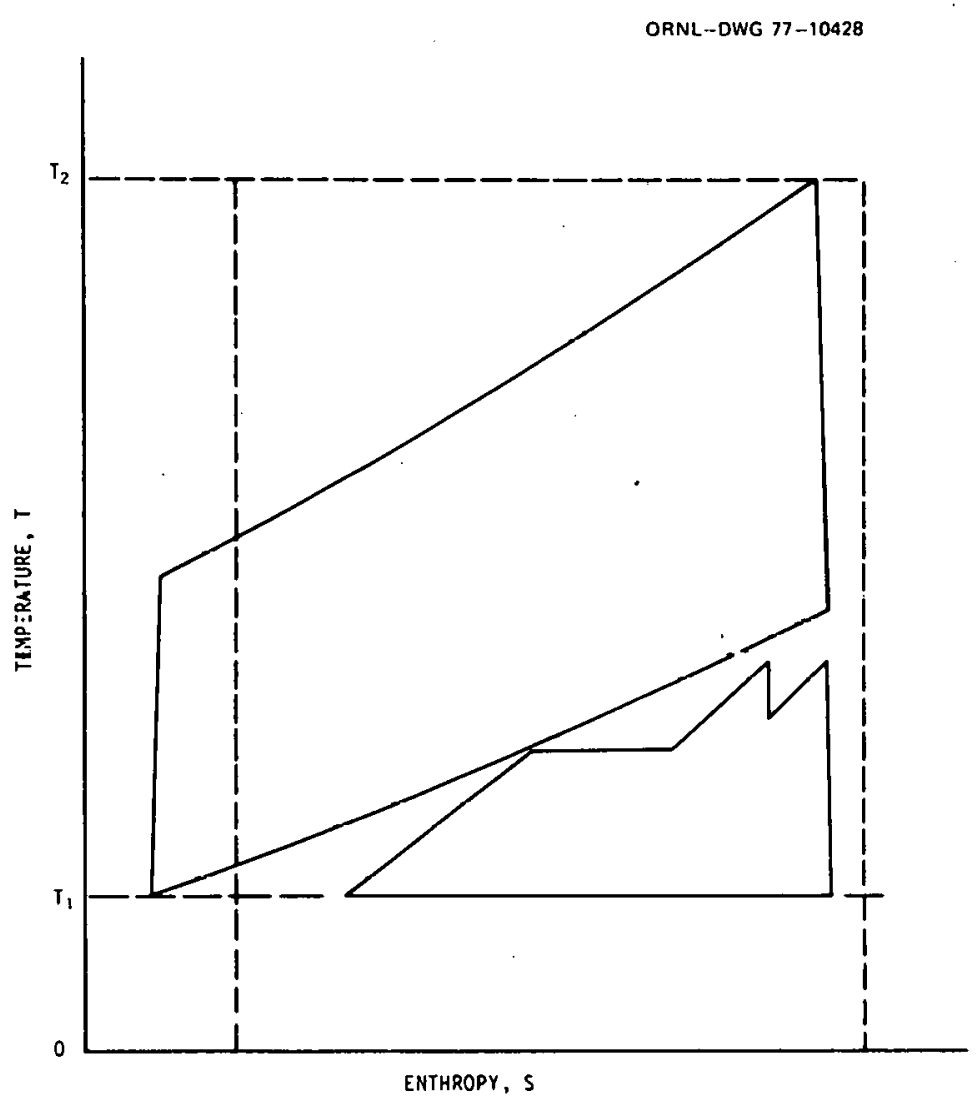

Fig. B-4. Combined cycle with the steam cycle heat requirement entirely supplied by the gas turbine cycle.

steam section of the plant. Many other combinations are possible, including the use of steam bled from the steam turbine at an intermediate pressure for feedwater heating or process application. The performance of each combination must be considered within the confines of the system application.

\section{Maximum Efficiency of a Combined Cycle} with a Fired Boiler

Consider as an example the calculated performance of a combined gas turbine-steam power cycle that consists of a refired $10 \mathrm{MPa}-538^{\circ} \mathrm{C}-538^{\circ} \mathrm{C}$ $\left(1500\right.$ psia $-1000^{\circ} \mathrm{F}-1000^{\circ} \mathrm{F}$ ) steam cycle topped with a gas turbine. The steam part of the cycle has a thermal efficiency of $40.7 \%$ and the characteristics given in Table $\mathrm{B}-1$. 
Table B-1. Steam cycle performance

\begin{tabular}{llll}
\hline & $\begin{array}{c}\text { Low-pressure } \\
\text { system }\end{array}$ & $\begin{array}{c}\text { High-pressure } \\
\text { system }\end{array}$ & Tota1 \\
\hline Evaporation pressure, $\mathrm{MPa}(\mathrm{psia})$ & $3.59(540)$ & $10(1500)$ & \\
Evaporation temperature, ${ }^{\circ} \mathrm{C}\left({ }^{\circ} \mathrm{F}\right)$ & $244(471)$ & $311(591)$ & \\
Net work, $\mathrm{kJ} / \mathrm{kg}$ & 1226 & 281 & 1508 \\
Heat added, $\mathrm{kJ} / \mathrm{kg}$ & 1295 & 2409 & 3705 \\
$\quad$ Feedwater & 942 & 343 & 1287 \\
$\quad$ Evaporation & 353 & 1318 & 1318 \\
$\quad$ Superheat & & 748 & 1101 \\
Thermal efficiency, \% & & & 40.7 \\
\hline
\end{tabular}

The gas turbine is operated at an overall temperature ratio $(\tau)$ of turbine inlet temperature to ambient temperature of 4 , which represents approximately the present gas turbine operating conditions. The average component efficiency $(\mu)$ in the gas turbine cycle is taken as $98 \%$, and the cycle pressure ratio is varied to determine the effects upon the overall cycle efficiency.

It can be seen in Table B-2 that the highest thermal efficiency for the combined cycle occurs when the gas turbine cycle is designed for maximum work. A theoretical analysis of this system shows that this result is to be expected.

The temperature-entropy (T-S) diagram of the combined cycle is shown schematically in Fig. B-5. The symbols used in the following development have the significance indicated in the figure, where $Q_{1}$ is the heat added to the gas turbine from an external source, $W_{t}$ is the work done by the gas turbine cycle, and the heat rejected from the gas turbine cycle is the sum of $Q_{3}$, the heat rejected to the atmosphere, and $Q_{2}$, the heat transferred from the gas turbine exhaust to the steam boiler. The total heat added to the steam cycle is the sum $Q$ of two quantities: $Q_{2}$, the heat from the gas turbine exhaust, and $Q_{4}$, the heat supplied from an external source. The work done by the steam cycle is $\mathrm{W}_{\mathrm{s}}$, and the heat rejected to the atmosphere from the steam cycle is $Q_{5}$. The efficiency of the combined 
Table B-2. Gas turbine and combined-cycle perfcrmarce ${ }^{a}$

\begin{tabular}{|c|c|c|c|c|c|c|c|c|}
\hline $\begin{array}{l}\text { Compressor } \\
\text { temperature } \\
\text { ratio, } \tau_{c}\end{array}$ & $\begin{array}{l}\text { Compressor } \\
\text { pressure } \\
\text { ratio, } \rho_{c}\end{array}$ & $\begin{array}{l}\text { Gas turbine } \\
\text { eff:ciency, } E_{i} \\
(\%)\end{array}$ & $\begin{array}{c}\text { Gas turbine. } \\
\text { exhanst } \\
\text { temperature, } \mathrm{T}^{\mathrm{T}} \text { exh } \\
\text { ( }^{\circ} \mathrm{C}^{-}\end{array}$ & $\begin{array}{l}\text { Gas turbine } \\
\text { work, } W_{t}\end{array}$ & $\begin{array}{c}\text { Exhaust. heat } \\
\text { to steam, } Q_{2} \\
(\mathrm{~kJ} / \mathrm{kg})\end{array}$ & $\begin{array}{l}\text { External heat } \\
\text { to steam, } Q_{4}\end{array}$ & $\begin{array}{l}\text { Combined } \\
\text { cycle work, } w\end{array}$ & $\begin{array}{l}\text { Combined cycle } \\
\text { efficiency, E } \\
(\%)\end{array}$ \\
\hline 1.56 & 3.5 & 0 & & 0 & & & & \\
\hline 1.66 & 4.1 & 4.3 & 699 & 138 & 2916 & 1022 & 1646 & 39.3 \\
\hline 1.96 & 6.6 & 14.7 & 549 & 409 & 2237 & 1468 & 1916 & 45.1 \\
\hline 2.32 & 10.5 & 21.7 & 422 & 497 & 1666 & 2039 & 2005 & 46.3 \\
\hline 2.74 & 16.8 & 23.9 & 319 & 409 & 1178 & 2527 & 1916 & 45.2 \\
\hline 3.24 & 27.0 & 13.5 & $22 z$ & 138 & 757 & 2948 & 1646 & 41.4 \\
\hline 3.44 & 31.8 & 0 & & 0 & & & & \\
\hline
\end{tabular}

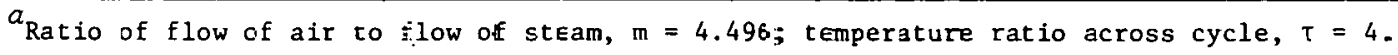




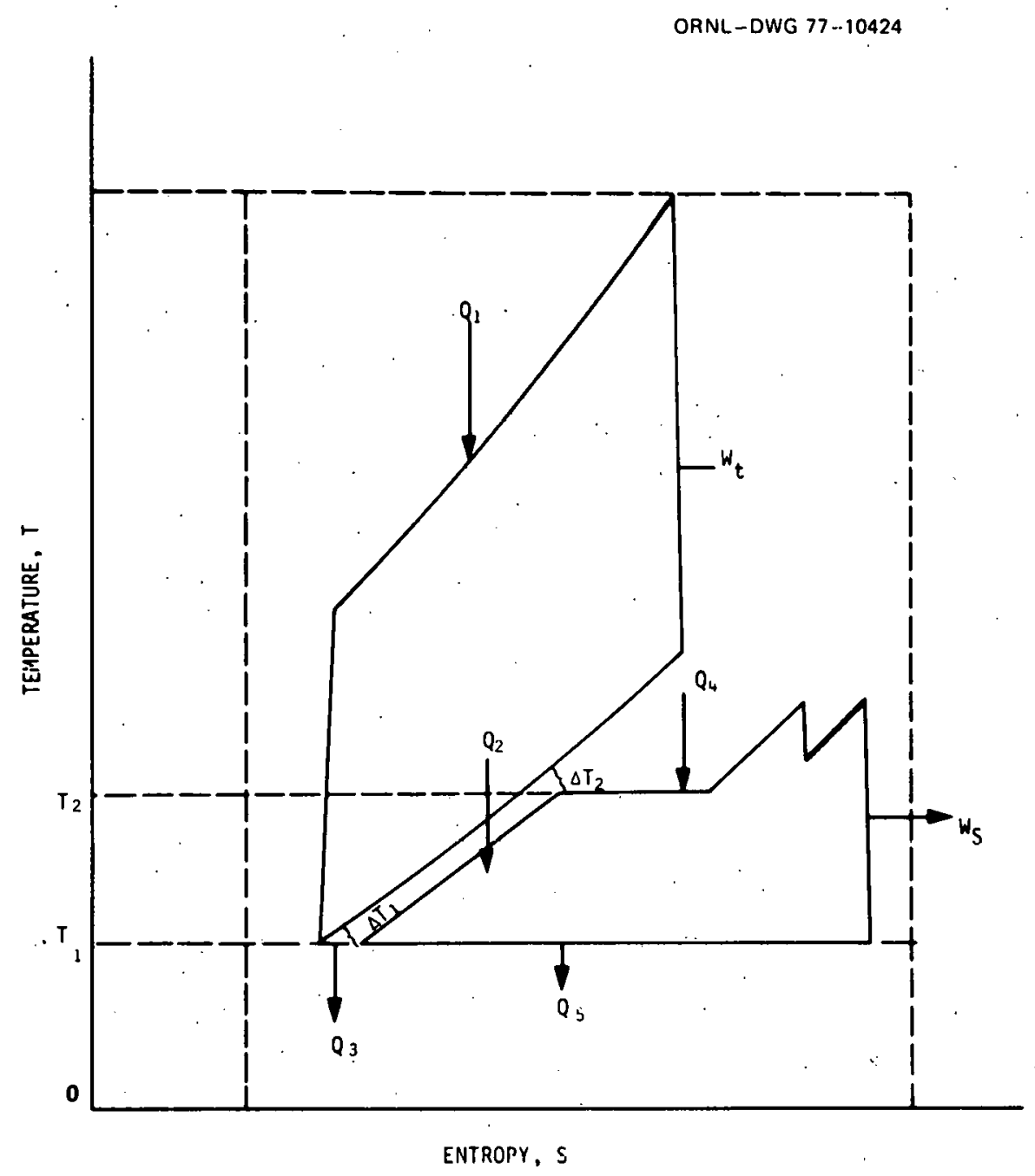

Fig. B-5. T-S diagram for a gas turbine-steam combined cycle.

cycle is given by the expression

$$
E=\frac{W_{t}+W_{s}}{Q_{1}+Q_{4}} .
$$

From the diagram,

$$
Q_{4}=Q_{-} Q_{2}
$$

From the first law of thermodynamics,

$$
\bar{Q}_{2}=\bar{Q}_{1}-W_{L}-Q_{3}
$$


Combining these expressions gives, for the efficiency,

$$
E=\frac{W_{t}+W_{s}}{W_{t}+Q+Q_{3}}
$$

The thermal efficiency of the combined cycle and the work output of the gas turbine cycle will depend on the choice of the compressor temperature ratio $\tau_{c}$, whereas the quantities, $W_{S}, Q$, and $Q_{3}$ are independent of the choice of compressor ratio. It is desired to find whether there is a choice of the compressor temperature ratio which maximizes the thermal efficiency. This condition would be expected to occur when $d E / d \tau_{c}=0$, or from Eq. (4), when

$$
\frac{d W_{t}}{d \tau_{c}}\left(Q+Q_{3}-W_{s}\right)=0
$$

Since the quantity in parentheses can never be zero (the efficiency of the steam cycle cannot be greater than unity), it is required that

$$
\frac{d W_{t}}{d \tau_{c}}=0
$$

This is the requirement for a gas turbine maximum work cycle and indicates that the maximum efficiency of the combined cycle will occur when the gas turbine cycle is designed for maximum work. The results in Table B-2 indicate that this expectation is indeed satisfied for the calculations made here.

It would be expected from consideration of the Carnot cycle that for maximum efficiency the temperature differences, $\Delta \mathrm{T}_{1}$ and $\Delta \mathrm{T}_{2}$ (see Fig. B-5), should be made as small as possible within the restraints of reasonably sized equipment as determined by considerations of heat transfer. An investigation shows that this is the case. Equation (1), for the thermal efficiency of the combined cycle, can be written

$$
E=\frac{\left[E_{t}-\left(1-E_{t}\right)\right](h / Q)\left(T_{e x h}-T_{1}\right)+E_{s}\left(T_{2}-T_{1}+\Delta T_{2}-\Delta T_{1}\right)}{\left[E_{t}-\left(1-E_{t}\right)\right](h / Q)\left(T_{e x h}-T_{1}\right)+T_{2}-T_{1}-(1-h / Q) \Delta T_{1}+\Delta T_{2}} .
$$


When this expression is differentiated with respect to the two temperature differences, the result is

$$
\begin{aligned}
& K d E=\left\{\left(1-E_{S}\right)\left[E_{t}\left(1-E_{t}\right)\right]\left(T_{\text {exh }}-T_{1}\right)-\Delta T_{1}\right\} \\
& \times d\left(\Delta T_{2}\right)+\left\{T_{2}-T_{1}-\left(1-E_{s}-h / Q\right)\left[E_{t}\left(1-E_{t}\right)\right]\right. \\
&\left.\quad\left(T_{\text {exh }}-T_{1}\right)+E_{s} \Delta T_{2}\right\} d\left(\Delta T_{1}\right),
\end{aligned}
$$

where $\mathrm{K}$ is a positive number, $\mathrm{h}$ represents the energy required to heat feedwater, and $E_{S}$ is the thermal efficiency of the steam cycle. Therefore, the efficiency of the combined cycle is highest when the two temperature differences are as low as possible and preferably equal. This result is also seen in Fig. B-6, where the maximum efficiency occurs when the mass flow ratio is adjusted to give equal values of the temperature differences.

Figures B-7 to B-9 show the effects on the thermal efficiency of changing one of the design conditions used for the calculation of the results of Table $B-2$, namely, $\tau=4$ for the overall cycle temperature ratio (turbine inlet temperature $=927^{\circ} \mathrm{C}$ ), $\mu=0.9$ for the average component efficiency of the gas turbine cycle, and $\Delta \mathrm{T}=28^{\circ} \mathrm{C}$ for the temperature difference across the feedwater heater. The results of these figures can be briefly summarized as follows:

1. The fuel rate of the combined gas turbine-steam cycle improves about $2 \%$ for a rise of $56^{\circ} \mathrm{C}$ in the turbine inlet temperature (the fuel rate for the gas turbine cycle itself improves about $7.5 \%$ for a rise of $56^{\circ} \mathrm{C}$ ).

2. The fuel rate for the combined cycle improves about $2.7 \%$ for an increase of $1 \%$ in the average component efficiency in the gas turbine cycle (the fuel rate for the gas turbine cycle itself improves about $17.7 \%$ for an increase of $1 \%$ in component efficiency).

3. The fuel rate for the combined cycle worsens by somewhat more than $2.5 \%$ for each additional $28^{\circ} \mathrm{C}$ rise in the temperature difference $(\Delta \mathrm{T})$ between the air and water in the feedwater heater. 
ORNL--EWE 77-90429A

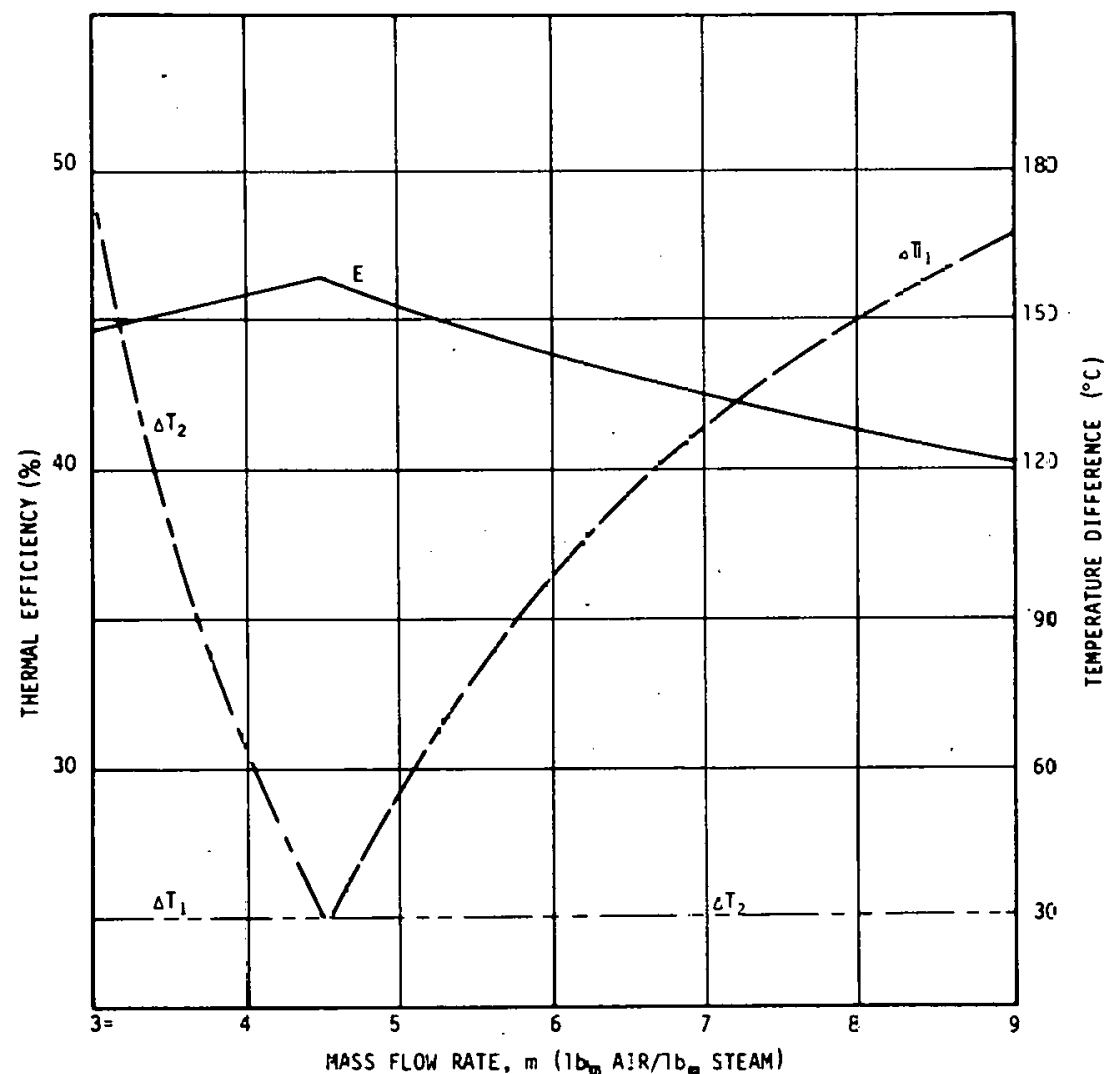

Fig. B-6. Thermal e. fficiency of conbined cycle vs mass flow rate.

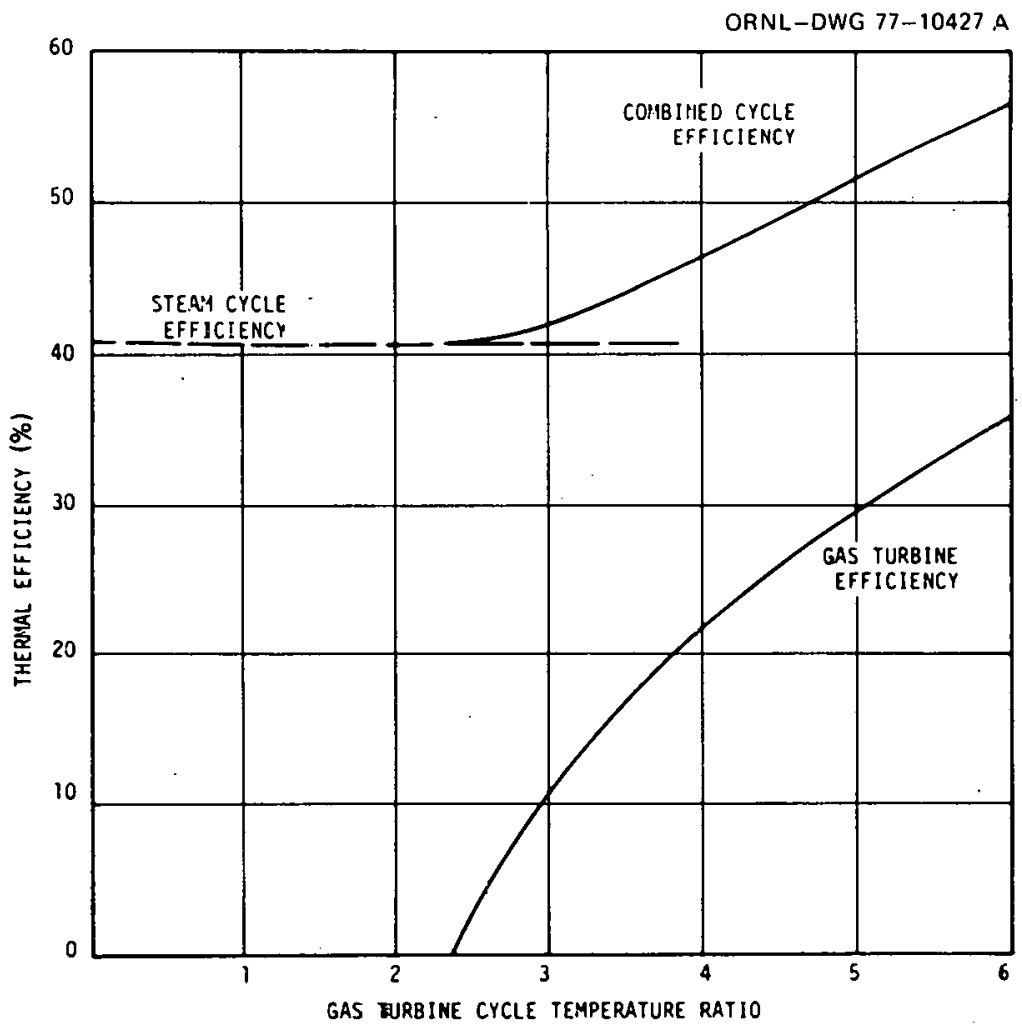

Fig. B-7. Zombined cycle thermal efficiency as a function of the gas turbine cycle temperature ratis. 


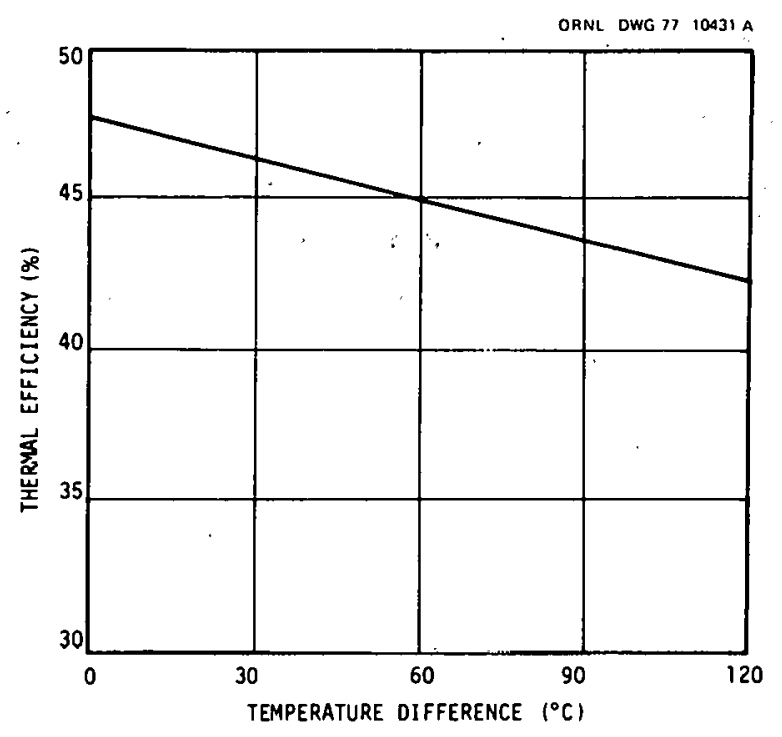

Fig. B-8. Combined cycle thermal efficiency as a function of the heat exchanger temperature difference.

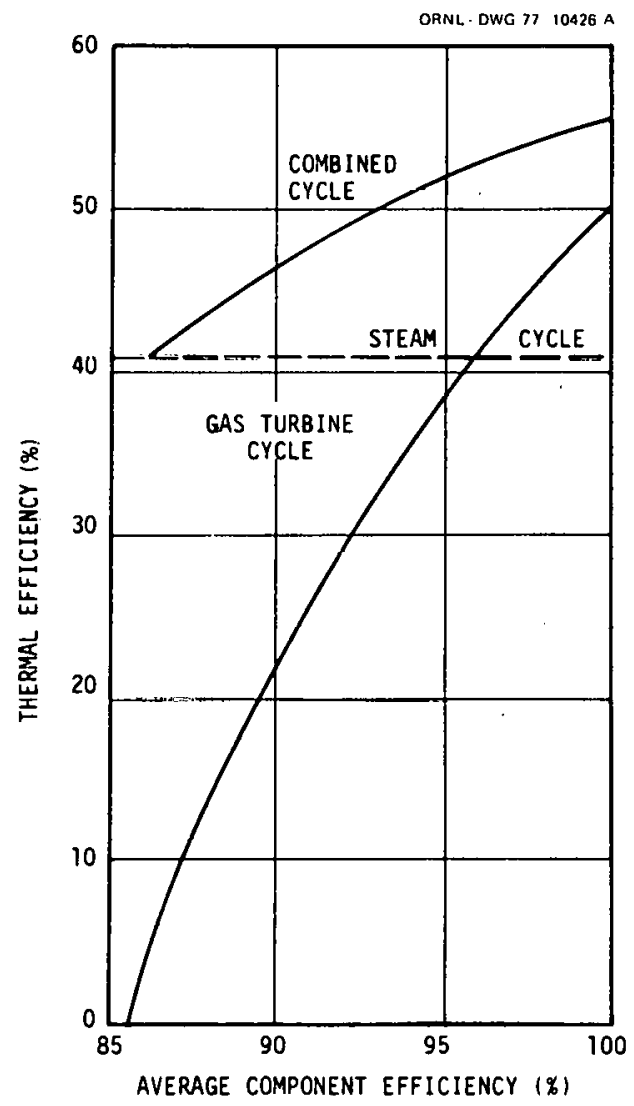

Fig. B-9. Combined cycle thermal efficiency as a function of the average gas curbine component efficiency. 
Because the efficiency and power output from the basic steam cycle are both higher than those of the gas turbine, the efficiency of the combined cycle is less dependent on changes in the gas turbine cycle than is the gas turbine cycle itself. This means also that rather large improvements in gas turbine cycle performance are needed to make significant improvements in the performance of the combined cycle. 
ORNL/TM-6252

Dist. Category UC-90f

\section{Internal Distribution}

$\begin{aligned} \text { 1. } & \text { E. C. Fox } \\ 2-6 . & \text { A. P. Fraas (consultant) } \\ 7 . & \text { T. G. Godfrey } \\ 8-11 . & \text { R. L. Graves } \\ 12-16 . & \text { R. S. Holcomb } \\ 17 . & \text { J. M. Holmes } \\ 18 . & \text { J. E. Jones, Jr. } \\ 19-28 . & \text { M. E. Lackey } \\ 29 . & \text { R. E. MacPherson } \\ 30 . & \text { L. E. McNeese } \\ 31 . & \text { T. W. Pickel }\end{aligned}$

\author{
32. J. L. Rich \\ 33. M. W. Rosenthal \\ 34. I. Spiewak \\ 35. H. E. Tramme 11 \\ 36. D. B. Trauger \\ 37. G. P. Zimmerman \\ 38. ORNL Patent office \\ 39. Central Research Library \\ 40. Document Reference Section \\ 41-42. Laboratory Records Department \\ 43. Laboratory Records, RC
}

\section{External Distribution}

44. S. Alpert, EPRI, 3412 Hillview Ave., Palo Alto, Calif. 94304

45. D. H. Archer, Westinghouse Research Laboratory, 1310 Beulah Road, Pittsburgh, Pa. 15235

46. J. T. Bartis, Planning and System Engineering, DOE Fossil Energy, MS-C-164, Germantown, Washington, D.C. 20545

47. D. H. Broadbent, National Coal Board (IEA Services Ltd.), 14/15 Lower Grosvenor Place, London, England

48. R. D. Brooks, General Electric Co., Energy Systems and Technology Division, Bldg. 2, Schenectady, N.Y. 12345

49. Robert Brookshire, Tennessee Valley Authority, 440 Commerce Union Bank Bldg., Chattanooga, Tenn. 37401

50. John Byam, Morgantown Energy Technology Center, P.0. Box 880, Morgantown, W.Va. 26505

51. N. H. Coates, The Mitre Conrp., Westgate Research Park, McLean, Va. 22101

52. A. Cohn, EPRI, 3412 Hillview Ave., Palo Alto, Calif. 94304

53. H. G. Corneil, Exxon Enterprises, Inc., 1251 Avenue of the Americas, New York, N.Y. 10020

54. Russe11 Cove11, Combustion Engineering, Inc., 1000 Prospect Hill Road, Windsor, Conn. 06095

55. E. L. Daman, Foster Wheeler Corp., 110 S. Orange Ave., Livingston, N.J. 07039

56. Shelton Ehrlich, EPRI, 3412 Hillview Ave., P.0. Box 10412, Palo Alto, Calif. 94304

57. John Eustis, DOE, Washington, D.C. 20545

58. E. C. Feher, TRW, Mail Station 01/2270, I Space Park, Redondo Beach, Calif. 90278

59. T. J. Fitzgerald, Oregon State University, Chemcial Engineering Department, Corvallis, Ore. 97331

bu. R. W. Foster-Pegy, Westinghouse Electric Corp., Gas Turbine Engine Division, P.0. Box 9175, Philadelphia, Pa. 19113 
61. Stcven Freedman, Coal Conversion and Utilization, Division of Fossil Energy Research, DOE, Washington, D.C. 20545

62. J. A. Fullam, Ingersol1-Rand Co., Process Compressor and Expanders, Turbo Products Division, Phillipsburgh, N.J. 08865

63. F. D. Gme ind1, Morgantown Energy Technology Center, P.0. Box 880, Morgantown, W.Va. 26505

64. G. H. Goff, Research and Engineering, Bechtel Corp., 50 Beale St., San Francisco, Calif. 94119

65. Jerry Golden, Tennessee Valley Authority, Knoxville Office Complex, 400 Commerce Avenue, WlOAl9, Knoxville, Tenn. 37902

66. W. B. Harrison, Southern Company Services, Inc., P.0. Box 2625, Birmingham, Ala. 35202

67. H. R. Hazard, Battelle Columbus Laboratories, 505 King Avenue, Columbus, Qhio 43201

68. T. A. Helrlek, Ellluit Cumpany, Jeannerte, Pa. 15644

69. R. C. Hoke, Exxon Research and Engineering Co., P.0. Box 8, Linden, N..I. 07036

1U. J. J. Horgan, United Technologies Corporation, P.0. Box 109, South Windsor, Conn. 06109

71. H. R. Hoy, Director, Leatherhead Laboratory, National Coal Board (BCURA), Ltd., Randalls Road, Leatherhead, Surrey, England

72. D. L. Keairns, Westinghouse Research Laboratory, 1310 Beulah Road, Pittsburgh, Pa. 15235

73. C. W. Knudson, General Electric Co., Energy Systems and Technology Division, Bldg. 2, Schenectady, N.Y. 12345

74. L. R. Lawrence, Jr., Gas Research Institute, 3424 S. State St., Chicago, I11. 60616

75. J. F. Louis, Massachusetts Institute of Technology, 77 Massachusetts Avenue, Energy Laboratory, Room 31-254, Cambridge, Mass. 02139

76. T. E. Lund, EPRI, 3412 Hillview Avenue, P.O. Box 10412, Palo Alto, Calif. 94304

77. J. J. Markowsky, American Electric Company, 2 Broadway, New York, N.Y. 10004

78. C. H. Marston, General Electric Company, 1 River Road, Schenectady, N.Y. 12345

79. M. J. Mayfield, Tennessee Valley Authority, 1020 Chestnut Street 'lower-1 I, Chattanooga, Tenn. 37401

80. J, L, Morgan, General Electric Co., l River Road, Srhenectady, N.Y. 12345

81. Seymour Moskowitz, Curtiss-Wright Corp., One Passaic Street, Wood-Ridge, N.J. 07075

82. Abolhassan Nazemi, The Mitre Corp./METREK Division, Westgate Research Park, McLean, Va. 22101

83. W. T. Newberry, Tennessee Valley Authority, 1020 Chestnut Street Tower-II, Chat tanooga, Tenn. 37401

84. Kent Philips, Combustion Power Company, Inc., Mem1n Park, Calif. 94025

85. Jim Powe11, Brookhaven National Laboratory, Department of Applied Science, Upton, N.Y. 11973

86. Lynn Rubow, Gilbert Associates, P.0. Box 1498, Reading, Pa. 19603 
87. L. I. Shure, NASA-Lewis Research Center, 21000 Brookpark Road, Cleveland, Ohio 44135

88. Lyle Six, AiResearch Mfg. Co., 402 South 36th Street, Phoenix, Ariz. 85034

89. J. W. Smith, Babcock and Wilcox, 20 South Van Buren Avenue, Barberton, Ohio 44203

90. E. V. Somers, Westinghouse Electric Corp., Research and Development Center, Churchill Boro, Pittsburgh, Pa. 15235

91. A. M. Squires, Department of Chemical Engineering, Virginia Polytechnic Institute, Blackburg, Va.

92. Beno Sternlicht, Mechanical Technology, Inc., 968 Albany Shaker Road, Latham, N.Y. 12110

93-97. A. S. Thompson, P.0. Box 118, Sperryville, Va. 22740

98. R. H. Tourin, Program Director, New York State ERDA, 230 Park Avenue, New York, N.Y. 10017

99. J. G. Vlahakis, DOE, Washington, D.C. 20545

100. G. E. Voelker, Fossil Fuel Utilization, DOE Fossil Energy, M.S.-E-178, Germantown, Washington, D.C. 20545

101. J. F. Weinhold, Tennessee Valley Authority, 1345 Commerce Union Bank Bldg., Chattanooga, Tenn. 37401

102. G. C. Weth, Fossil Fuel Utilization, DOE Fossil Energy, MS-E178, Germantown, Washington, D.C. 20545

103. D. M. Willyoung, General Electric Co., I River Road, Schenectady, N.Y. 12345

104. H. W. Withers, Tennessee Valley Authority, 1020 Chestnut Street, Tower-II, Chattanooga, Tenn. 37401

105. F. A. Zenz, F. A. Zenz, Inc., P.0. Box 205, Garrison, N.Y. 10524

106. W. Zimmerman, General Electric Co., Advanced Energy Program, Evendale, Ohio 45215

107. Office of Assistant Manager for Energy Research and Development DOE, ORO, Oak Ridge, Tenn. 37830

108-324. Given diśtribution as shown in DOE/TIC-4500 under category UC-90f 